\title{
Comparison of forest road characteristics between forest stewardship properties and non-forest stewardship properties in central West Virginia
}

Matthew A. Provencher

West Virginia University

Follow this and additional works at: https://researchrepository.wvu.edu/etd

\section{Recommended Citation}

Provencher, Matthew A., "Comparison of forest road characteristics between forest stewardship properties and non-forest stewardship properties in central West Virginia" (2004). Graduate Theses, Dissertations, and Problem Reports. 1987.

https://researchrepository.wvu.edu/etd/1987

This Thesis is protected by copyright and/or related rights. It has been brought to you by the The Research Repository @ WVU with permission from the rights-holder(s). You are free to use this Thesis in any way that is permitted by the copyright and related rights legislation that applies to your use. For other uses you must obtain permission from the rights-holder(s) directly, unless additional rights are indicated by a Creative Commons license in the record and/ or on the work itself. This Thesis has been accepted for inclusion in WVU Graduate Theses, Dissertations, and Problem Reports collection by an authorized administrator of The Research Repository @ WVU. For more information, please contact researchrepository@mail.wvu.edu. 
Comparison of Forest Road Characteristics Between Forest Stewardship Properties and Non-Forest Stewardship Properties in Central West Virginia

Matthew A. Provencher

Thesis submitted to the College of Agriculture Forestry and Consumer Sciences at West Virginia University in partial fulfillment for the requirements for the degree of

\author{
Master of Science \\ In \\ Forest Management \\ David McGill, Ph.D, Chair \\ Darrell Dean, Ph.D \\ Todd Petty, Ph.D \\ Davis College of Agriculture, Forestry and Consumer Sciences \\ Division of Forestry
}

\author{
Morgantown, West Virginia \\ 2004
}

Keywords: Forest Stewardship Program, Forest Roads, Timber Harvesting, Best Management Practices 


\begin{abstract}
Comparison of Forest Road Characteristics Forest Stewardship Properties and NonForest Stewardship Properties
\end{abstract}

\begin{abstract}
Matthew A. Provencher
Eight non-stewardship properties and seven stewardship properties were visited and measurements were taken to determine whether or not differences exist between these two property types. Twenty dependent variables relating to residual vegetation, forest road characteristics, erosion and certain best management practices were used to characterize timber harvesting operations that had been conducted on these property types. With the exception of road density and waterbar implementation, analysis of these dependent variables failed to detect any statistical differences among property types. Results suggest that stewardship landowners may also have a wider range of harvest objectives as well as use a wider diversity of BMPs. 81\% of BMP practices encountered other than waterbars were observed on stewardship properties. A correlation exists between industry land and road density. Reach capacity and excess reach capacity are two new metrics of road efficiency that warrant further research.
\end{abstract}




\section{Acknowledgements}

There are many people to whom I owe a great deal of gratitude for aiding me in completing this research. I would first like to thank the United States Forest Service for providing the necessary funding for this project. I would also like to thank the West Virginia Division of Forestry for their assistance, especially Deputy State Forester Ralph Glover and Webster County Service Forester Mayford Lake. Ralph Glover was instrumental in aiding my search for timber harvests within the study area by providing me with the necessary notification forms, and Mayford Lake was helpful in assisting my search for landowner phone numbers as well as increasing my knowledge of the harvesting practices in the region.

I would also like to thank the faculty and staff here at West Virginia University, especially my committee members - David McGill, Darrell Dean, and Todd Petty for

their aid, guidance and expertise during this project. Also deserving thanks are Shawn Grushecky, whose assistance and guidance was invaluable to me, and George Seidel, for his assistance with statistics.

Finally, I would like to thank my family for their unwavering financial and emotional support throughout these college years. Without you, none of this would have been possible. Your support has not gone unnoticed, even if I have not always expressed it. No matter where life takes me next, home will always be where the heart is. 


\section{Table of Contents}

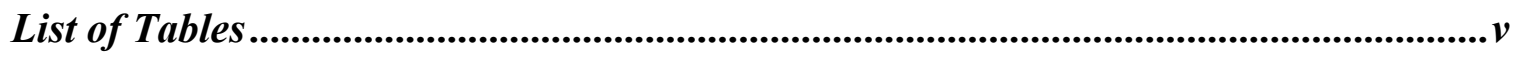

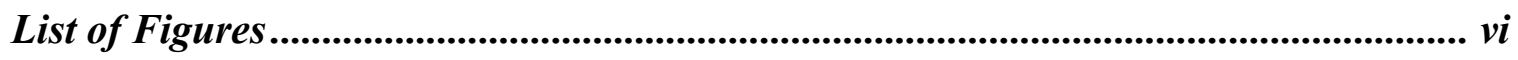

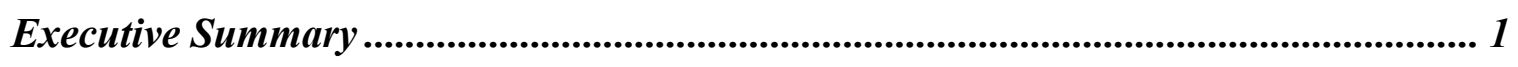

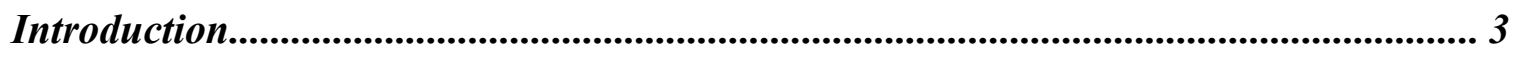

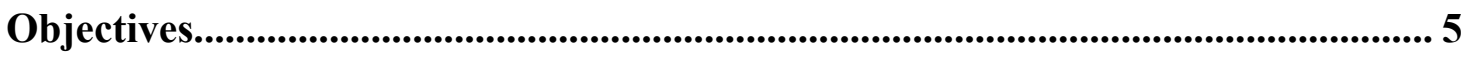

Literature Review........................................................................................................ 7

Forest Roads and Sedimentation ..................................................................... 7

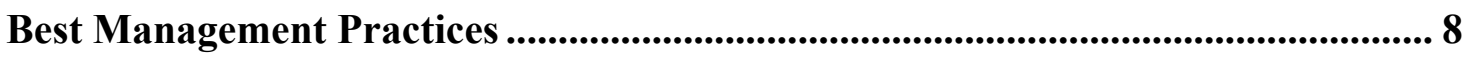

The Forest Stewardship Program .......................................................................... 11

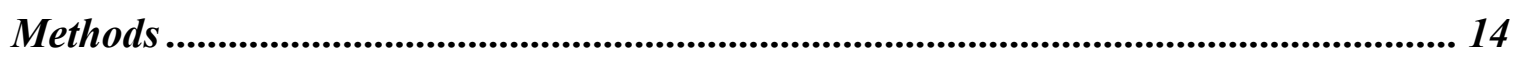

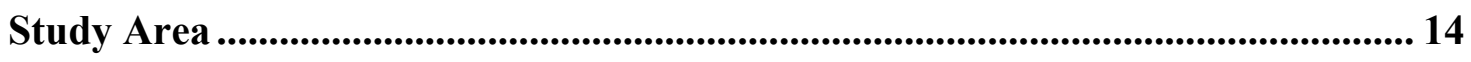

Study Sites...................................................................................................................... 17

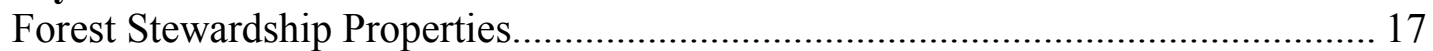

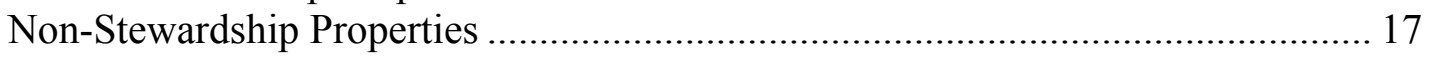

Road System Measurements ...................................................................... 18

Residual Stand Measurements............................................................................................ 22

Data Analysis ................................................................................................................. 23

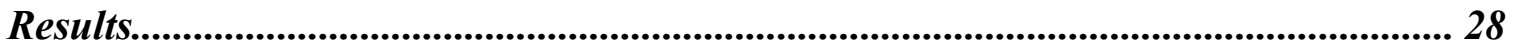

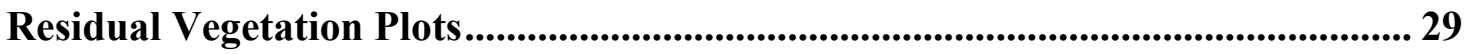

Skid Road Attributes ................................................................................................. 30

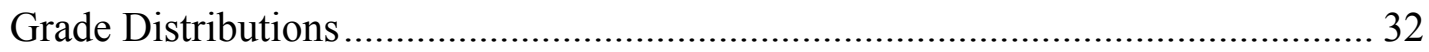

Erosion and BMP Compliance .................................................................................... 36

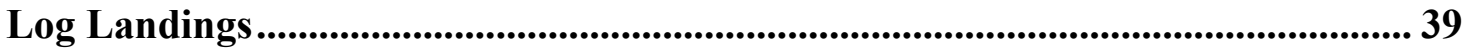

Landowner Objectives and Forester Involvement................................................. 41

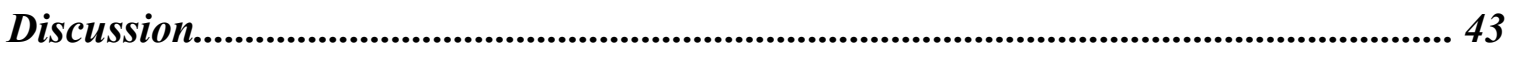

Reach and Excess Reach Capacity ......................................................................... 47

Management Implications............................................................................................. 49

References ............................................................................................................... 52

Appendix A: Skid road layout maps for sites used in this study .................................... 56

Appendix B: Reach capacity maps for sites used in this study .................................... 72

Appendix C: Excess reach capacity maps for sites used in this study ........................... 88

Appendix D: Grade distribution graphs......................................................................... 104 


\section{List of Tables}

Table 1: Twenty dependent variables and the associated analytical test.....................24

Table 2: Residual stand data by property type and site ………....................................30

Table 3: Primary calculated skid road attributes for property types by site ..................34

Table 4: Primary measured skid road attributes for property types by site ...................35

Table 5: Erosion categories and the percent of sites in which that category was

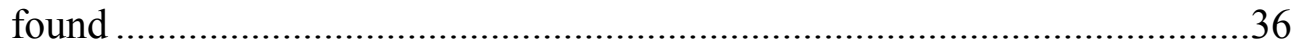

Table 6: BMP significance values by grade class.......................................................38

Table 7: Erosion and BMP compliance measures by property type and site. Erosion and rutting are a categorical value that ranges from 1 (lowest) to 5 (highest). WB Compliance $15 \%$ corresponds to the BMP compliance percentage on road segments with a grade greater than or equal to $15 \%$. Vegetation percent is the percent of the road segment ocularly estimated to be vegetated. This is only for road segments $15 \%$ or greater

Table 8: Log landing data separated by site and property type. Erosion values are categorical, ranging from 1 (lowest) to 5 (highest) Only one landing was observed on each site

Table 9: Level of forester involvement on the timber sales involved in this study .....42

Table 10: Pooled road attributes of this study compared to a previous study in West Virginia

Table 11: Erosion categories and the associated percentage of sites in which the category occurred. 


\section{List of Figures}

Figure 1: Map of the 35 major watersheds in West Virginia. The Elk River watershed is highlighted in yellow ........................................................ 14

Figure 2: Map of the Elk River watershed. The Upper Elk River watershed is highlighted in purple. County names are labeled....

Figure 3: Map detailing the locations of the five watersheds included within the study area

Figure 4: Profile view of a hypothetical road. Characters about the road line are the filenames that would be entered into the GPS Unit. Characters below are the grade of the hypothetical road

Figure 5: Map showing the location of the 15 study sites used in this study 28

Figure 6: Road Density by site and property type. The sites are put in ascending order from lowest road density to highest.

Figure 7: Relationship between road density and reach capacity 32

Figure 8: Right skewed grade distribution with a positive skewness value

Figure 9: Left skewed grade distribution with a negative skewness value. 33

Figure 10: BMP compliance trends for the property types. 38

Figure 11. 1998-2003 summer precipitation data for West Virginia. 


\section{Executive Summary}

The Forest Stewardship Program is a forest management oriented program that offers private woodland owners written guidance and financial assistance to protect and improve the timber, wildlife, soils, water, recreation and aesthetic values of their forest. Any non-industrial private forest (NIPF) landowner who owns between 10-1,000 acres is eligible to apply to the program, with exceptions granted for landowners who own up to 5,000 acres. West Virginia accounts for almost $9 \%$ of the $(9,878,000$ acres $)$ of the total acreage owned by NIPF in the Northeastern area, and 6.5\% (596,294 acres) of the total acreage enrolled in the FSP. The FSP is federally funded, but administered by the state forester with the assistance of a State Stewardship Committee.

Eight non-FSP properties and seven FSP properties were examined to determine whether or not physical differences existed between the two. Specifically, measurements were made to assess erosion on harvest road systems, characterize the harvest road systems, assess the quality and implementation of best management practices on roads and landings, evaluate the post harvest stand structure, and evaluate reach and excess reach capacity as road planning metrics and learning tools. Twenty dependent variables were analyzed during the course of this study. BMPs observed in this study included culverts, turnouts, broad based dips, and waterbars.

The concepts of reach and excess reach capacity are two new measures of sufficiency and efficiency have the potential to be very useful in the road planning process. Reach capacity is defined as the percentage of the tract covered by a zone of specified distance, measured perpendicular to the road and completely surrounding the road. Excess reach capacity is a measure of road efficiency and is the total area of all possible road overlaps expressed as a percentage of the reach capacity (Dean 2003).

With the exceptions of road density $(p=0.0001)$ and BMP compliance $(p=0.0005)$, analysis of these dependent variables failed to detect any statistical differences among property types. Mean road density was higher on non-FSP properties $(247 \mathrm{ft} / \mathrm{ac})$ than on FSP properties (193 ft/ac). A close look at the data reveals this result may be an effect of industry land versus NIPF land rather than FSP versus non-FSP. Mean road density $(p=0.03)$ was higher on forest industry land $(262 \mathrm{ft} / \mathrm{ac})$ than on NIPF land $(211 \mathrm{ft} / \mathrm{ac})$. A total of five sites owned by forest industry were measured in this study, four of which were non-FSP properties. Differences in BMP compliance rates may be the due the FSP landowner's desire to better access their property. FSP landowners lived closer to their property than their non-FSP counterparts, and expressed desires to use their land for a variety of recreational or other personal use opportunities. Reach capacity and excess reach capacity could prove useful as planning tools when the required information is available in digital format, and warrant further research.

It is evident that forest industry land had an effect in this study. This effect was not anticipated at the start of this study. The area in which this study took place is vastly industrial, with almost $80 \%$ of the harvested acreage within the study area owned by 
forest industry. If possible, future studies may want to exclude industrial lands, and focus on NIPF lands.

One of the goals of the FSP is to grant landowners access to natural resource professionals, who write a management plan based on the landowners' desired objectives. This, however, may be the only contact that the landowner has with this professional. A follow up system might help to increase the usefulness of the FSP by ensuring that natural resource professionals are also involved in any timber sale or other management activity that FSP landowners might undertake. 


\section{Introduction}

Water quality has been an important environmental issue in the United States for decades, and much effort has been spent to improve the condition and quality of our waterways during this time. In the late 60 's and early 70 's, the environmental condition of the nation's waters was poor. Record fish kills were reported, and bacteria levels were hundreds of times the safe limit in some waterbodies (Moyers 2002). During this era, Congress passed the Federal Water Pollution Control Act in 1965. As amendments followed in 1972, 1977, and 1987, the law was commonly referred to as the Clean Water Act (CWA).

The 1972 amendments distinguish between two types of water pollution: point and nonpoint sources; forestry activities fall under nonpoint sources of pollution. Point source pollution can be traced to a particular point source, such as a pipe while nonpoint sources are less discrete. Sections 208, 319, and 404 all deal with nonpoint sources of pollution. Section 208 of the 1972 amendment requires states to develop watershed level water quality management plans. Section 404 , added in 1977 , regulates the discharge of pollutants into waterbodies. The 1977 amendments also added or extended deadlines for industry to meet best available technology standards for certain toxins (Muskie 1978). Section 319 of the 1987 amendments required states to directly address waterbodies affected by nonpoint sources of pollution (Hawks et al. 1993; Ice et al. 1997).

To control nonpoint source pollution, the Environmental Protection Agency (EPA) further developed the concept of best management practices (BMPs) to control nonpoint sources of pollution (Lynch and Corbett 1990; Ice et al. 1997), identifying specific practices after the 1987 amendments to the CWA were passed (Lynch and 
Corbett 1990). BMPs can be defined as practices determined by a state to be effective in reducing the amount of nonpoint source pollution to levels that are compatible with water quality goals (Lynch and Corbett 1999).

Identifying and reducing nonpoint source pollution is crucial to the goal of sustainable natural resource management. West Virginia is arguably one of the most important regions in the eastern United States in terms of watershed values as its mountains are the "birthplace" of rivers; consequently the goal of sustainable natural resource management is of critical importance. In a study conducted in 1990 by the West Virginia Division of Forestry (WVDOF), timber harvesting ranked sixth in the state among the major causes of sediment from nonpoint sources, with coal mining, state roads agriculture, oil and gas drilling, and construction ranked as having a greater impact (Whipkey 1990). It has been proven in several studies that the act of felling trees itself does not lead to erosion or sedimentation, but logging roads and landings constructed to extract and transport the timber can lead to increased erosion (Kochenderfer 1970; Patric 1976; Corbett et al. 1978; Swift 1984; Lockaby and Rummer 1996).

Legislative efforts to control nonpoint source pollution in West Virginia have been established. The West Virginia Logging Sediment Control Act (LSCA) (WV Code 19-1B), which took effect in 1992, regulates logging and associated nonpoint source pollution. The law requires that a certified logger must be present on an active logging job each day the job is active, and must have training in tree felling safety and personal safety equipment, first aid, and silvicultural best management practices. It also requires the use of BMPs on logging jobs, and gives the West Virginia Division of Forestry the power to enforce these rules (WVDOF 2002). 
Planning, maintenance, and retirement of road systems used to harvest timber are important to minimize sedimentation to streams, rivers, and lakes (Egan 1999). Implementation of BMPs on forest access roads has been proven effective in reducing erosion in West Virginia (Kochenderfer et al. 1997), and forester involvement in a timber sale has been proven to increase BMP implementation rates (Egan 1999). Participants in the West Virginia Forest Stewardship Program (FSP) were more likely to employ a forester in their timber sales which suggests a "greater commitment to forest stewardship among participants in the Forest Stewardship Program" (Egan et al. 2001).

Additional measures of road efficiency might also be useful when planning new road systems, or assessing current road systems. Currently, road density is the most common measure of efficiency discussed. The concepts of reach and excess reach capacity are two new measures of efficiency have the potential to be very useful in the road planning process. Reach capacity is defined as the percentage of the tract covered by a zone of specified distance, measured perpendicular to the road and completely surrounding the road. Excess reach capacity is a measure of road efficiency and is the total area of all possible road overlaps expressed as a percentage of the reach capacity (Dean 2003).

\section{Objectives}

The FSP is designed fundamentally as an educational and technical assistance program, where private forest landowners are "educated" through a planning process that results in a schedule of potential management activities for their properties. The purpose of this study is to assess whether or not there are differences in certain physical postharvest characteristics between Forest Stewardship (FSP) properties and non-Forest 
Stewardship (non-FSP) properties. In this study, we investigate the difference in timber harvest road systems and stand structure between these two property types. To this end, our objectives are to:

1. Assess erosion on harvest road systems.

2. Characterize harvest road systems.

3. Evaluate post-harvest stand structure.

4. Assess the quality and implementation of BMPs on roads and landings.

5. Evaluate reach and excess reach capacity as road planning metrics and learning tools.

Meeting these objectives will determine if differences exist between harvest road systems and stand structure for these property types. The information collected will give more insight into erosion from timber harvests in forested watersheds in West Virginia. Evaluating reach and excess reach capacity will help to determine their usefulness in the road planning process, which may help to reduce road density on future timber harvesting jobs. 


\section{Literature Review}

\section{Forest Roads and Sedimentation}

The harvesting of trees alone, that is the physical act of felling trees, aside from roads and landings does not cause soil erosion. Rather it is the transportation networks, the roads and landings, that are the primary source of sedimentation resulting from forestry activities (Kochenderfer; 1970; Patric 1976; Corbett et al.1978; Swift 1984; Lockaby and Rummer 1996). Kochenderfer (1977) found that roads and landings in skidder-logged areas in West Virginia accounted for about $10.3 \%$ of the area with road densities averaging $267 \mathrm{ft} \mathrm{ac}^{-1}$.

Forest access roads are places of exposed, often compacted mineral soil. This makes them an excellent source for overland water movement. Using the water erosion prediction project model, Elliot and Tysdal (1999) found that road length, gradient and soil types are the primary factors in road erosion. Other studies have shown that sediment production from forest roads increases with increasing slope and length (Luce and Black 1999). Other factors may also lead to an increase in erosion, such as removing vegetation from the side of roads, or soil texture, with coarser soils producing less sediment than finer soils. It has also been shown that older roads produce less sediment than newer roads (Luce and Black 1999).

Timber harvesting consists of two processes: 1) cutting trees and 2) transporting merchantable logs to wood-using mills. Improper construction and maintenance of road systems can lead to sedimentation in streams. No impacts to surface water, ground water or stream turbidity have been associated with timber felling; however water quality deteriorates when felling is combined with improper logging or road construction 
(Corbett et al. 1978; Lockaby and Rummer 1996). Potential increases in soil erosion occur when transporting logs on skid roads installed to access the harvesting area. Road building and subsequent traffic create exposed soils which are subject to the erosive forces of rain and runoff (Kochenderfer 1970) as infiltration rates on these areas are well below those of undisturbed forest soils (Patric 1976).

Planning is an important step in reducing erosion from forest roads. Planning forest roads may be one of the most underutilized steps in the timber harvesting process. Planning a road system often will lead to fewer roads, as well as lead to better protection of water resources. It has been shown that planning forest roads can reduce the area of a harvest in skid roads by as much as 40\% in West Virginia (Kochenderfer 1970). Egan (1999) states three concepts to consider when planning road systems: momentum, avoidance and the universal soil loss equation. Momentum, the water's mass multiplied by velocity, should be at a minimum if erosion is to be reduced, something BMPs can aid greatly in accomplishing. Avoidance means simply being aware of any surface water and avoiding it whenever possible. Finally, consider the elements of the universal soil loss equation $\mathrm{A}=\mathrm{R} * \mathrm{~K} * \mathrm{LS} * \mathrm{C} * \mathrm{P}$ where:

$\mathrm{A}=$ average annual soil loss from a soil surface.

$\mathrm{R}=$ rainfall and runoff erosivity index

$\mathrm{K}=$ soil erodibility factor

$\mathrm{LS}=$ topographic factor

$\mathrm{C}=$ vegetative cover management factor

$\mathrm{P}=$ conservation practice index

Applying the above concepts when planning a road system will aid in reducing erosion.

\section{Best Management Practices}

The concept of Best Management Practices was first developed by the Environmental Protection Agency (EPA) to help deal with the problem of nonpoint 
source pollution (Lynch and Corbett 1990; Ice et al. 1997). Since 1997, all states have had programs to mitigate nonpoint source pollution originating from silvicultural activities, although not all of these programs are regulatory (Ice et al. 1997). Some programs lack methods to regulate enforcement or punishment for noncompliance. Reports concerning BMPs can generally be put into 3 categories: 1) those detailing different state programs, 2) surveys assessing BMP compliance, and 3) studies assessing BMP effectiveness.

Lickwar et al. (1990) detailed the BMP programs of 13 southern states. At that time, all of the states had programs to mitigate silvicultural nonpoint source pollution, although virtually all were non-regulatory. Florida was the only state that required use of BMPs in some instances, such as in or near wetlands. In the 12 northeastern states in 1992, two had no silvicultural nonpoint source pollution programs, although BMPs were recommended through water quality or other environmental laws and regulations (Irland and Connors 1994). By 1997, all 50 states had some sort of program designed to control silvicultural nonpoint source pollution (Ice et al. 1997). In 2000, a survey of state forestry agencies found all responding states had developed BMPs for silviculture (Edwards and Stuart 2002). Forty-two of the 48 responding states have implementation programs specifically designed to increase BMP use, usually through education, training, tours, and demonstrations. Thirty states have monitoring programs in place to assess compliance (Edwards and Stuart 2002).

BMPs reduce erosion because they 1) slow the movement of water and 2) move water off the road to the forest floor where it can more easily infiltrate the soil. Impacts of timber harvesting to water quality involves increases in temperature through increased 
solar insolation, sediment deposition through elevated erosion, while dissolved nutrient concentrations may increase or decrease due to management activities and increased erosion. Effective use of BMPs can minimize or prevent these impacts. On the Leading Ridge Experimental Watersheds in Pennsylvania, slight increases in water temperature, sediment levels, nitrate, and potassium concentrations were observed after a timber harvest; however, BMPs were effective in controlling these when compared to a control watershed where no BMPs were implemented (Lynch et al. 1985). The increases did not exceed drinking water standards on the site where BMPs were implemented. Another study conducted by Lynch and Corbett (1990) on the Leading Ridge Experimental Watersheds found that BMPs were effective in controlling stream turbidity and temperature. Temperature only increased where trees were cut along the bank of the stream. Changes in stream chemistry were seen, however. BMPs were also effective on the Hubbard Brook Experimental Forest in New Hampshire (Martin and Hornbeck 1994), and in West Virginia (Kochenderfer et al. 1997). In West Virginia sediment levels did increase, but remained within accepted levels. Rapid decrease in sediment levels was noted in subsequent years, after the completion of harvesting. No change to $\mathrm{pH}$ was noted, however increases in some nutrient concentrations were observed. Wynn et al. (2000) conducted a study in which two watersheds were clearcut, only one with BMPs. Both the BMP watershed and the control watershed showed few changes with respect to sediment loading or nutrient concentrations. The watershed without BMPs had both increased sediment and nutrient concentrations. A study in South Carolina (Adams et al. 1995) used a different approach, assessing BMP effectiveness using a rapid bioassessment approach designed by the US Environmental Protection Agency. This 
approach uses stream habitat assessment and benthic macroinvertebrate bioassessment to gauge nonpoint source pollution on individual timber harvests. Results showed this method to be expensive, and recommended that BMP compliance checks be done by qualified foresters, which would lead to equally effective, but less expensive compliance surveys.

An effective method to assess BMP compliance is needed for states whose programs are regulatory. Although methods for assessing compliance can vary, most are very similar. Brynn and Clausen (1991) completed a post-harvest assessment of Vermont's acceptable management practices, synonymous with best management practices. Low compliance rates were found for soil erosion control practices on truck and skid roads, but compliance rates were high for protective strip maintenance and stream avoidance. Overall, few water quality impacts were observed. Briggs et al. (1998) in Maine, and Egan et al. (1998) in West Virginia used methods similar to Brynn and Clausen. In Maine, compliance rates for BMPs ranged from as low as $25 \%$ to as high as $100 \%$. In West Virginia compliance rates increased significantly between 1991 and 1996 for BMPs used in the comparison study.

One of the benefits of landowner assistance programs, such as the Forest Stewardship Program, is the education of landowners on forestry practices, erosion and sedimentation, and BMPs. There is evidence to suggest that participation in these programs will lead to higher BMP compliance rates (Egan et al. 2001).

\section{The Forest Stewardship Program}

The Forest Stewardship Program (FSP) is designed to develop a stewardship plan based on the desired values of each individual landowner (Jennings 2003). The United 
States Forest Service periodically releases a status report of the FSP. The last report, released in 2001, gives the 10-year history of the program, including acres enrolled and dollars spent on the Program. According to the report (USDA 2001), Congress allotted \$32 million for the FSP in 2001, \$11 million of which will be used in the Northeastern area, which includes West Virginia. West Virginia added 44,061 acres to the Program in the fiscal year 2000 , accounting for over $5 \%$ of the total additions to the Program in the 20 state Northeastern area. West Virginia has a total of 596,294 acres enrolled in the Program, accounting for $6.5 \%$ of the total acres enrolled in the Northeastern area.

A study completed by Frances et al. (1997) in South Carolina attempted to assess landowner attitudes towards the FSP. Timber was the main objective for most landowners, with wildlife a preferred secondary objective. They found that landowners had four main reasons for joining the Program: cost-share dollars received, professional assistance, concern for the future, and the encouragement of multiple use. Most of the landowners were male and over 40 , with $96 \%$ having a high school diploma. The results of this study are similar to those found by a 5-year assessment of the Program by Egan et al. (2001) in West Virginia. The average age was a 57-year old male, and the two most common practices recommended in the plans were stand improvement and harvesting, respectively. Jennings (2003), completed a 10-year assessment of the Program in West Virginia and found that the average person was a 62 -year old male, and the two most common recommended practices were stand improvement and wildlife habitat improvement, respectively, with timber harvesting ranking third.

Very little work has been done to assess if there are any differences between stewardship properties and non-stewardship properties. Egan (2001) suggested that 
participants in the Forest Stewardship Program are different from general forest

landowners. FSP landowners are less likely to be motivated by income, less likely to engage in diameter limit harvesting. They were also more likely to employ logging contracts and foresters in their timber sales. Previous research by Egan (1999) has shown that forester involvement will increase BMP compliance rates. 


\section{Methods}

\section{Study Area}

The Elk River watershed is one of 35 major watersheds in West Virginia (Figure 1). The area encompassed by the watershed is a major recreational area for people both in and out of state. The watershed, especially in the upper and middle reaches, is characterized by breathtaking mountains vistas, cool clear streams, and is home to some of the best coldwater fishing in the state. The upper and middle reaches of the watershed are also relatively free of some of the impacts that affect other watersheds in the state, such as coal mining and oil and gas drilling, although these are present (Lilly, D. pers. Comm. July 2003). Timber is an important resource in the watershed, with the vast majority of the watershed being forested.

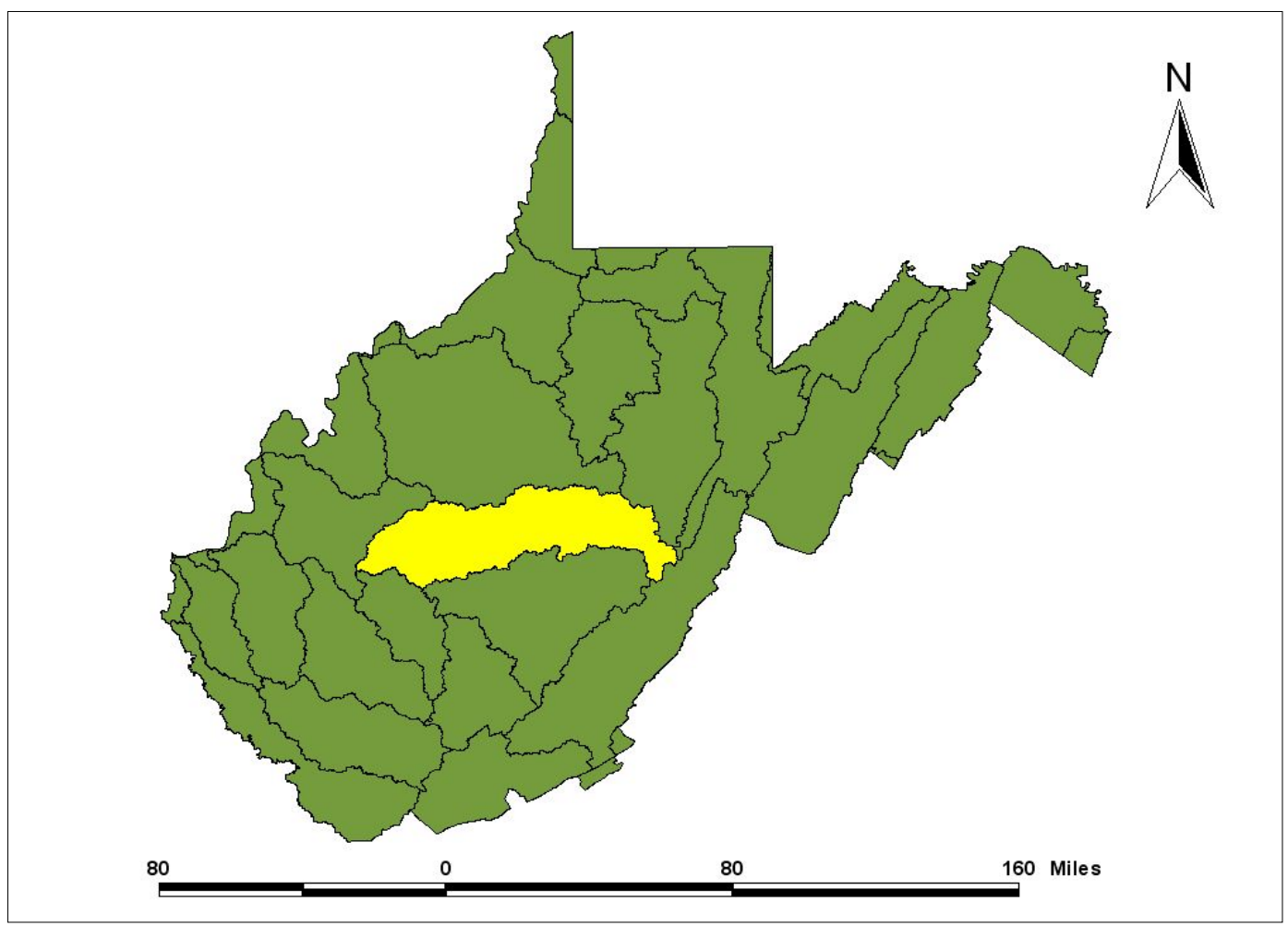

Figure 1. Map of the 35 major watersheds in West Virginia. The Elk River watershed is highlighted in yellow. 
The Upper Elk River watershed is an 11-digit hydrologic unit code (HUC) watershed within the larger 8-digit HUC Elk River watershed. The HUC is a method used by the United States Geological Survey (USGS) to delineate large watersheds. The watershed lies within parts of Randolph, Webster and Pocahontas Counties (Figure 2).

Originally, the study was to take place only in the Upper Elk River watershed. However, to increase the available number of harvests on properties that had a Forest Stewardship Plan implemented, the Holly River, Elk River 1, Laurel Creek, and Birch River watersheds were added to the study area. These watersheds are all 11-digit HUC watersheds; still, they are in the larger Elk River 8-digit HUC watershed, and their inclusion expanded the study area to include portions of Braxton and Nicholas Counties (Figure 3).

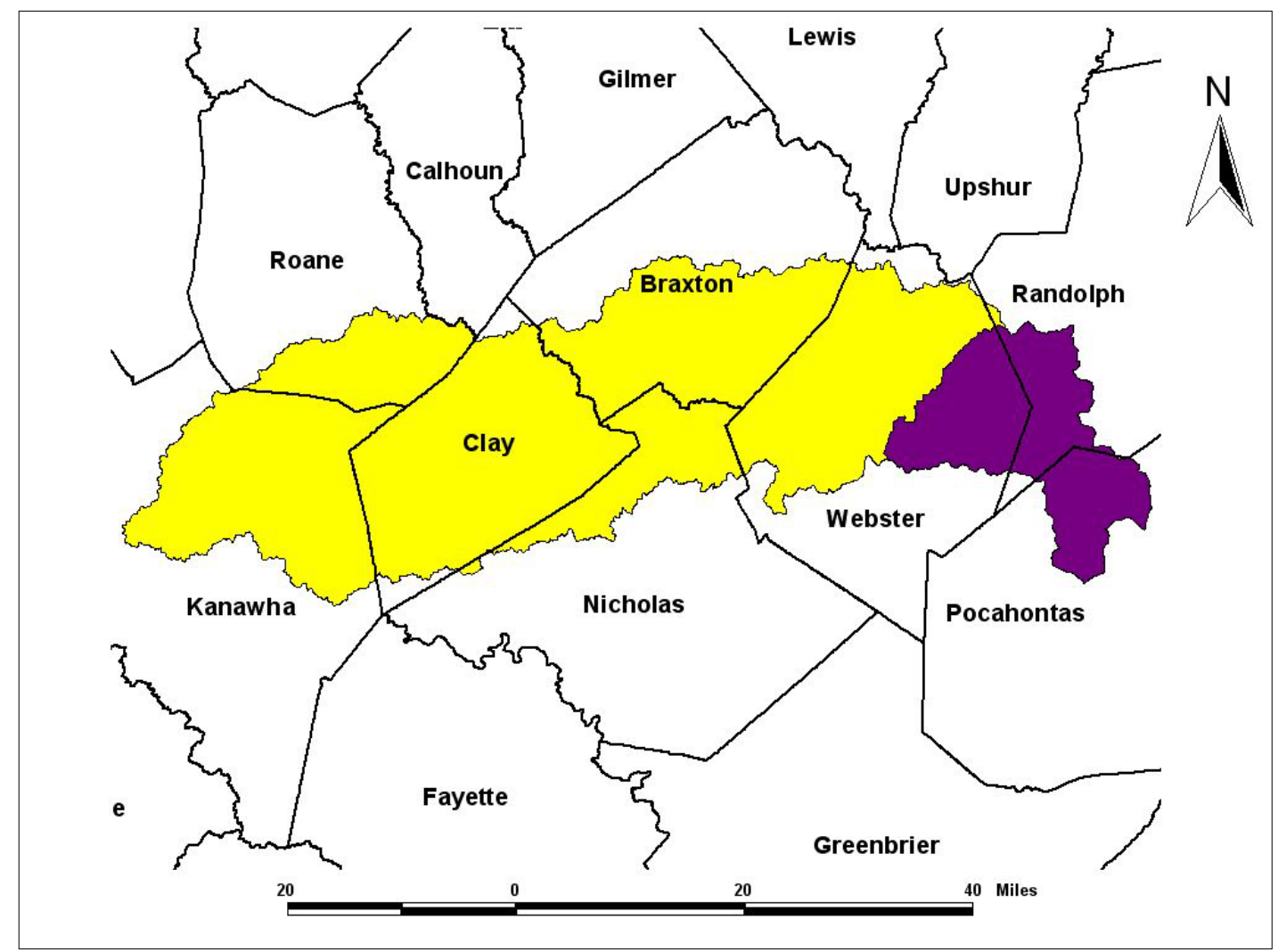

Figure 2. Map of the Elk River watershed. The Upper Elk River watershed is highlighted in purple. County names are labeled. 
These five watersheds are similar in many respects. Surface rocks throughout the watersheds are sedimentary in origin. Much of it is from the Paleozoic era or, more specifically, the Pennsylvanian periods, along with some others. They are heavily forested; characterized by steep, mountainous terrain with abundant ephemeral, intermittent, and permanent streams. The soils in the watersheds are also similar, with Gilpin associations, formed from siltstone, sandstone and shale, or Dekalb associations, created from mostly sandstone, dominating the area. These soils are characterized by steep terrain, moderately well drained or well drained, usually on mountainsides or foothills (USDA NRCS 1998).

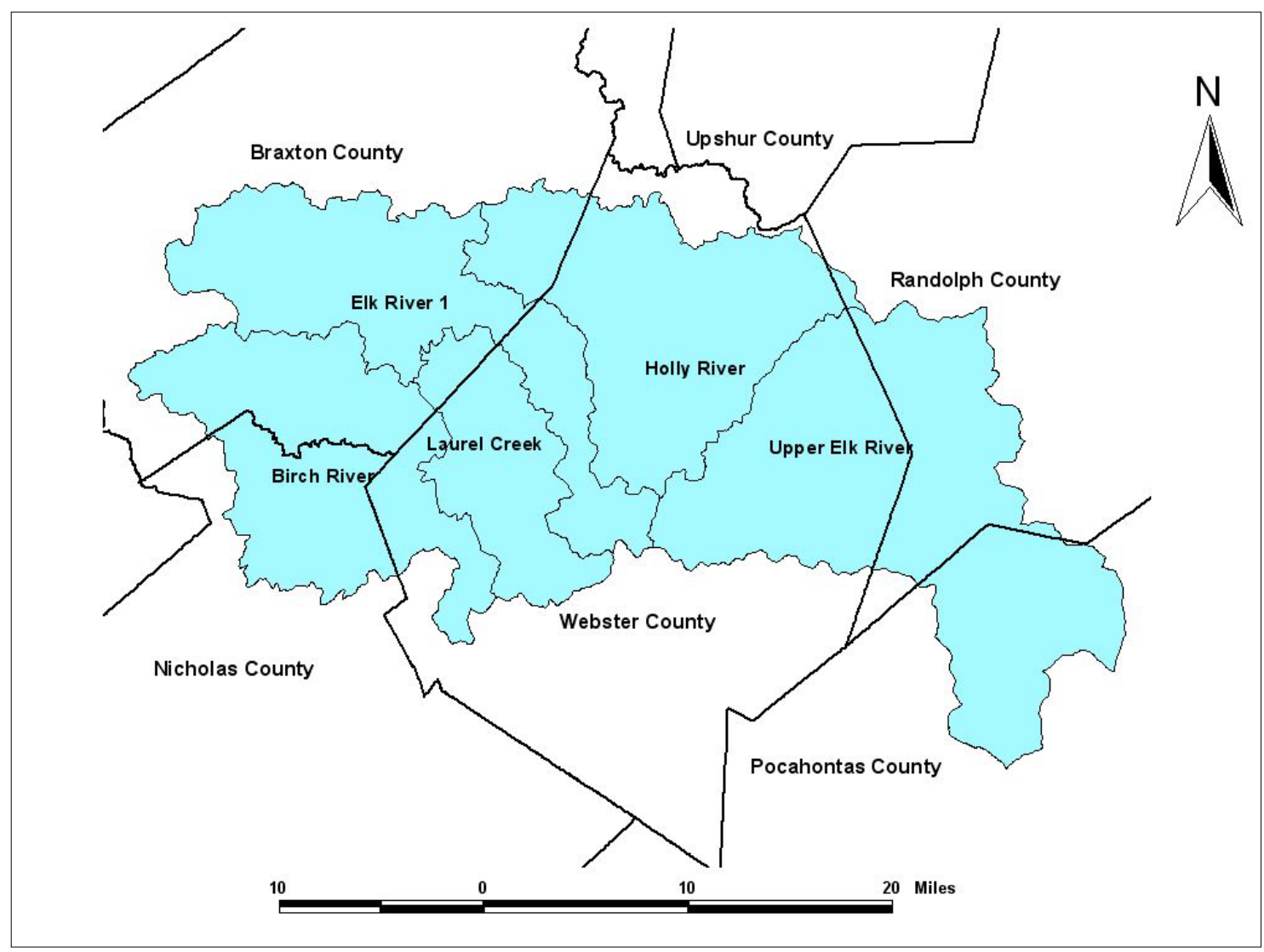

Figure 3. Map detailing the locations of the five watersheds included within the study area. 


\section{Study Sites}

\section{$\underline{\text { Forest Stewardship Properties }}$}

Forest Stewardship plans were collected from local county offices. All property locations were digitized into ArcView 3.2. One hundred and two properties with a FSP plan were located within the study area. Conversations with local foresters and internet searches were used to locate as many phone numbers as possible. Fifty-six landowners were contacted, or $55 \%$ of the target population. Reasons for non-contact include phone numbers that could not be located, wrong or disconnected numbers, or numbers otherwise not in service. Questions were asked of these 56 landowners to ascertain whether a commercial timber harvest had occurred on their property within a five-year period (1998-2002), and if they would participate in this study. Nine landowners had a commercial timber harvest within the five-year period, and all gave permission for their land to be used for this study.

\section{Non-Stewardship Properties}

Timbering operation notification forms were collected from the West Virginia Division of Forestry office in Guthrie, WV in May of 2003. All notification forms filed between January 1998 and April 2002 within the study area and having clear maps of the timber sale locations were collected.

The location of the landing for each harvest was digitized and imported into ArcView 3.2, with all information on the notification form entered into an attribute table. Attribute data included contact information for the landowner and timber owner, the agent or forester for landowner and/or timber owner, the logging company name, the town and county where the harvest was located, the year and acres to be harvested, 
nearest streams, notification number, and location of the harvest. A total of 355 harvests were digitized and incorporated into the GIS. These harvests were assigned a random number, and nine sites, corresponding to the number of FSP sites available, were chosen, starting with the lowest random number. Phone calls were made to landowners to ask permission to use their land for this study. Where permission was denied, or where the landowner could not be contacted, the next site on the list was selected. Care was made to ensure that a specific landowner and a specific logging company were only used once in this study. These selection procedures resulted in a total of 16 harvests ( 8 stewardship, 8 non-stewardship) for sampling in this study.

\section{Road System Measurements}

Data collection was completed on 14 sites during the summer months, JuneAugust 2003. One remaining site was completed during the fall months (October 2003November 2003). At each site, data was collected to characterize the condition of the haul (where applicable) and skid roads, landings, and the residual stand.

Most distances and all grades were measured using an Opti-Logic $(\subset$ 100LH Laser Rangefinder. In this paper, "grade" refers to percent slope of a road or landings, and "slope" refers to the general topographic lay of the land within each individual site. Distances were measured to the nearest foot, and grades were measured in percent slope. Lengths, widths and heights at intensive segments were measured to the nearest tenth of a foot using a Spencer Products Original Logger's Tape.

Landings served as the starting point at each site. Landing area was estimated by using the product of length and width. The grade of the landing was measured in two perpendicular directions, with maximum grade recorded. Often, it was difficult to 
determine if a landing had been seeded. Landing vegetation was assumed to be from seed, and was visually estimated to the nearest $10 \%$. The width, length, and height of the largest slash pile were also recorded. These were measured with the laser rangefinder, unless it was not possible to do so. In this case, these were measured using a 100-foot nylon tape. Height, the distance from the ground to the top of the slash pile was measured with the 100-foot nylon tape, unless the slash pile was not safe to climb. In the case of the latter, the height was visually estimated. The number of skid roads entering the landing was recorded, and it was noted whether or not they were outsloped coming into the landing, or if some water diversion structure was present to prevent water and sediment from the road entering the landing. Finally, assessments were made regarding the location of the landing with respect to streams and filter strips, and to the presence of trash, fuel, or lubricants related to the logging job. A filter strip, or streamside management zone is a no cut or light cut area adjacent to stream where no roads or landings should be placed. The WVDOF specifications are 100 feet from each side of a permanent or intermittent stream, and 25 feet for an ephemeral stream.

Skid and haul road systems were measured following the landing assessment. For the purposes of this study, only primary skid roads were measured, which were defined as skid roads that had been cut into the bank with a dozer or skidder blade. Where possible, data collection on a skid road began on the side closest to the landing. Data on skid road attributes were collected by "grade segments", contiguous sections of road with an equal grade. Length and grade of these segments were measured, and any BMPs were noted. BMPs in this study included waterbars, broad-based dips, turnouts, culverts and inside ditches. BMP functionality and quality (the degree to which the BMP was constructed to 
specifications) were also recorded. Functionality was assumed if all of the water was diverted (in cases where it was possible to observe water/BMP interaction), or if the structure was up to specification and did not appear damaged. A BMP was considered not functional if any part of it failed. A BMP could be diverting most water and sediment, but if any passed through the BMP and continued down the road surface, the BMP was considered nonfunctional. A BMP was considered up to specification if it met the standards set in the West Virginia Division of Forestry BMP Handbook (WVDOF 2002). Permanent waterbars are recommended on skidroads that are retired, or no longer in use. When assessing compliance, the spacing recommendations for waterbars were used, even if an alternative practice was used as a substitute for a waterbar. A visual estimate of the percent of the road segment vegetated was recorded to the nearest $10 \%$, however it was difficult to know if seeding had occurred as recommended by the BMP Handbook, or if the vegetation was natural. The starting point of every segment was recorded using a Trimble Geoexplorer 3 handheld GPS receiver. The GPS file name reflected the skid road number, segment and segment grade. For example, segment 3 of skid road 2, with a grade of +8.0 would have a file name S2S3-8 (Figure 4).

Intensive measurements were taken on every third grade segment, and included most severe erosion type, average road width, greatest cut height, and amount of rutting. Erosion type was recorded based on a five-category classification system modified from de Belle (1971) as discussed by Brynn and Clausen (1991). The erosion categories recorded were: (1) none or sheet erosion (minute rills present), (2) rills (up to 6 inches), (3) initial gully (6-12 inches), (4) marked gully (12-24 inches), (5), advanced gully (24+ inches). Where a gully was present, average length and width were measured, and an 
approximate percent of the road surface with gully erosion present was visually estimated. Ruts were measured with the same classification system, with depth of rut replacing erosion. Average road width measurements were taken at least in 2 separate places within the segment. For longer road segments, or segments with large variation in width, more than 2 measurements were taken.

Type of crossing, crossing angle, flow obstruction, and evidence of sedimentation were recorded for all permanent stream crossings. In some instances, it was not possible to determine how the stream was crossed (bridge, culvert) because the structure was removed. Similarly in these instances, it was not evident whether stream flow had been obstructed by the structure at the time of harvest. Type of crossing and flow obstruction were not recorded in this instance, however other data were still recorded.

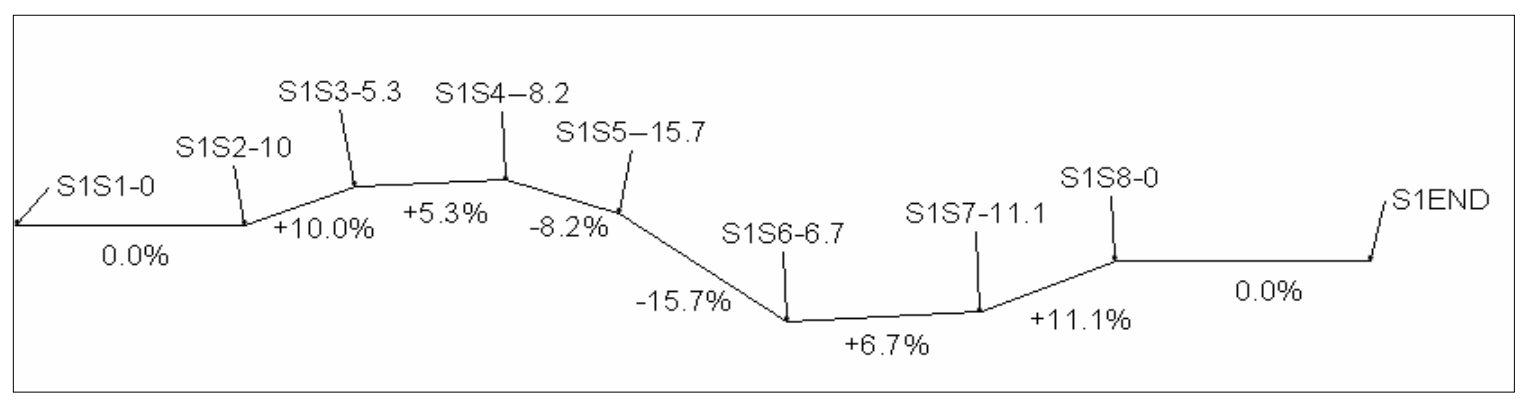

Figure 4. Profile view of a hypothetical road. Characters about the road line are the filenames that would be entered into the GPS Unit. Characters below are the grade of the hypothetical road.

Haul roads were assessed in the same manner as skid roads. A haul road was measured only if it was used as part of the timber harvest we were studying. Haul roads in use for another timber harvest, county roads, or roads otherwise open to the public were not included in this study. 


\section{Residual Stand Measurements}

Tree calipers were used to measure most trees and stumps to the nearest tenth of an inch. All trees down to a 2-inch diameter at breast height (DBH) were measured. If a tree was too large to be measured using the caliper, the Logger's tape was used. If a stump was too large for the calipers, a Lufkin executive diameter tape was used for measurement. Stumps were measured at both the maximum and minimum width, and the average of the two was taken to obtain the diameter. Residual stand data were gathered throughout the harvest area in a systematic manner, using 0.10 -acre circular plots. A residual plot was taken at a 90-degree angle from the top of the cutslope or the toe of the fillslope, in alternating fashion, at the leading edge of the third road segment. Subsequent plots were then taken at the leading edge of every sixth segment thereafter. Original methodology called for plots to be taken every sixth segment, but during pre-study testing it was discovered that roads might frequently be too short, and not yield any residual tree plots. The rule to put a plot in at the third segment was implemented to increase the possible number of plots taken. The slope (cut or fill) that the first plot was taken on in a harvest was randomly chosen by a coin flip, and each plot alternated thereafter. In some instances, due to inadequate distances between roads or harvest boundaries, a plot could not be placed. In this case, the opposite slope was used. The next residual plot taken after this would again be taken on the opposite slope. In the case where there were adverse conditions on both slopes, no residual plot was taken. Standing trees and stumps were measured on the 0.10 -acre plots. Species, DBH and crown class were recorded for all standing live trees. Diameter and species were recorded for all stumps found within the plots. 


\section{Data Analysis}

For dependent variables that had multiple observations at the site level, an analysis of variance procedure was used to investigate differences that might exist between the two property types. This model was of the form:

$$
\begin{gathered}
y_{j}=\mu+\alpha_{i}+\alpha_{i}\left(\theta_{j}\right)+\varepsilon_{i j k} \\
\text { Where: } y_{i}=\text { response variable at the } i^{\text {th }} \text { site } \\
\mu=\text { the overall mean } \\
\alpha_{i}=\text { effect of the } i^{\text {th }} \text { level of property type } \\
\alpha_{i}(\theta j)=\text { error term, site nested within property type } \\
\varepsilon_{\mathrm{ijk}}=\text { unexplained error }
\end{gathered}
$$

For dependent variables with only one observation at the site level a two-sample $t$ -test was used. All variables were tested for significance at alpha $=0.05$. There were four categories of dependent variable types to analyze, totaling 20 different dependent variables (Table 1). Certain site attributes will be pooled regardless of property type for purposes of comparison with other studies. Stocking was determined by using the Allegheny hardwoods equation used to create the Allegheny hardwoods stocking chart (Roach 1977).

Company or forest industry land may affect the outcome of some of these tests. Previous research has shown that some attributes of forest industry land may differ in some ways from general NIPF land (Egan et al. 1998), however they were included in this study since forest industry or corporate lands make up over $30 \%$ of the total forest ownerships (in terms of acres) in the counties included in this study site (USFS 2003) and accounted for almost $79 \%$ of the acreage available for this study. 
Table 1. Twenty dependent variables and the associated analytical test.

\begin{tabular}{lcc}
\hline & ANOVA & T-TEST \\
\hline Residual Vegetation & & X \\
Stocking (\%) & & $\mathrm{X}$ \\
Basal Area ft2/ac) & & $\mathrm{X}$ \\
Quadratic Mean Diameter (in) & & \\
& & \\
Skid Roads & $\mathrm{X}$ & \\
Grade (\%) & $\mathrm{X}$ & \\
Width (ft) & $\mathrm{X}$ & \\
Length (ft) & $\mathrm{X}$ & \\
Erosion (category) & $\mathrm{X}$ & \\
Rutting (category) & & $\mathrm{X}$ \\
Density (ft/ac) & & $\mathrm{X}$ \\
Area (acres) & & $\mathrm{X}$ \\
Reach Capacity (\%) & \\
Excess Reach Capacity (\%) & & $\mathrm{X}$ \\
Skewness of Grade Distributions & & $\mathrm{X}$ \\
& & \\
BMPs & & \\
Implementation Rates (\%) & $\mathrm{X}$ & \\
Quality (category) & $\mathrm{X}$ & \\
Functionality (category) & $\mathrm{X}$ & \\
Landings & & \\
Area (acres) & & \\
Vegetation (\%) & \\
Grade (\%) & & \\
Erosion (category) & \\
\hline
\end{tabular}

Follow up phone calls were made to study participants to collect information regarding landowner objectives and level of forester involvement. Forester involvement was placed into four classes, none, low, medium or high. None meant there was no forester involved in any aspect of the timber sale. Low forester involvement meant a forester was involved in some pre-harvest aspects of the timber sale, such as marking timber. Medium forester involvement meant the forester was involved in other aspects of the timber sale, such as laying out roads in conjunction with the logger, and may have 
seen the job while it was active. A high level of forester involvement meant the forester was involved in all aspects of the timber harvest, from marking timber to checking to ensure that BMPs were implemented upon completion of the job. Although it has been shown that forester involvement may affect some aspects of the timber sale, such as BMP compliance (Egan 1999), we collected this information for potential use as a covariate.

Road grades were determined using a weighted method that took into account the length of the grade. Thus, grades that occurred on longer road sections carried more weight than grades that occurred on short segments. This was used to determine the average grade of an entire road. Grade distributions were analyzed in seven grade classes at $5 \%$ intervals. Grade class 1 included grades of $0-4.9 \%$, grade class 2 included grades from $5-9.9 \%$ and so on. Grade class 7 included all grades $\geq 30 \%$. The amount of road density in each class was used to measure the distributions. This was done by finding the percent of total road footage in each class, and multiplying that by total road density for each site. In contrast, BMP compliance was calculated for each of six grade classes. The six classes are identical to the classes used by the WVDOF (WVDOF 2002). Grade class 1 covers all grades from $0-9.9 \%$; all other grade classes are identical to the classes used for grade distributions. This was done because different a spacing is required for different slopes. BMP compliance was determined by adding up the total number of functioning BMPs (regardless of if the structure was up to WVDOF specifications), and dividing this number by the total number of BMPs recommended by the WVDOF. An LSMEANS procedure was used to look for statistical differences between the grade classes. An ANOVA model was used to determine what effect BMP compliance and grade had on erosion. For this analysis, BMP compliance was determined for each 
individual road segment. In order to determine if a segment was in compliance, it had to be at least as long as the spacing recommendations in the WVDOF handbook for that given grade. As an example, a road segment with a grade of 11 percent must be at least 80 feet long, because the WVDOF recommends a waterbar every 80 feet on an 11 percent road grade. Compliance was categorized as fully compliant, partially compliant, or noncompliant.

Maps of each study site were created using ArcView 3.2. All skid roads and landings within each site were mapped. Also, reach and excess reach capacity were calculated using ArcView 3.2. Data points clearly not correct, mostly due to multi-path reflections, were ignored and the next correct data point was used. A multi-path reflection simply means that the signal from the satellite reflected off of some object before being received by the GPS unit (Dean, D. pers. comm.). Statistical analysis was used to test that the laser distance was not different than the GPS distance.

Reach capacity is defined as the percentage of the tract covered by a zone of specified distance, measured perpendicular to the road and completely surrounding the road. Excess reach capacity is a measure of road efficiency and is the total area of all possible road overlaps expressed as a percentage of the reach capacity (Dean 2003). The WVDOF recommends a spacing of 200 feet between skid roads, therefore a 100 foot buffer was used around each skid road to determine reach capacity. All the buffers were then merged into one shapefile, and the individual borders of each buffer was dissolved to form one contiguous polygon. The area of this object was then calculated and the ratio was taken with respect to the total harvest size to determine reach capacity. Excess reach capacity was determined in much the same way. First, the intersect tool was used to find 
the area where skid road buffers overlapped. These were then merged and dissolved in the same manner as reach capacity. The ratio of the area of these areas to reach capacity was then taken to determine the percentage of the harvestable area that can be reached by more than one road, or the excess reach capacity.

Because reach and excess reach capacity are relatively new measures (Dean 2003), potential correlations exist among the variables of road density, reach capacity and excess reach capacity. Pearson's correlation coefficients were used to test for relationships between reach and excess reach capacity, road density and reach capacity, and road density and excess reach capacity.

Slopes of the sites were determined by using a 30-meter resolution digital elevation model (DEM). The DEM for the entire state of West Virginia was obtained from the Natural Resources Analysis Center at West Virginia University, which was then clipped down to the size of each individual site. The average of all 30-meter cells within each site was used to determine the average cross slope for each site. 


\section{Results}

A total of 18 sites were originally selected for use in this study. One large, company-owned FSP site, however, had extensive harvest activity adjacent to our selected harvest, which made it impossible to determine the harvest boundary. This site was subsequently dropped from the study, along with one non-FSP site. Another stewardship site was not completed due to time constraints. Hence, a total of 15 sites were used in this study (Figure 5). A total of 190 acres were sampled on non-FSP

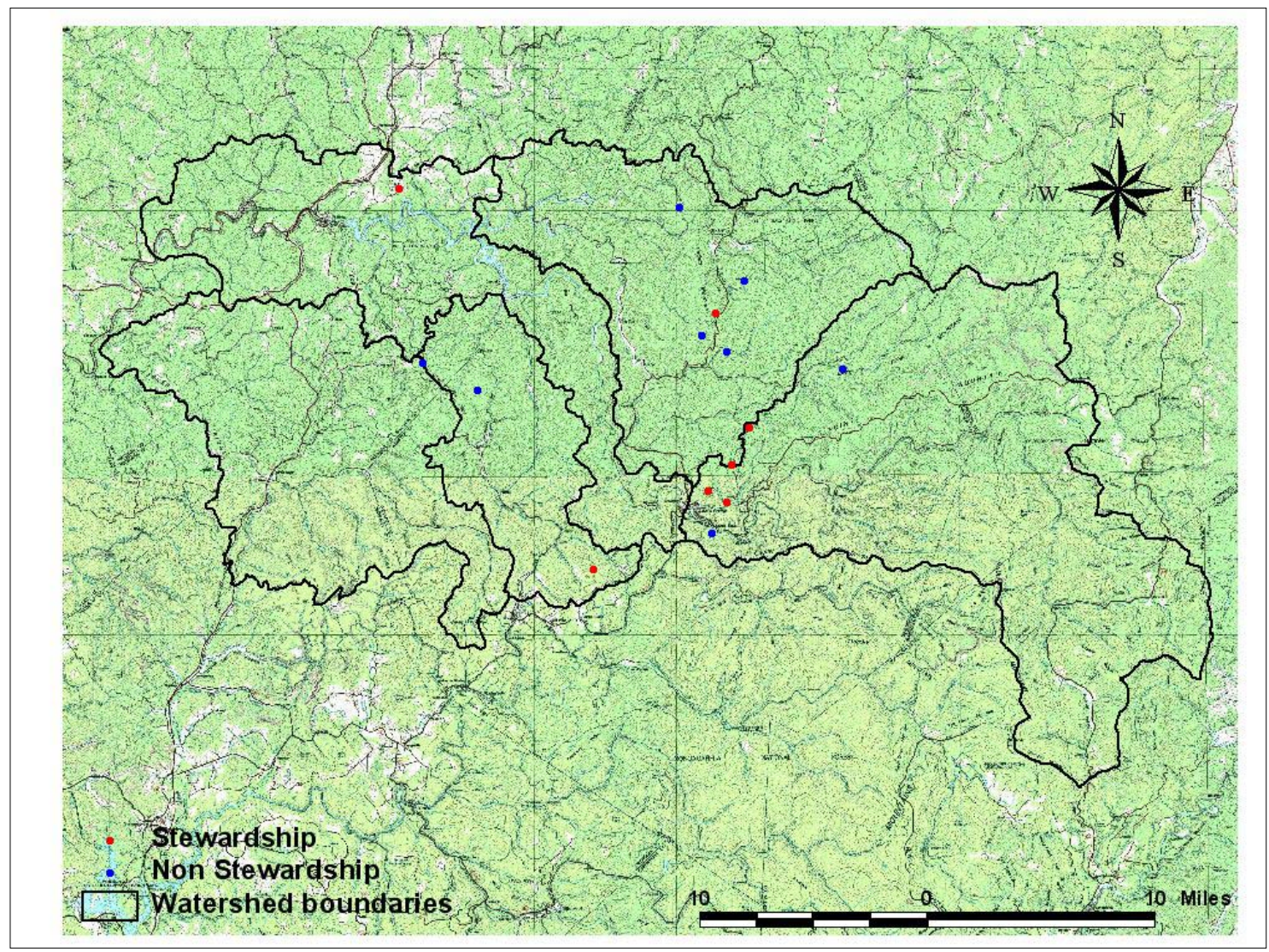

Figure 5. Map showing the location of the 15 study sites used in this study.

properties, and 280 acres were sampled on FSP properties, for a grand total of 470 total acres. Average size of the harvest was 25 acres for non-FSP and 40 acres for FSP. The average of 40 acres for FSP properties is affected heavily by the fact that one property 
was 146 acres in size. The median area of FSP properties is 16 acres and that of non-FSP properties is 25 acres. Average slopes of non-FSP sites ranged from $15 \%$ to $38 \%$, and had a mean of $25 \%$. Slopes on FSP properties ranged from $14 \%$ to $29 \%$, and had a mean of $22 \%$. There was no significant difference between these two property types with respect to cross slopes $(\mathrm{p}=0.35)$. Truck roads were not included in this study because on only four sites did a truck road occur that was used only for the harvest were were interested. More often, truck roads were county roads or roads otherwise open to the public.

\section{Residual Vegetation Plots}

Sixty-eight 0.10 -acre plots were measured on non-FSP properties, and 710.10 acre plots were measured on the FSP properties. Percentages of the total acreage sampled on each property type were 3.6 and 2.5 , respectively. On average, non-FSP properties were 50\% stocked, while FSP properties were 65\% stocked. Despite this $15 \%$ difference in stocking, statistical analysis shows no significant difference $(p=0.25)$. The quadratic mean diameter (QMD) for all trees measured on non-FSP properties was 8.4 inches, with an average basal area of $75 \mathrm{ft}^{2} \mathrm{ac}^{-1}$. In comparison, FSP properties had an average QMD for all trees of 9.5 inches and an average basal area of $98 \mathrm{ft}^{2} \mathrm{ac}^{-1}$ (Table 2). Analysis revealed that there are no significant differences in basal area $(p=0.24)$ or $\mathrm{QMD}_{\mathrm{t}}(\mathrm{p}=0.17)$ between the two property types. A close look at table 1 reveals that there is a high degree of variation within the variables tested, which may make it difficult to reject the null hypothesis. 
Table 2. Residual stand data by property type and site. Percent Oaks, CAPs and Maple are percentages of the total basal area.

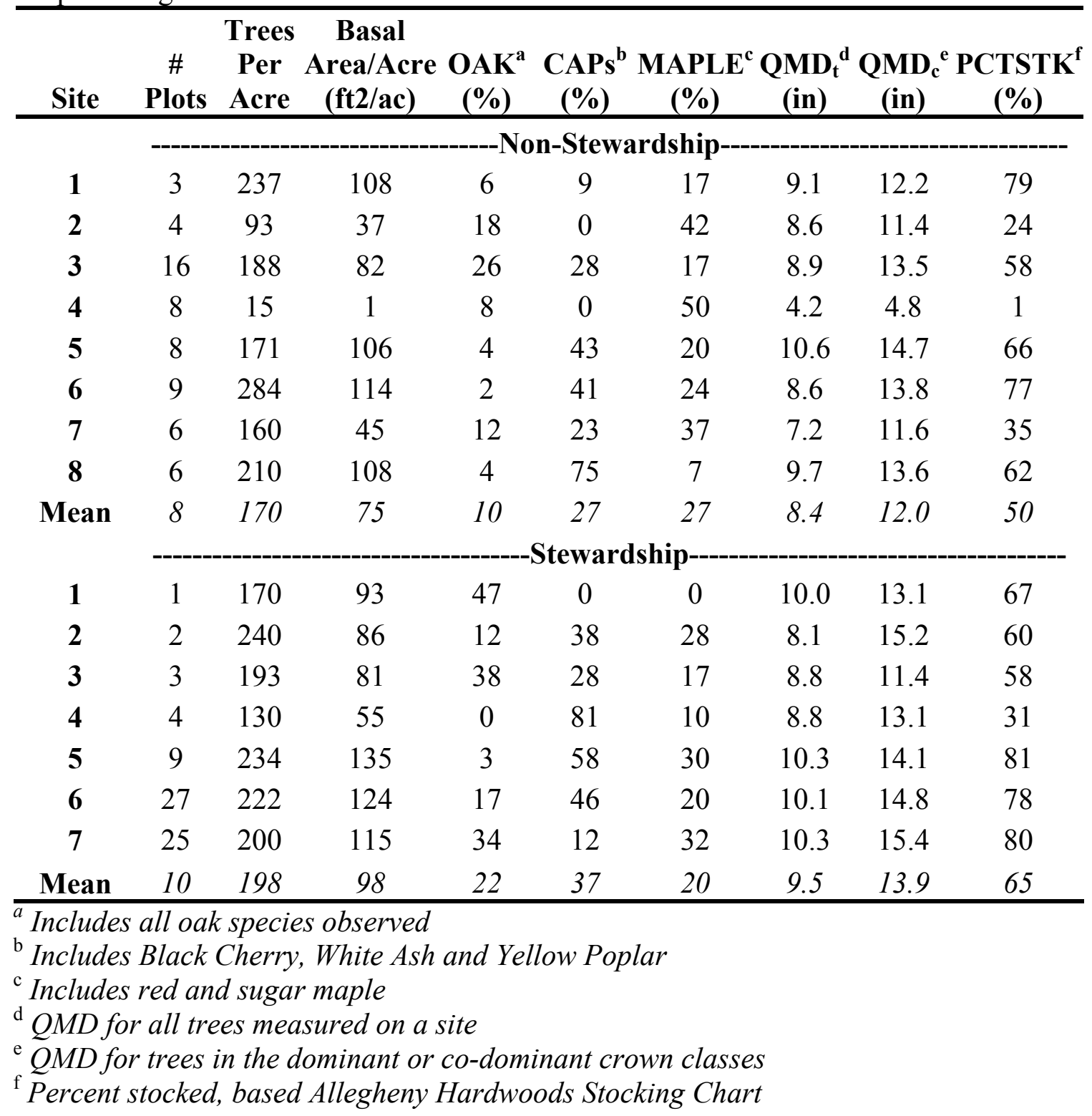

\section{Skid Road Attributes}

Both property types had the same average number of primary skid roads per site, with a mean of 10 . The number of roads on a site ranged from 5 to 17 on non-FSP properties, and from 4 to 20 on FSP properties. Road density was statistically higher for non-FSP properties than for FSP properties, with $247 \mathrm{ft} \mathrm{ac}^{-1}$ and $193 \mathrm{ft} \mathrm{ac}^{-1}$, respectively, $(p=0.04)$. Overall, five of the seven sites with the lowest road densities were FSP 
properties, while the four sites with the highest road densities were non-FSP properties (Figure 6.).

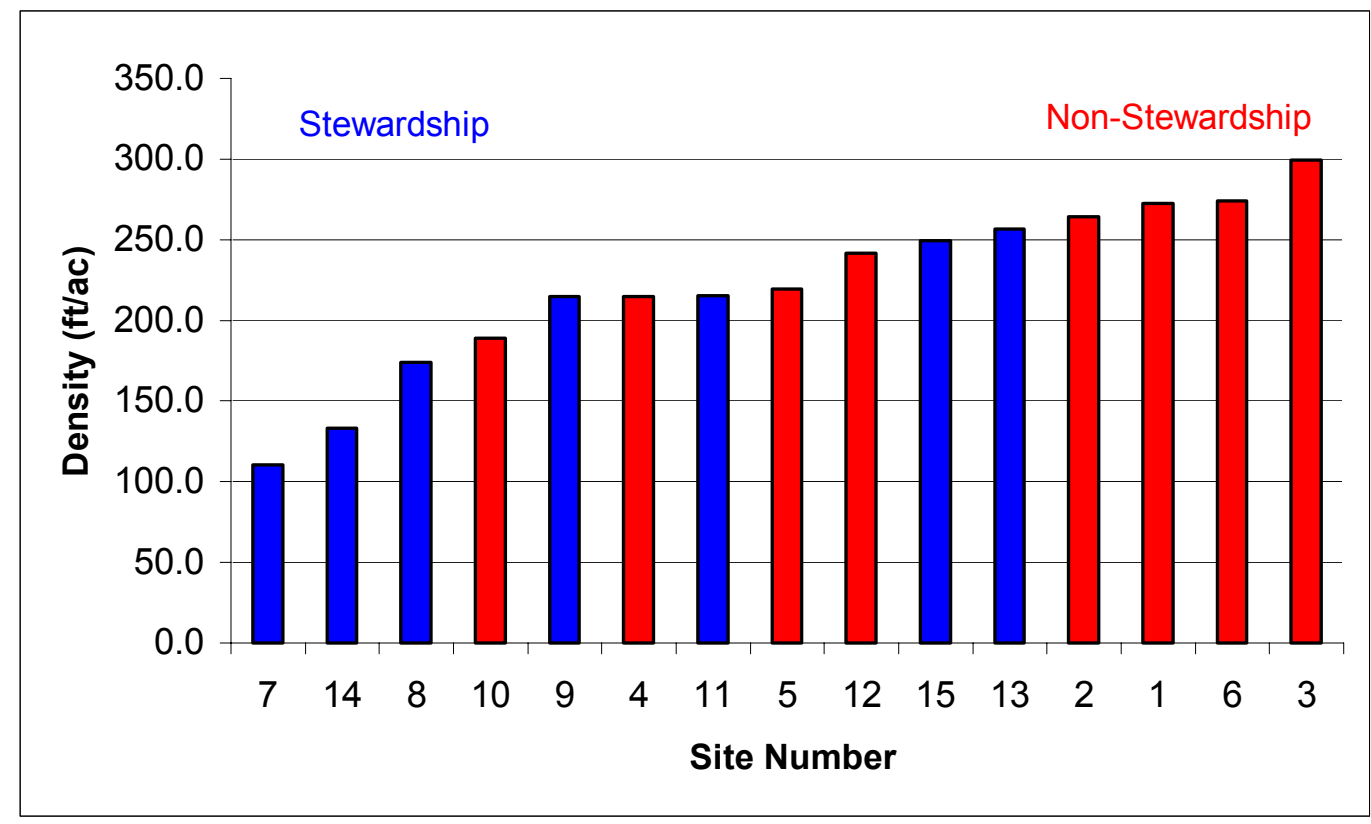

Figure 6. Road Density by site and property type. The sites are put in ascending order from lowest road density to highest.

Average road width was $10.1 \mathrm{ft}$ for non-FSP and $11.8 \mathrm{ft}$ for FSP $(\mathrm{p}=0.20)$, while average road length was $700 \mathrm{ft}$ for non-FSP and $567 \mathrm{ft}$ for FSP properties $(\mathrm{p}=0.38)$. The road distances measured by the laser and by the GPS unit were not statistically different $(p=0.15)$. Average road grade was slightly less for non-FSP properties $(12.9 \%)$ than for FSP properties $(13.5 \%)$, and was not statistically different $(p=0.76)$. Cut height averaged $4.1 \mathrm{ft}$ for non-FSP properties, compared with $3.5 \mathrm{ft}$ for FSP properties $(\mathrm{p}=$ 0.49 ). Reach capacity averaged $82 \%$ on non-FSP properties and $71 \%$ on FSP properties. Despite the $11 \%$ difference in the values, they were not significantly different $(p=.10)$. Excess reach capacity was identical on the two property types, averaging $41 \%$ on both property types $(\mathrm{p}=.91)$ (Tables 3,4$)$. Pearson correlation coefficients show no 
relationship between reach and excess reach capacity $(\mathrm{p}=0.42)$ or road density and excess reach capacity $(\mathrm{p}=0.17)$, but reach capacity does increase as road density increases $(\mathrm{p}=<0.0001)$ (figure 7$)$. For maps detailing skid road layout, reach capacity and excess reach capacity, see Appendices A, B and C, respectively.

\section{Grade Distributions}

Grade distributions are reported in road density (ft/ac) for each class (Appendix D). The WVDOF recommends that grades on skid roads not exceed $15 \%$, except for short sections. Thus, a favorable distribution is one in which much of the road density falls within the grade classes 1,2 or 3 . This distribution is skewed to the right and would have a positive skewness value (figures 8,9). Analysis of skewness values of each distribution show that there are no significant differences between the property types with regards to these grade distributions $(\mathrm{p}=0.66)$.

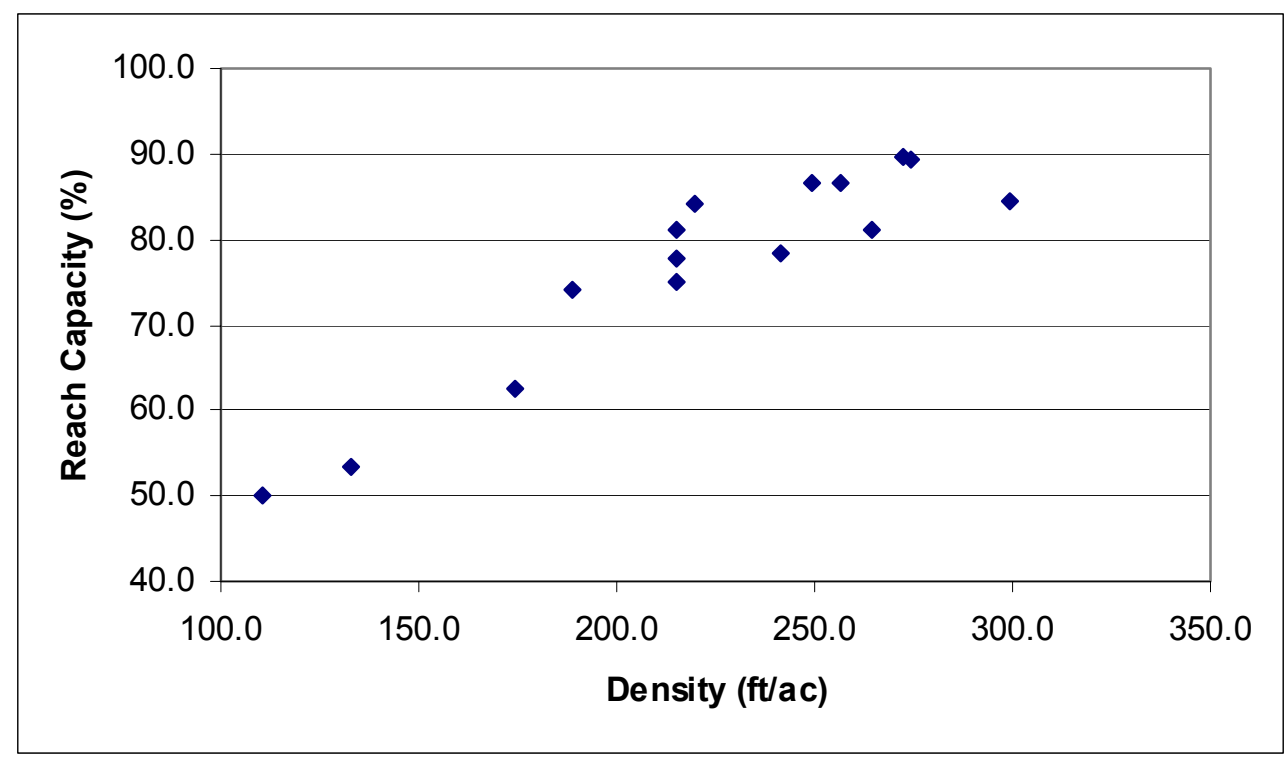

Figure 7. Relationship between road density and reach capacity. 


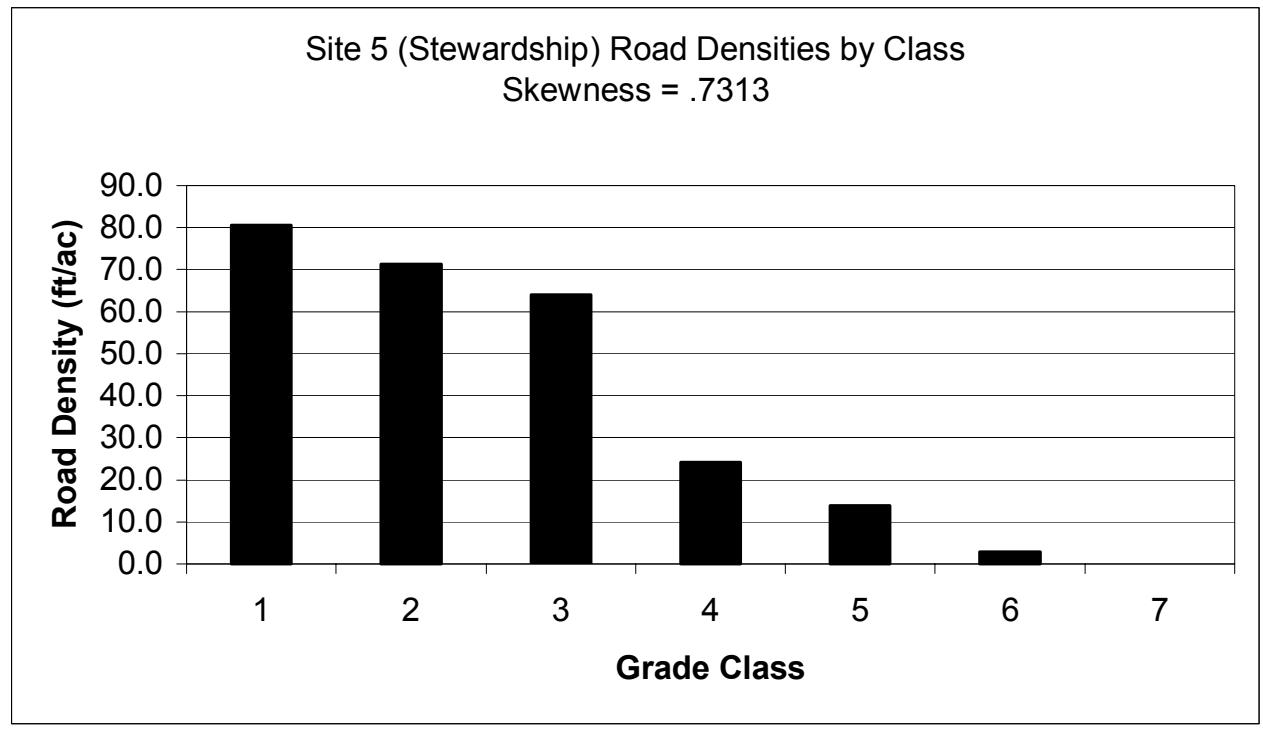

Figure 8. Right skewed grade distribution with a positive skewness value.

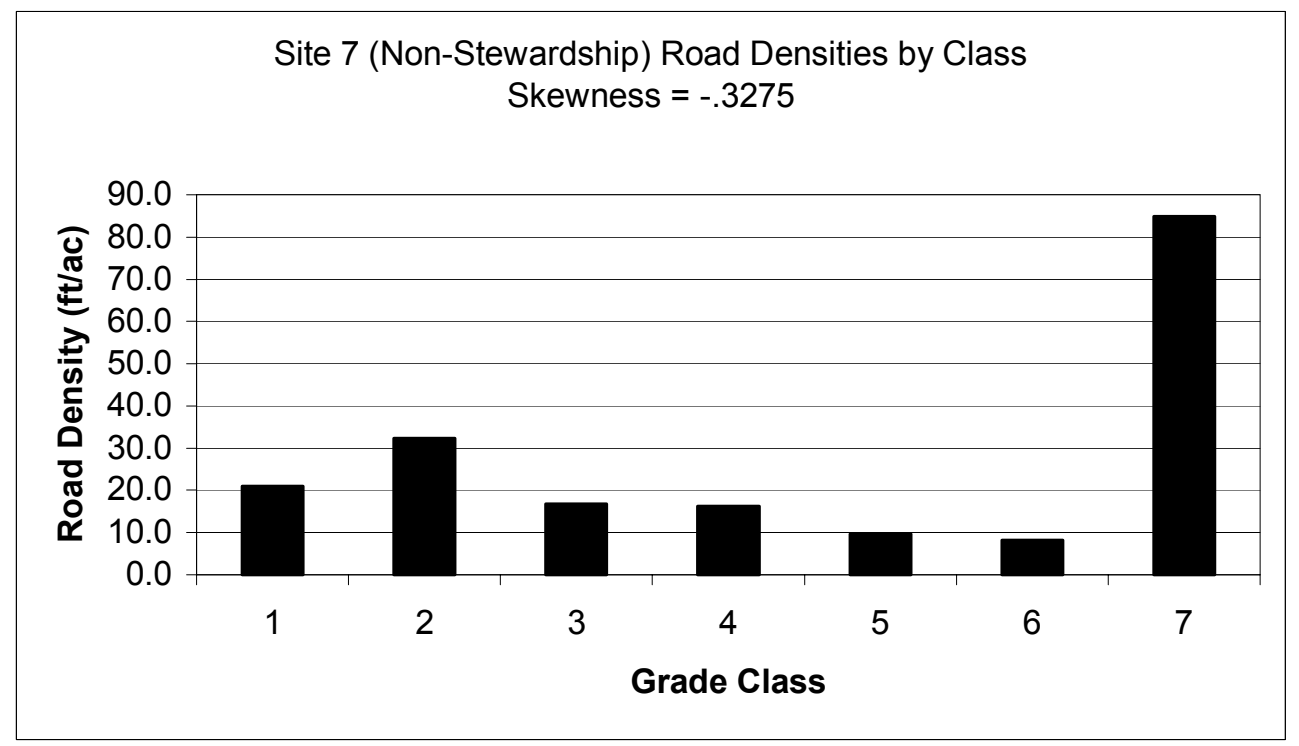

Figure 9. Left skewed grade distribution with a negative skewness value. 
Table 3. Primary calculated skid road attributes for property types by site.

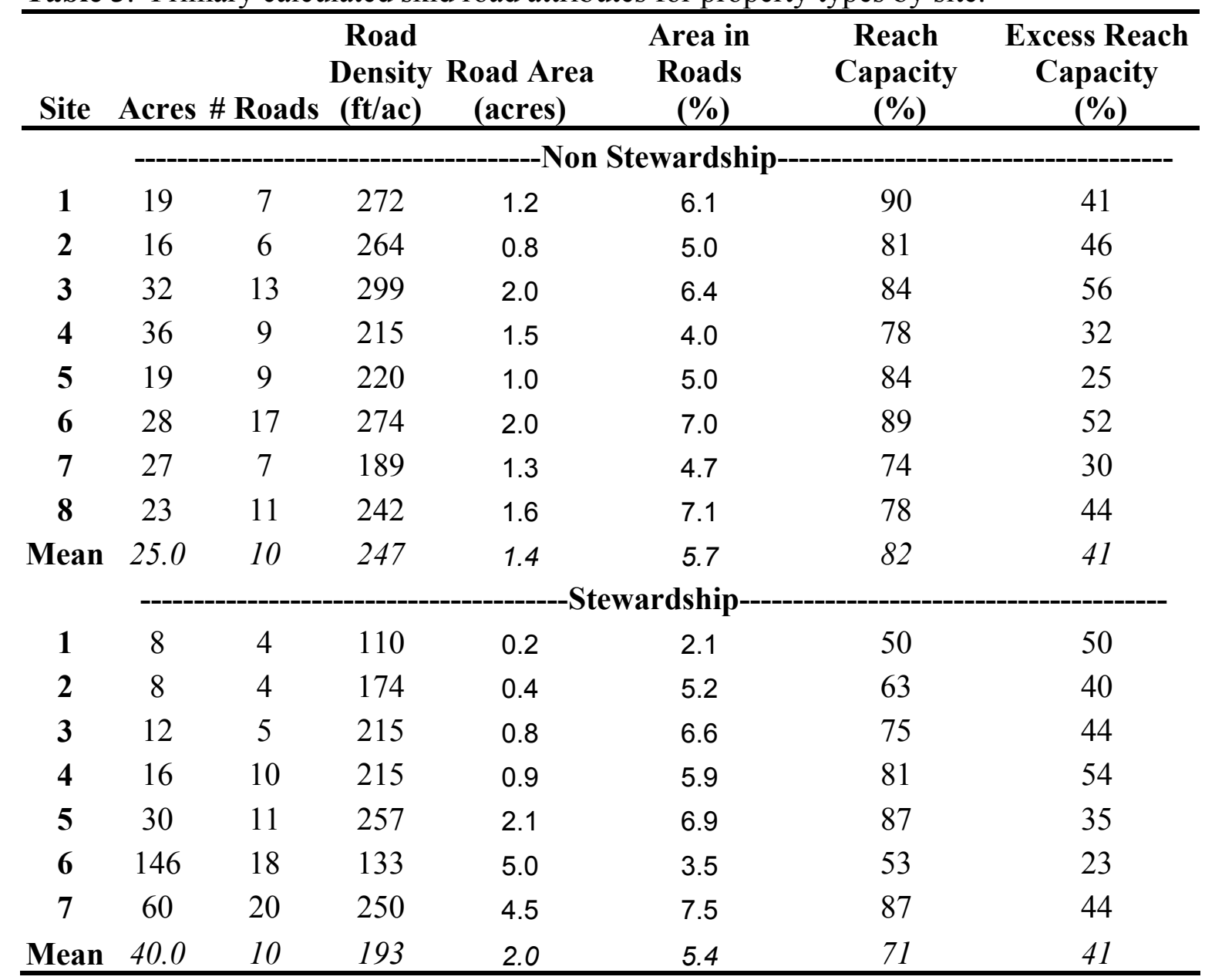


Table 4. Primary measured skid road attributes for property types by site.

\begin{tabular}{|c|c|c|c|c|c|}
\hline Site & Acres & $\begin{array}{c}\text { Width } \\
\text { (ft) }\end{array}$ & $\begin{array}{c}\text { Av. } \\
\text { Length } \\
\text { (ft) }\end{array}$ & $\begin{array}{c}\text { Road } \\
\text { Grade }(\%) \\
\end{array}$ & $\begin{array}{c}\text { Cut Height } \\
\text { (ft) }\end{array}$ \\
\hline & \multicolumn{5}{|c|}{-----------------Non-Stewardship----------------- } \\
\hline 1 & 19 & 9.8 & 739 & 11.8 & 2.7 \\
\hline 2 & 16 & 8.3 & 705 & 12.1 & 5.3 \\
\hline 3 & 32 & 9.3 & 736 & 14.1 & 4.7 \\
\hline 4 & 36 & 8.2 & 860 & 11.9 & 2.9 \\
\hline 5 & 19 & 10.0 & 834 & 10.7 & 4.1 \\
\hline 6 & 28 & 11.1 & 452 & 16.7 & 5.6 \\
\hline 7 & 27 & 10.9 & 728 & 17.7 & 4.4 \\
\hline 8 & 23 & 12.8 & 549 & 8.1 & 3.0 \\
\hline \multirow[t]{2}{*}{ Mean } & 25.0 & 10.1 & 700 & 12.9 & 4.1 \\
\hline & \multicolumn{5}{|c|}{--Stewardship----------------- } \\
\hline 1 & 8 & 8.3 & 221 & 18.7 & 0.5 \\
\hline 2 & 8 & 12.9 & 348 & 13.8 & 4.0 \\
\hline 3 & 12 & 13.3 & 516 & 8.9 & 2.2 \\
\hline 4 & 16 & 12.0 & 341 & 13.6 & 6.2 \\
\hline 5 & 30 & 11.7 & 700 & 10.3 & 2.9 \\
\hline 6 & 146 & 11.3 & 1079 & 13.3 & 4.3 \\
\hline 7 & 60 & 12.9 & 761 & 15.6 & 4.5 \\
\hline Mean & 40.0 & 11.8 & 567 & 13.5 & 3.5 \\
\hline
\end{tabular}




\section{Erosion and BMP Compliance}

Erosion had a mean value of 1.4 for non-FSP, and 1.3 for FSP properties; these were not statistically different $(p=0.64)$. There were very few instances of severe erosion observed on any of the 15 sites, despite the relatively steep terrain (Table 5). No instances of category 5 erosion were seen, and no landings had erosion worse than a category 2 (rill up to 6 inches), while a skid road was found that had category 3 erosion (rills 6-12 inches) on only $27 \%$ of the 15 total sites, and category 4 (rills $12-14$ inches) on only $13 \%$ of the sites. Brynn and Clausen (1991) found a similar trend on their sites in Vermont.

Table 5. Erosion categories and the percent of sites in which that category was found.

\begin{tabular}{ccc}
\hline & \multicolumn{2}{c}{ Percentage of Sites } \\
\cline { 2 - 3 } Erosion Category & Skid Roads & Landings \\
1. None to Slight & 100 & 83 \\
2. Rills up to 6" & 80 & 17 \\
3. Rills 6-12" & 27 & 0 \\
4. Rills 12-24" & 13 & 0 \\
5. Rills 24"+ & 0 & 0 \\
\hline
\end{tabular}

BMP compliance was calculated by pooling the two most common practices, broad based dips and waterbars, using the spacing standards for waterbars, as recommended by the WVDOF. Mean BMP compliance was $58 \%$ on non-FSP sites, and $34 \%$ on FSP properties, and was significantly different $(F=21.38, p=0.0005)$. BMP compliance was slightly lower on grades $15 \%$ or greater for non-FSP properties $(51 \%)$, and for FSP properties (26\%). Ninety-six percent of the waterbars observed on non-FSP properties were functional, while $83 \%$ of the waterbars on FSP properties were functional $(\mathrm{p}=0.17)$. The lower functional percentage on FSP properties is probably affected by 
one FSP property that had a functional rate of only $33 \%$. Ninety-two percent of the waterbars were up to WVDOF specifications on non-FSP properties, while $93 \%$ were up to specification on FSP properties $(\mathrm{p}=0.36)$. One hundred percent of the broad based dips observed were functional, while only $50 \%$ of the dips observed were up to WVDOF specifications. Interestingly, $81 \%$ of the broad-based dips observed were seen on FSP properties. However, two FSP sites accounted for $46 \%$ of these broad-based dips. Waterbars accounted for almost $94 \%$ of the total BMP structures encountered.

BMP compliance rates varied by grade class. Statistical differences were found on the lower three grade classes, but not on the higher three grade classes (Table 6, Figure 10). Non-FSP properties had a declining trend where compliance was relatively high in the lower grade classes, and lower in higher grade classes. On FSP properties, there was a declining trend seen until category 3 , then there is an increase until category five. A slight decrease is seen from category five to category 6 . Vegetation percentage on road segments $15 \%$ or greater had a mean value of $65 \%$ on non-FSP properties and $76 \%$ on FSP properties $(\mathrm{p}=0.46)$. Low levels of rutting were seen on the study sites, with both property types having a mean value of $1.1(p=0.89)$ (Table 7). Level of BMP compliance (fully, partially, or noncompliant) did not affect the amount of erosion seen $(p=0.28)$, however, erosion did increase as grade increased $(p=0.0004)$. Erosion was similar on road segments for which compliance could be determined, and segments which were too short to determine compliance $(p=0.36)$. 
Table 6. BMP significance values by grade class.

\section{Grade Class}

1

2

3

4

5

6
Included Grades

$0-9.9 \%$

$10-14.9 \%$

$15-19.9 \%$

$20-24.9 \%$

$24-29.9 \%$

$30 \%+$
Significance

0.0337

0.0054

0.0012

0.4106

0.306

0.9895

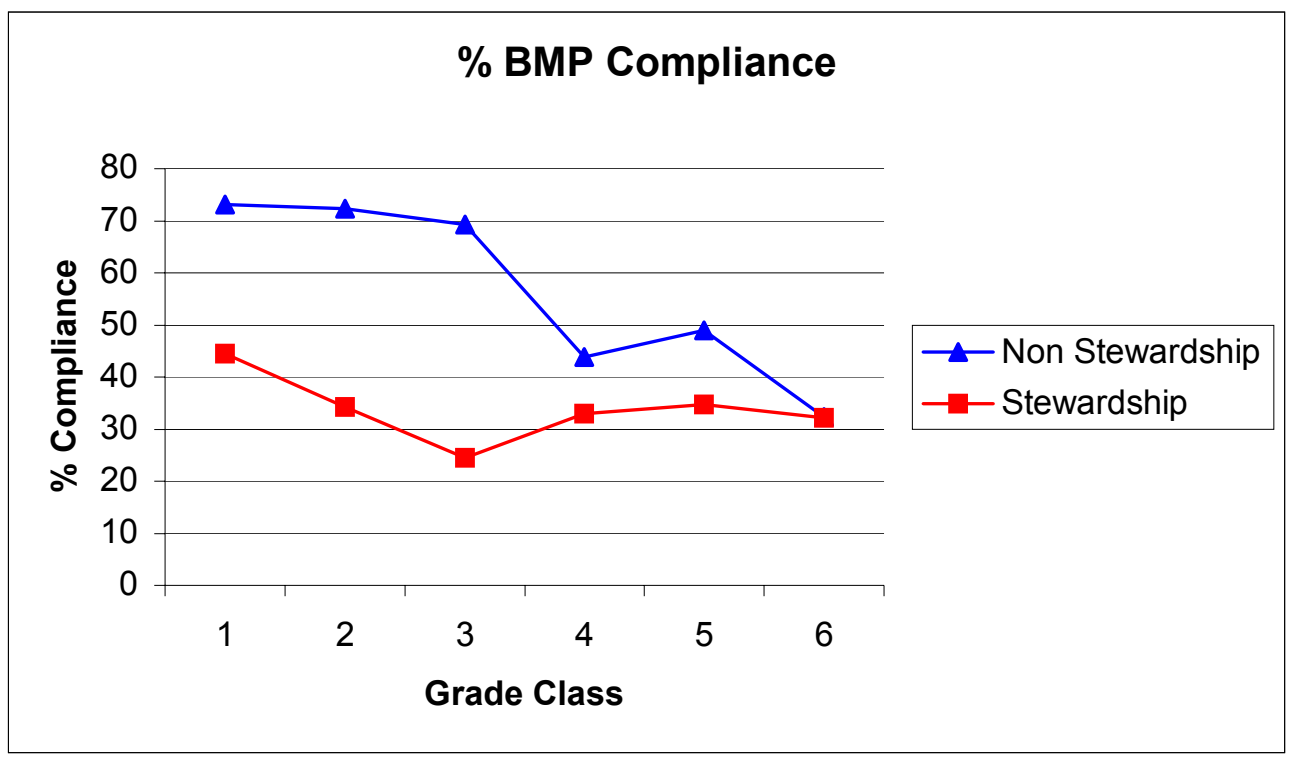

Figure 10. BMP compliance trends for the property types. 
Table 7. Erosion and BMP compliance measures by property type and site. Erosion and rutting are a categorical value that ranges from 1 (lowest) to 5 (highest). WB Compliance $15 \%$ corresponds to the BMP compliance percentage on road segments with a grade greater than or equal to $15 \%$. Vegetation percent is the percent of the road segment ocularly estimated to be vegetated. This is only for road segments $15 \%$ or greater.

\begin{tabular}{|c|c|c|c|c|c|c|c|c|}
\hline \multirow[t]{2}{*}{ Site } & Acres & Erosion & Rutting & $\begin{array}{r}\text { BMP } \\
\text { Complia } \\
(\%) \\
\end{array}$ & $\begin{array}{l}\text { BMP } \\
\text { mpliance } \\
15 \%\end{array}$ & \multicolumn{2}{|c|}{$\begin{array}{cc}\% & \% \text { Up } \\
\text { Functional to Spec } \\
\end{array}$} & $\begin{array}{c}\text { Vegetation } \\
(\%) \\
\end{array}$ \\
\hline & & & & --Nor & ardship-- & . & & -----" \\
\hline 1 & 19 & 1.2 & 1.0 & 47 & 51 & 97 & 100 & 75 \\
\hline 2 & 16 & 1.1 & 1.0 & 77 & 72 & 95 & 82 & 65 \\
\hline 3 & 32 & 1.1 & 1.1 & 59 & 52 & 97 & 92 & 81 \\
\hline 4 & 36 & 1.5 & 1.0 & 40 & 41 & 100 & 97 & 51 \\
\hline 5 & 19 & 1.1 & 1.0 & 55 & 40 & 98 & 93 & 95 \\
\hline 6 & 28 & 1.8 & 1.1 & 66 & 51 & 94 & 88 & 33 \\
\hline 7 & 27 & 2.0 & 1.1 & 65 & 59 & 91 & 93 & 77 \\
\hline 8 & 23 & 1.3 & 1.1 & 59 & 38 & 94 & 89 & 40 \\
\hline Mean & 25.0 & 1.4 & 1.1 & 58 & 51 & 96 & 92 & 65 \\
\hline 1 & 8 & 1.0 & 1.0 & 40 & $\begin{array}{c}\text { dship-- } \\
60\end{array}$ & 78 & 100 & 100 \\
\hline 2 & 8 & 1.5 & 1.0 & 21 & 11 & 100 & 100 & 58 \\
\hline 3 & 12 & 1.0 & 1.0 & 26 & 0 & 33 & 67 & 100 \\
\hline 4 & 16 & 2.0 & 1.4 & 28 & 27 & 82 & 94 & 41 \\
\hline 5 & 30 & 1.0 & 1.1 & 38 & 13 & 89 & 94 & 94 \\
\hline 6 & 146 & 1.2 & 1.1 & 42 & 37 & 99 & 96 & 67 \\
\hline 7 & 60 & 1.1 & 1.0 & 42 & 38 & 97 & 97 & 73 \\
\hline Mean & 40.0 & 1.3 & 1.1 & 34 & 26 & 83 & 93 & 76 \\
\hline
\end{tabular}

\section{Log Landings}

Twelve log landings were measured during this study. One log landing could not be definitively located because it was in a farm field, and 2 log landings had been converted to other uses, and shapes and boundaries had been altered. A house was built on the landing in one site, and an access road had been built in the landing of another site. Landings measured on this study were generally small, with the average landing size being only 0.17 acres in size on both property types $(p=0.95)$. Landing size ranged from 
0.08 acres on a non-FSP property to 0.31 acres on a FSP property. All landings had some grade associated with them, as high as $16 \%$ on a FSP property, to as low as $0.5 \%$ on a non-FSP property. Mean values were $5.3 \%$ on non-FSP properties and $8.4 \%$ on FSP properties $(\mathrm{p}=0.34)$. All landings were vegetated with non-FSP properties having a mean value of $94 \%$ vegetated, and FSP properties having a mean value of $83 \%(\mathrm{p}=$ 0.56). Very little occurrences of erosion were seen in these landings, with only two sites, both on non-FSP properties, having erosion values greater than a category one. All landings on FSP sites had no more than category 1 erosion present and an overall mean of 1, while two non-FSP sites had category 2 erosion present. Non-FSP properties had an overall mean of 1.3 (Table 8). There was no significant difference with respect to erosion $(\mathrm{P}=.17)$ 
Table 8. Log landing data separated by site and property type. Erosion values are categorical, ranging from 1 (lowest) to 5 (highest). Only one landing was observed on each site.

\begin{tabular}{|c|c|c|c|c|c|c|c|c|c|}
\hline \multirow[b]{2}{*}{ Site } & \multirow[b]{2}{*}{$\begin{array}{c}\text { Length } \\
\text { (ft) }\end{array}$} & \multirow[b]{2}{*}{$\begin{array}{c}\text { Width } \\
\text { (ft) }\end{array}$} & \multirow[b]{2}{*}{$\begin{array}{c}\text { Area } \\
\text { (acres) }\end{array}$} & \multirow[b]{2}{*}{$\begin{array}{c}\text { Grade } \\
(\%) \\
\end{array}$} & \multirow[b]{2}{*}{$\begin{array}{c}\text { Vegetation } \\
(\%)\end{array}$} & \multirow[b]{2}{*}{ Erosion } & \multicolumn{3}{|c|}{---Largest Slash Pile--- } \\
\hline & & & & & & & $\begin{array}{l}\text { Length } \\
\text { (ft) }\end{array}$ & $\begin{array}{c}\text { Width } \\
\text { (ft) }\end{array}$ & $\begin{array}{c}\text { Height } \\
\text { (ft) }\end{array}$ \\
\hline & & & & $----N$ & on Stewards & hip----- & 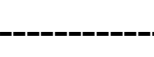 & 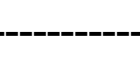 & ------- \\
\hline 1 & 113 & 32 & 0.08 & 3.1 & 100 & 1 & 80 & 20 & 8 \\
\hline 2 & 93 & 135 & 0.29 & 4 & 100 & 1 & 3 & 60 & 6 \\
\hline 3 & 78 & 58 & 0.10 & 2.6 & 100 & 1 & 29 & 13 & 6 \\
\hline 4 & 108 & 77 & 0.19 & 14.5 & 100 & 1 & 75 & 45 & 10 \\
\hline 6 & 114 & 84 & 0.22 & 11 & 100 & 1 & 30 & 10 & 4 \\
\hline 7 & 205 & 28 & 0.13 & 0.5 & 100 & 2 & 55 & 6 & 3 \\
\hline 8 & 112 & 62 & 0.16 & 1.5 & 60 & 2 & 79 & 17 & 6 \\
\hline Mean & 117.6 & 68.0 & 0.17 & 5.3 & 94 & 1.3 & 50.1 & 24.4 & 6.1 \\
\hline 3 & 118 & 32 & 0.09 & 16 & $\begin{array}{c}\text { Stewardship } \\
100\end{array}$ & 1 & 0 & 0 & 0 \\
\hline 4 & 106 & 65 & 0.16 & 6 & 15 & 1 & 86 & 21 & 5.5 \\
\hline 5 & 97 & 50 & 0.11 & 10.3 & 100 & 1 & 0 & 0 & 0 \\
\hline 6 & 107 & 67 & 0.16 & 3 & 100 & 1 & 97 & 28 & 7 \\
\hline 7 & 132 & 101 & 0.31 & 6.6 & 100 & 1 & 55 & 11 & 8 \\
\hline Mean & 112.0 & 63.0 & 0.17 & 8.4 & 83 & 1.0 & 47.6 & 12.0 & 4.1 \\
\hline
\end{tabular}

\section{Landowner Objectives and Forester Involvement}

Landowner objectives varied greatly from landowner to landowner (table 9).

Timber companies who owned land expressed desire to generate revenue from harvesting while doing so in a sustainable, long term manner. Two NIPF landowners also expressed a desire to generate revenue from harvesting. A timber stand improvement (TSI) was the main objective on two properties, although a commercial harvest did occur on both. Harvesting of mature timber, and forest health were also objectives. 
Forester involvement was more variable on FSP properties, and seemed to be higher on non-FSP properties. This result is probably because of company lands, which all reported a high level of forester involvement in their timber sales.

Table 9. Level of forester involvement on the timber sales involved in this study.

\begin{tabular}{|c|c|c|c|}
\hline Site & Company land & $\begin{array}{c}\text { Level of Forester } \\
\text { Involvement }\end{array}$ & Objective(s) \\
\hline & \multicolumn{3}{|c|}{----------------Non-Stewardship----------------- } \\
\hline 1 & Y & $\mathrm{HIGH}$ & Income \\
\hline 2 & $\mathrm{~N}$ & $\mathrm{HIGH}$ & Income \\
\hline 3 & Y & $\mathrm{HIGH}$ & Income \\
\hline 4 & Y & $\mathrm{HIGH}$ & Income \\
\hline 5 & $\mathrm{~N}$ & NOT CONTACTED & NA \\
\hline 6 & Y & $\mathrm{HIGH}$ & Income \\
\hline 7 & $\mathrm{~N}$ & NONE & Timber Mature \\
\hline \multirow[t]{2}{*}{8} & $\mathrm{~N}$ & LOW & Income \\
\hline & & ----Stewardship----- & TSI \\
\hline 1 & $\mathrm{~N}$ & NOT CONTACTED & TSI \\
\hline 2 & $\mathrm{~N}$ & NONE & Several \\
\hline 3 & $\mathrm{~N}$ & $\mathrm{HIGH}$ & Forest Health \\
\hline 4 & $\mathrm{~N}$ & NONE & Income \\
\hline 5 & $\mathrm{~N}$ & LOW & TSI \\
\hline 6 & $\mathrm{~N}$ & MEDIUM & Timber Mature \\
\hline 7 & Y & $\mathrm{HIGH}$ & Income \\
\hline
\end{tabular}




\section{Discussion}

Minimizing the impact of harvest road systems is a primary goal in sustainable forest management, and maximizing efficiency of these systems is central to logging operations. Three road attributes (percent of harvest in roads and landings, road width and road density) in this study have lower values than those shown by Kochenderfer (1977) (Table 10). The values reported for Kochenderfer are for skidder logged areas in West Virginia. Conversations with state service foresters in the watersheds where this study took place suggest that the lower value may be the result of a difference in logging systems. Logging in the watersheds solely with skidders is rare, and that transport of wood to the landing is probably by dozer rather than skidders. Even on larger sites, dozers may work smaller roads secondary to one large, main skid trail on which a skidder may operate. Dozers are able to operate on narrower road widths than a skidder, which will not only affect road widths in this study, but also the area in roads and landings.

Table 10. Road attributes of this study compared to Kochenderfer (1977).

\begin{tabular}{lcc}
\hline \multicolumn{1}{c}{ Variable } & This Study & Kochenderfer (1977) \\
\hline \% of Harvest in Roads and & & \\
Landings & 6.1 & 10.3 \\
Road Width & 10.9 & 16 \\
Density & 222 & 267 \\
\hline
\end{tabular}

A direct comparison between road densities is difficult due to the difference in how secondary roads were treated in these studies. Kochenderfer (1977) sampled severely damaged secondary skid roads, while all secondary roads in this study were ignored. It is not likely, however, that this alone accounts for the lower road density seen here. The slope of the areas are different as well, with Kochenderfer reporting steeper 
slopes (average slopes as high as $51 \%$ ), while the steepest slope in this study was $38 \%$.

Steeper slopes could require the building of more roads to access timber. The

Kochenderfer study was also completed 15 years before the passage of the LSCA in West Virginia. The impact the LSCA has on road density is not known, although it could be that this law has made loggers more aware of road planning and they are, therefore, building less roads than in the past.

From a close look at the data presented, it appears as though company or forest industry land may affect road density. Road densities between company land (262 ft/ac) and NIPF land $(211 \mathrm{ft} / \mathrm{ac})$ were statistically different $(\mathrm{p}=0.03)$, suggesting that higher road densities may be present on company land. Four out of five company harvests were on non-FSP properties. The difference in road density between FSP and non-FSP properties may be more of an effect from company versus NIPF lands, than from FSP versus non-FSP properties.

The average pooled waterbar compliance rate for this study was $43 \%$, compared with 48\% found by Whipkey (1991) and 58\% found by Egan et al (1998). When the waterbar compliance rate only on non-FSP properties (57\%) is used, the comparison is much more favorable. None of these previous studies included broad-based dips in their analysis, however broad-based dips were observed in fair numbers on FSP properties. Culverts, turn outs, and inside ditches were also observed on FSP properties, while none were observed on non-FSP properties. Importantly the lack of waterbars does not mean that BMPs are not being used on FSP properties, but may mean that alternative practices are being used instead of waterbars. Erosion was not affected in this study by BMP compliance. Segments with high BMP compliance did not show significantly less 
erosion than segments with low compliance. Further analysis of this data shows that segments not in compliance were shorter and less steep than segments that were fully or partially compliant. Therefore, it is less likely that erosion will be seen on these segments.

The use of these other BMPs by FSP ownerships may reflect landowner desire to better access their property. Anecdotal evidence from conversations with NIPF landowners suggests that FSP NIPF landowners want access to their land to gather firewood and for recreational purposes such as off-road vehicle use or for hiking. Of the six NIPF FSP properties, four lived on their property, one lived only a few miles away, and all lived in West Virginia. No non-FSP NIPF owner lived on their property, and three out of four of these landowners lived out-of-state. The proximity of FSP landowners to their land may influence the practices used on their property. One FSP landowner stated that he instructed the logger to place as few waterbars as possible so he was better able to access his property. Another used extensive broad-based dips so he was able to drive his pickup truck on the roads to haul firewood.

Erosion trends on this study were similar to a study completed by Brynn and Clausen (1991) in Vermont. A large percentage of sites had erosion in the lower classes, while a lower percentage of sites had erosion in the higher classes (table 11). In this study, a larger percentage of sites had erosion in the higher classes than did Brynn and Clausen. The steepness of the terrain that this study took place in could account for those differences. This study, similar to Brynn and Clausen, found no erosion in the highest erosion category. Only one site was less than two years old, and it has been reported that accelerated erosion usually ceases two years after road use ends (Reinhart et al. 1963); 
however, questions still remain over whether road use on many of these sites, especially the FSP sites, has actually ended. Many of the roads had much of their surface covered by vegetation, which may have hidden the presence of erosion.

Precipitation will also influence the amount of erosion observed. The years 2000 and 2001 were wet years compared to other years from which the harvests were drawn. 2003, the year in which measurements were taken, was the wettest of all the years included in this study. 1999 was the driest of all years included in this study, with less than 9 inches of rainfall recorded (Figure 11). The high rainfall amount in 2003 may have increased the erosion observed on these sites, especially the more recent harvests which have had less time to allow vegetation to take on skidroads.

Table 11. Percent of sites in which an erosion category occurred.

\begin{tabular}{|c|c|c|c|c|}
\hline \multirow[b]{2}{*}{ Erosion Category } & \multicolumn{4}{|c|}{ Percentage of Sites } \\
\hline & $\begin{array}{c}\text { Skid Roads } \\
\text { (This } \\
\text { Study) }\end{array}$ & $\begin{array}{c}\text { Skid Roads } \\
\text { (Brynn and } \\
\text { Clausen 1991) }\end{array}$ & $\begin{array}{c}\text { Landings } \\
\text { (This } \\
\text { Study) }\end{array}$ & $\begin{array}{c}\text { Landings } \\
\text { (Brynn and } \\
\text { Clausen 1991) }\end{array}$ \\
\hline None to Slight & 100 & 91 & 83 & 96 \\
\hline Rill up to 6" & 80 & 33 & 17 & 11 \\
\hline Rills 6-12" & 27 & 3 & 0 & 1 \\
\hline Rills 12-24" & 13 & 2 & 0 & 0 \\
\hline Rills 24"+ & 0 & 0 & 0 & 0 \\
\hline
\end{tabular}




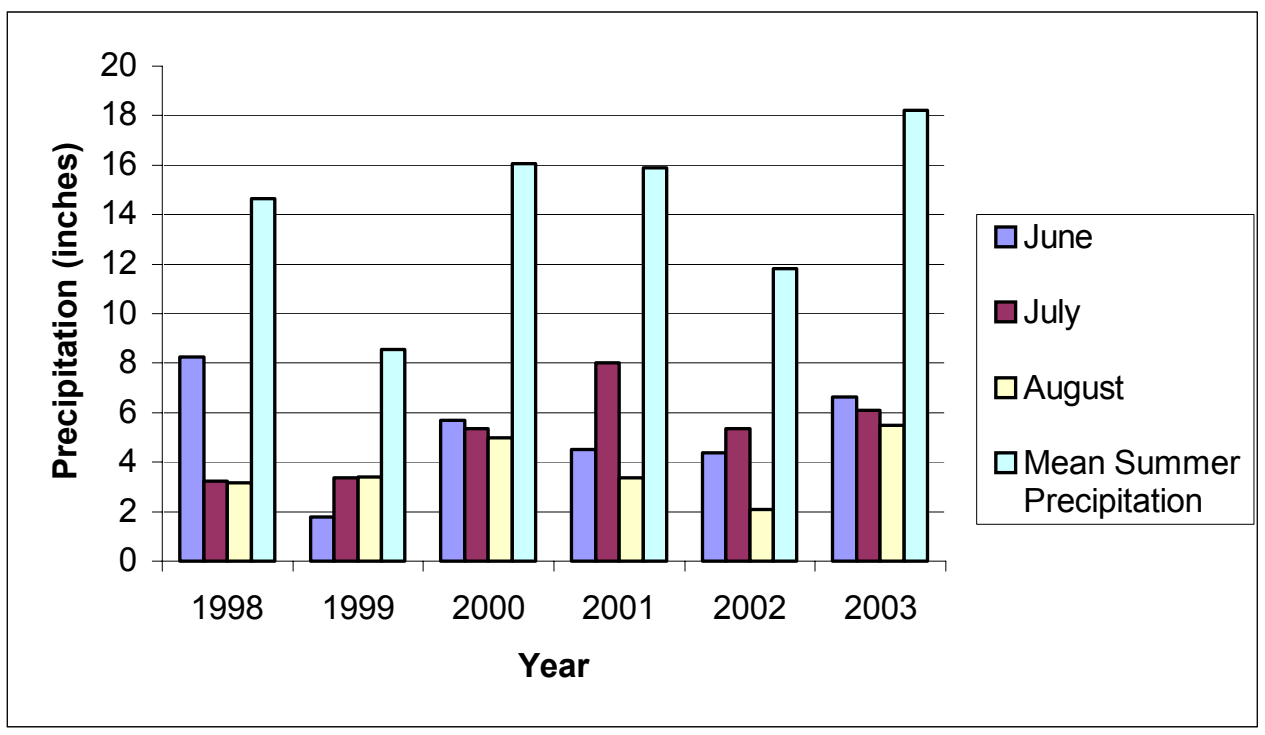

Figure 11. 1998-2003 summer precipitation data for West Virginia.

\section{Reach and Excess Reach Capacity}

The results of this study show that road densities may be lower now than in the past. Roads have been shown as a primary source of sedimentation to streams, and proper planning has been shown to reduce the road density on logging jobs. Road density is only one measure of the efficiency of road networks, and other metrics might be useful to aid natural resource professionals in planning new road networks, or comparing existing road networks. Reach and excess reach capacity are two relatively new metrics first proposed by Dean (2003) that may help to achieve this goal. Although the amount of information required to use these metrics in the planning stage is currently lacking in digital map form, they nonetheless can be used as a tool from which to learn and improve upon in future road systems (Dean 2003). When the information does become available, these metrics could be considered along with Egan's (1999) concepts of momentum, avoidance, and the universal soil loss equation to create permanent forest road systems 
that reduce erosion and sedimentation impacts to streams, as well as achieve maximum efficiency.

It is important to note that reach capacity may actually be higher on many sites than is reported in this study, due to the fact that secondary roads that access timber were not included in this study. It is probable that there may be no "good" reach capacity. That is, there may be no one standard of reach capacity that we can say is the optimum level to have on any particular harvest. This is because different landowners will have different objectives, and these objectives will influence the amount of timber a landowner wishes to reach. While forest industry may have a desire to achieve as close to $100 \%$ of the timber on a site as possible, a small NIPF landowner may only wish to access certain parts of their land, while leaving other areas roadless. This does not mean that reach capacity is not sufficient on this property, where reach capacity may be only $50 \%$ or less; this amount is probably fine for the landowner and, if the objectives of the harvest were met, the reach capacity could also be satisfactory, if all the timber the landowner wanted to harvest was, in fact, reachable. In short, when assessing reach capacity, the objectives of the particular harvest must be considered when deciding if the reach capacity is sufficient.

Excess reach capacity is different from reach capacity in that, regardless of the landowner objectives, there is probably some maximum level of excess reach that should not be exceeded. In this study, the average excess reach capacity for all sites combined was $41 \%$. This means that $41 \%$ of the harvestable area (or $41 \%$ of the reach capacity) can be reached by more than one skid road. It would seem that excess reach capacity can be separated into two categories "unavoidable" and "avoidable". "Unavoidable" excess 
reach capacity would be those areas of excess reach capacity that are inescapable, such as at road intersections. "Avoidable" excess reach capacity would be those areas of excess reach capacity that are preventable, such as when roads are closer than the 200 feet spacing recommended by the WVDOF. More research will be needed to find a "maximum excess reach capacity", although the excess reach capacity of $41 \%$ seems high.

The relationship of increasing reach capacity with increasing road density (figure 10) is expected, however better planning should make it possible to have relatively low road densities, yet have high reach capacities. Dean (2003) suggests that a road density of less than $210 \mathrm{ft} / \mathrm{ac}$ is reasonable for many logging jobs. It should be possible to achieve a "good" reach capacity while keeping road density under this threshold.

\section{Management Implications}

It is evident through previous research as well as this study that company or forest industry lands differ in some ways from general NIPF lands. Because of the large percentage of company lands in the study area, they were included. In future studies, choosing a study area in which these lands could be excluded might be helpful, or design a study that accounts for the effect of ownership type (industrial versus non-industrial) and property type (FSP versus non-FSP). This study reveals that differences do exist between FSP and non-FSP properties with respect to road densities and BMP implementation, although density is probably the result of a company or industry effect. BMP implementation rates may differ because of the FSP landowner's desire to access their property, which may often lead to fewer BMP structures implemented. The data 
also suggests that FSP landowners have a wider range of objectives than their non-FSP counterparts.

Although only $30 \%$ of the watersheds are owned by timber companies or forest industry, they account for four-fifths of the acreage harvested in the watersheds, during the five year period of interest. Because so much harvesting is taking place in these properties, they have the potential to be a detriment to the waterbodies within the watershed. They also have the opportunity to contribute to the overall health of the watersheds, through proper road planning and use of BMPs. Road density was high on these lands, and better planning of roads to lower road density, as well as increasing BMP compliance rates can help to minimize the impact that these lands have on waterbodies.

Although this study was not designed specifically to answer questions about forester involvement, it does suggest that there is less forester involvement on FSP properties than on non-FSP properties. One of the benefits of the FSP is that it gives access to natural resource professionals to landowners who may not otherwise have that access. A problem arises in that after the management plan is written, FSP landowners may not use these professionals in future management activities. A follow up system would be very helpful to FSP landowner who would like to implement their recommended practices, but may not know how to do so. This concept is not new, and has been recommended most recently by Jennings (2003). He suggests that this follow up system may be beneficial to both landowners, who will be more motivated to implement recommended practices, and foresters, who stand to gain financially from the implementation of recommendations. The FSP has the ability to contribute significantly 
to the overall health of a forested watershed. Follow-up by foresters, and ensuring loggers follow planned road layouts can further strengthen the program.

The concepts of reach capacity and excess reach capacity should be explored and researched further. In this study, they were two variables of many that were measured, and were not given the attention needed to develop standards. These metrics, at least in the short term, can be very useful as learning tools in which to gauge the efficiency of existing road systems. Future road systems can thus be improved. In the future, when the information required for proper planning is available digitally, the metrics will be excellent planning tools. Roads are the primary source of sedimentation, and proper planning of road systems can greatly reduce the amount of land in roads. Development of these metrics can help meet the goal of road reduction which, in turn, will have the benefit of producing less sediment that may impact our nation's waterways. 


\section{References}

Adams, T.O., Hook, D.D., and Floyd, M.A., 1995. Effectiveness monitoring of silvicultural best management practices in South Carolina. Southern Journal of Applied Forestry, 19(4): 170-176

Briggs, R.D., Cormier, J., and Kimball, A. 1998. Compliance with forestry best management practice in Maine. Northern Journal of Applied Forestry, 15(2): 5768.

Brynn, D.J., and Clausen, J.C. 1991. Postharvest assessment of Vermont's acceptable management practices and water quality impacts. Northern Journal of Applied Forestry, 8(4): 140-144.

Corbett, E., Lynch J., \& Sopper, W. 1978. Timber harvesting practices and water quality in the eastern United States. Journal of Forestry, 76(8): 484-488.

Dean, D.R. 2003. Proposed method to assess timber harvesting roads. Transportation Research Record, 1819(1): 127-131.

Edwards, P.J. and Stuart, G.W. 2002. State survey of silviculture nonpoint source programs: A comparison of the 2000 northeastern and national results. Northern Journal of Applied Forestry. 19(3) 122-127.

Egan, A.F. 1999. Forest roads: where soil and water don't mix. Journal of Forestry, 97(8): 18-21.

Egan, A.F., 1999. Reducing forest road erosion: Do foresters and logging contracts matter? Journal of Forestry, 97(8): 36-39.

Egan, A., Gibson, D., and Whipkey, R. 2001. Evaluating the effectiveness of the Forest Stewardship Program in West Virginia. Journal of Forestry, 99(3): 31-36.

Egan, A.F., Whipkey, R.D., and Rowe, J.P. 1998. Compliance with forestry best management practices in West Virginia. Northern Journal of Applied Forestry, 15(4): 211-215.

Eliot, W.J., and Tysdal, L.M. 1999. Understanding and reducing erosion from insloping roads. Journal of Forestry, 97(8): 30-34.

Griffith, D.M., and Widmann, R.H. 2003. Forest statistics for West Virginia: 1989 and 2000. USDA Forest Service Resource Bulletin NE-157. Northeastern Research Station, Newtown, PA. 
Hawks, L., Cubbage, F., Haney, Jr., H., Shaffer, R., \& Newman, D. 1993. Forest water quality protection: A comparison of regulatory and voluntary programs. Journal of Forestry, 91(5): 48-54.

Ice, G.G., Stuart, G., Waide, J., Irland, L., \& Ellefson, P. 1997. 25 years of the Clean Water Act: How clean are forest practices? Journal of Forestry, 95(7): 9-13.

Irland, L.C. and Connors, J.F. 1994. State nonpoint source programs affecting forestry: The 12 Northeastern States. Northern Journal of Applied Forestry, 11(1): 5-11.

Jennings, B. 2003. Implementation of recommended Forest Stewardship Program practices in West Virginia: Ten-year assessment. MS Thesis. Morgantown, WV. West Virginia University. 68p.

Kochenderfer, J.N. 1970. Erosion control on logging roads in the Appalachians. USFS Research Paper NE-158. Northeastern Forest Experiment Station, Randor, PA. $28 \mathrm{p}$.

Kochenderfer, J.N. 1977. Area in skidroads, truck roads, and landings in the central Appalachians. Journal of Forestry, 75(8): 507-508

Kochenderfer, J.N., Edwards, P.J., and Wood, F. 1997. Hydrologic impacts of logging an Appalachian watershed using West Virginia's best management practices. Northern Journal of Applied Forestry, 14(4): 207-218.

Lickwar, P.M, Cubbage, F.W., and Hickman, C.A. 1990. Current Southern State programs for control of forestry nonpoint source pollution. Southern Journal of Applied Forestry, 14(2): 64-69

Lockaby, B.G., and Rummer, R. 1996. Impacts of harvesting in wetlands. Forest Landowner, 55(6): 24-27.

Luce, C.H., and Black, T.A. 1999. Sediment production from forest roads in western Oregon. Water Resources Research, 35(8): 2561-2570.

Lynch, J., and Corbett, E. 1990. Evaluation of best management practices for controlling nonpoint pollution from silvicultural operations. Water Resources Bulletin, 26(1): 41-52.

Lynch, J.A., Corbett, E.S., and Mussallem, K. 1985. Best management practices for controlling nonpoint-source pollution on forested watersheds. Journal of Soil and Water Conservation. 40(1): 164-167.

Martin, C.W., and Hornbeck, J.W. 1994. Logging in New England need not cause sedimentation of streams. Northern Journal of Applied Forestry, 11(1): 17-23. 
Melfi, F.M., Straka, T.J, Marsinko, A.P., and Baumann, J.L. 1997. Landowner attitudes toward South Carolina's Forest Stewardship Program. Southern Journal of Applied Forestry, 21(4): 158-163.

Moyers, B. 2002. Troubled Waters. Retrieved March 1, 2004 from the World Wide Web: http://www.pbs.org/now/science/cleanwater.html

Muskie, Edmund S. 1978. The meaning of the 1977 Clean Water Act. Retrieved January 12, 2004 from the World Wide Web: http://www.epa.gov/history/topics/cwa/04.htm

Patric, J.H. 1976. Soil erosion in the eastern forest. Journal of Forestry, 74(10): 671677.

Roach, B.A. 1977. A stocking guide for Allegheny hardwoods and its use in controlling intermediate cuttings. USFS Research Paper NE-373. Northeastern Forest Experiment Station, Upper Darby, PA. 30p.

Reinhart, K.R., Eschner, A.R., and Trimble, G.R. Jr. 1963. Effect on streamflow of four forest practices in the mountains of West Virginia. USDA For. Serv. Res. Pap. NE-1. 79p.

Swift, L.W. Jr. 1984. Gravel and grass surfacing reduces soil loss from mountain roads. Forest Roads, 30(3): 657-670.

United States Department of Agriculture. 2001. 2001 Status Report: Forest Stewardship Program. Forest Service, Northeastern Area.

USDA Natural Resources Conservation Service. 1998. Soil Survey of Webster County, West Virginia. 159p.

United States Environmental Protection Agency. Clean Water act. Retrieved from the World Wide Web: http://www.epa.gov/region5/water/cwa.htm

West Virginia's Forest Stewardship Program. n.d. WVDOF-MP-95-1. West Virginia Division of Forestry. Charleston, WV. 5p.

Whipkey, R.D. 1990. A comparison of nonpoint source sediment impact from various contributing sources on the 51 most heavily sediment impacted streams in West Virginia. WVDOF-TR 90-5. West Virginia Division of Forestry. Charleston, WV. $18 \mathrm{p}$.

Whipkey, R.D. 1991. An evaluation of the use and effectiveness of best management practices to control nonpoint sediment from logging operations in West Virginia. WVDOF 91-3. West Virginia Division of Forestry. Charleston, WV. 45 p. 
Wynn, T.M, Mostaghimi, S., Frazee, J.W., McClellan, P.W., Shaffer, R.M., \& Aust, W.M. 2000. Effects of forest harvesting best management practices on surface water quality in the Virginia coastal plain. Transactions of the ASAE, 43(4): 927936.

WVDOF-TR-96-3. 2002. Best Management Practices for Controlling Erosion and Sedimentation. Charleston, WV. 29p. 
Appendix A: Skid road layout maps for sites used in this study 


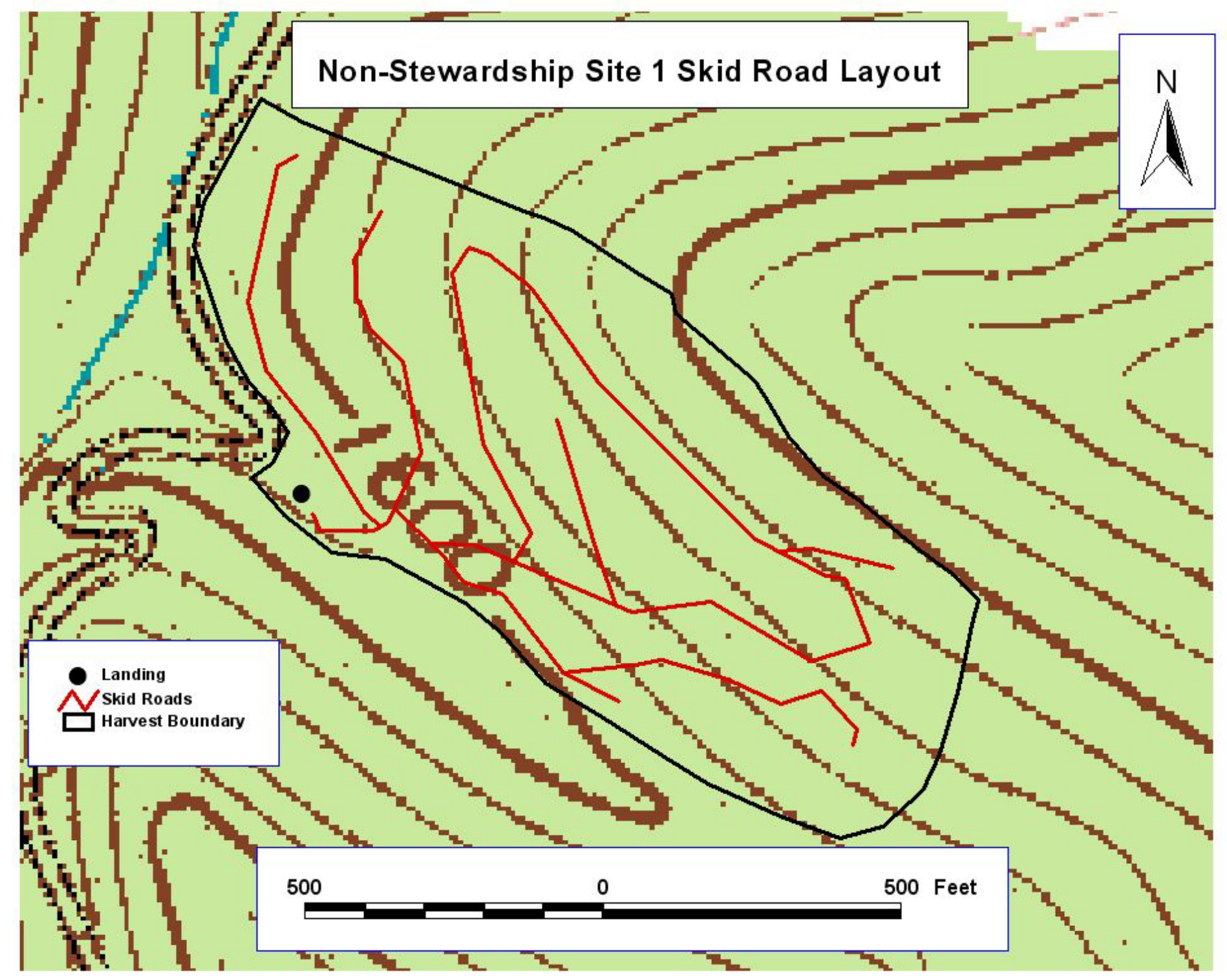




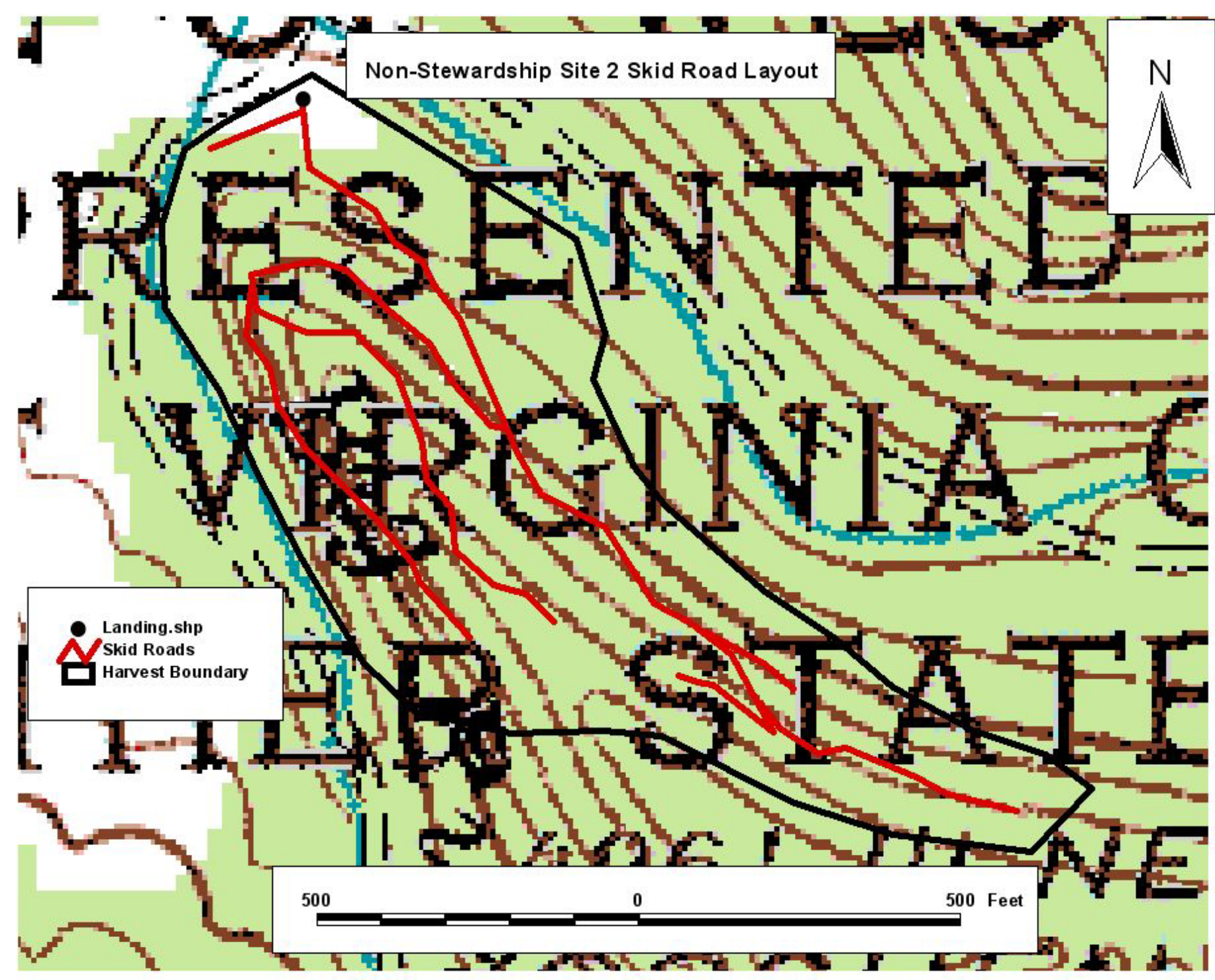




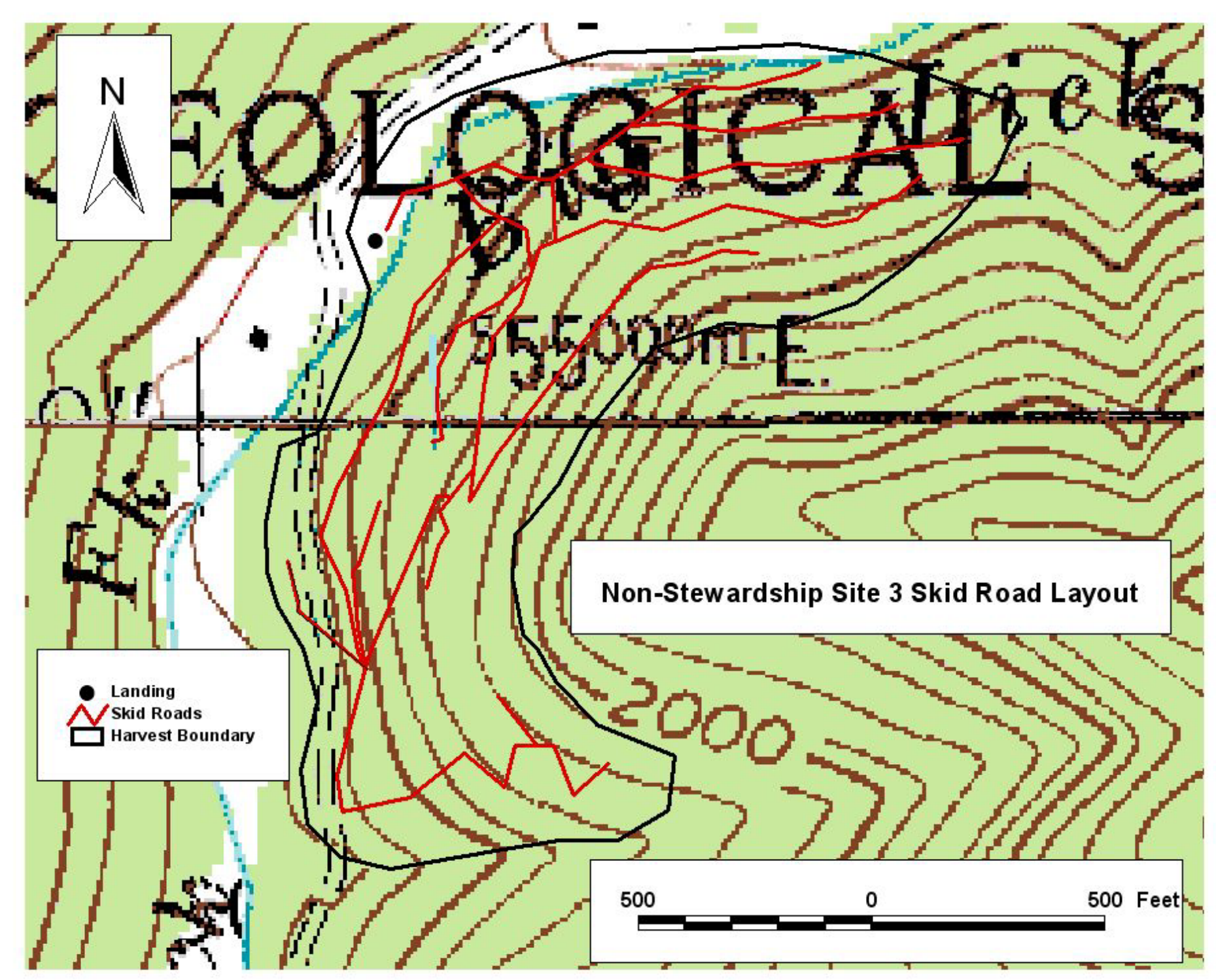




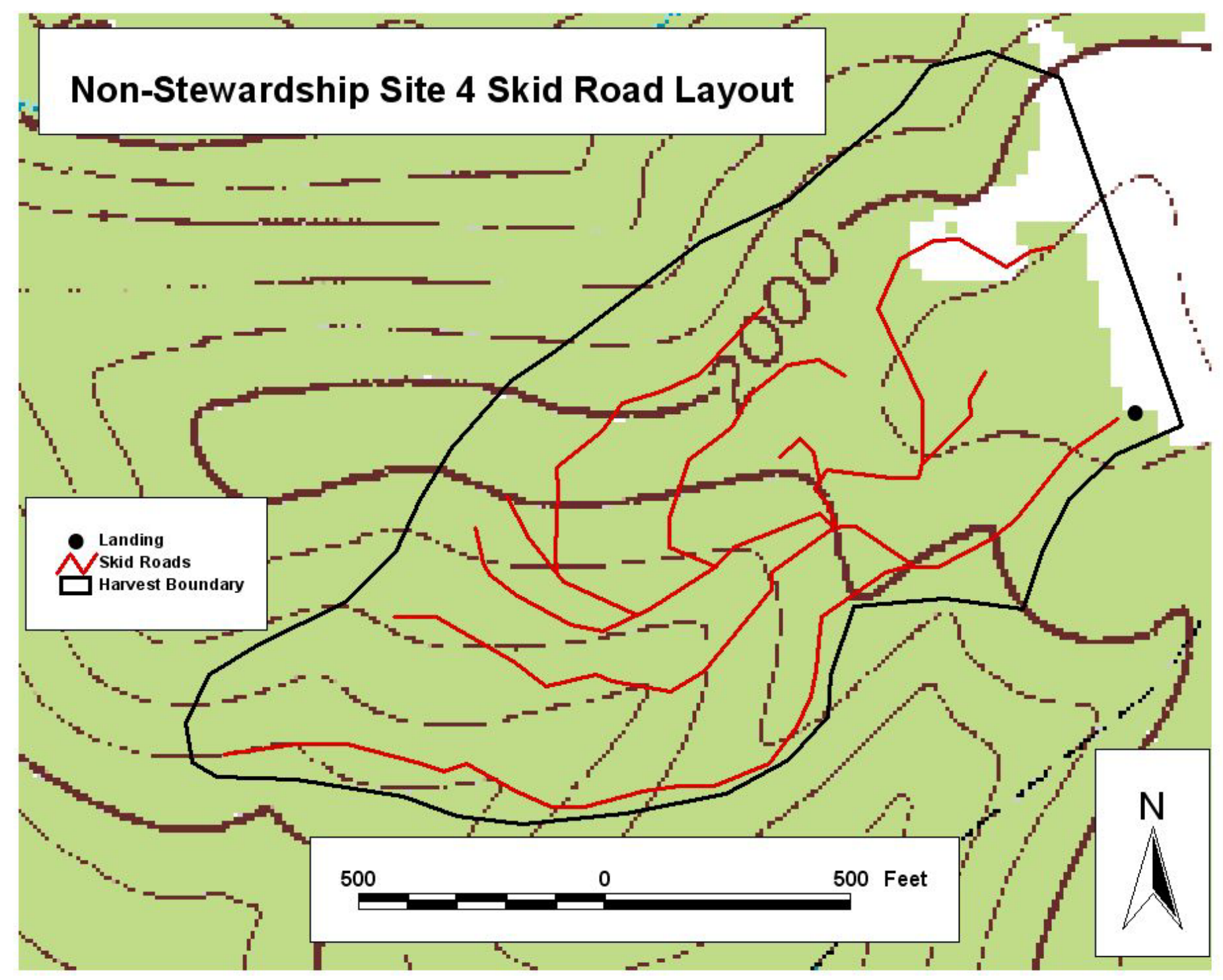




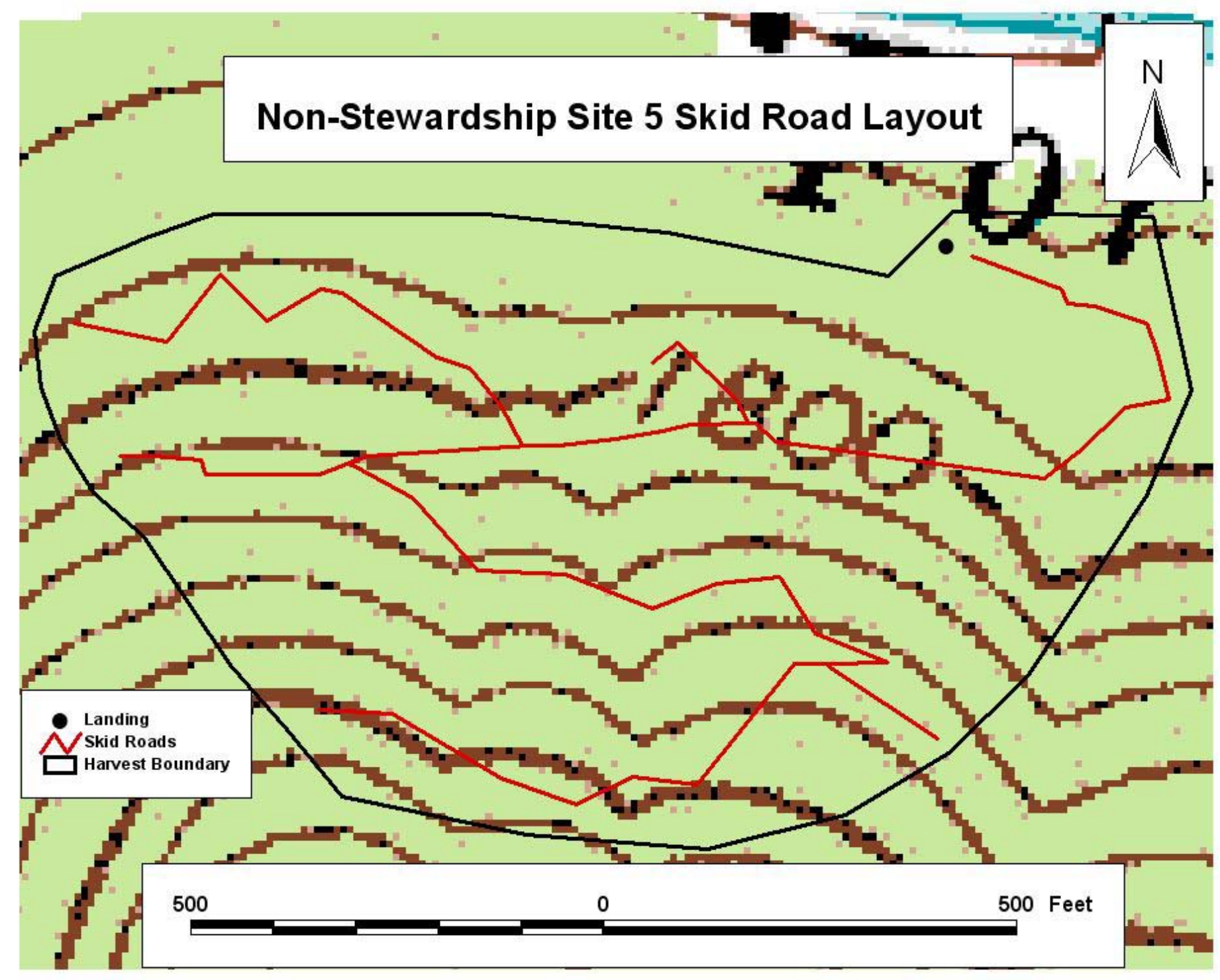




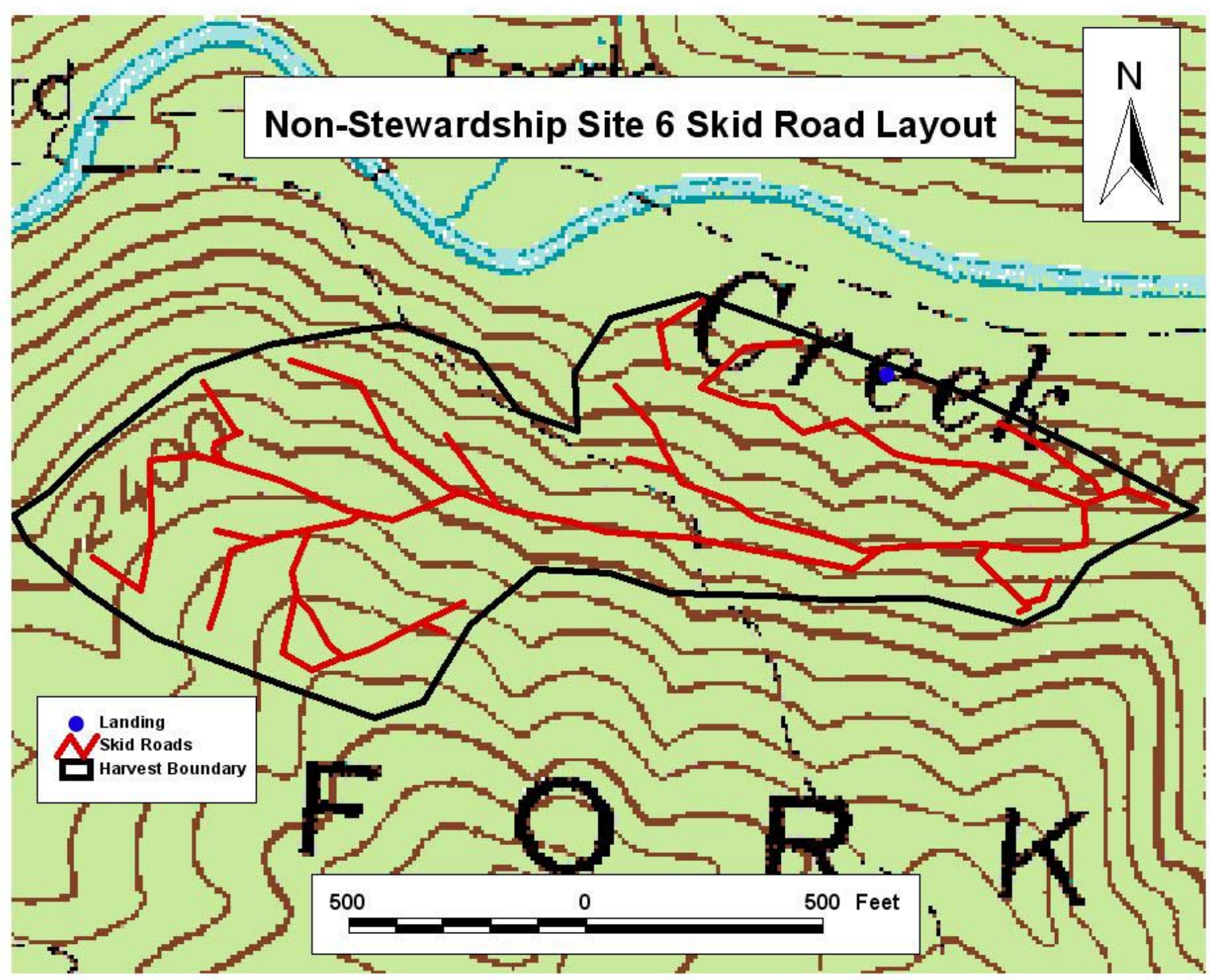




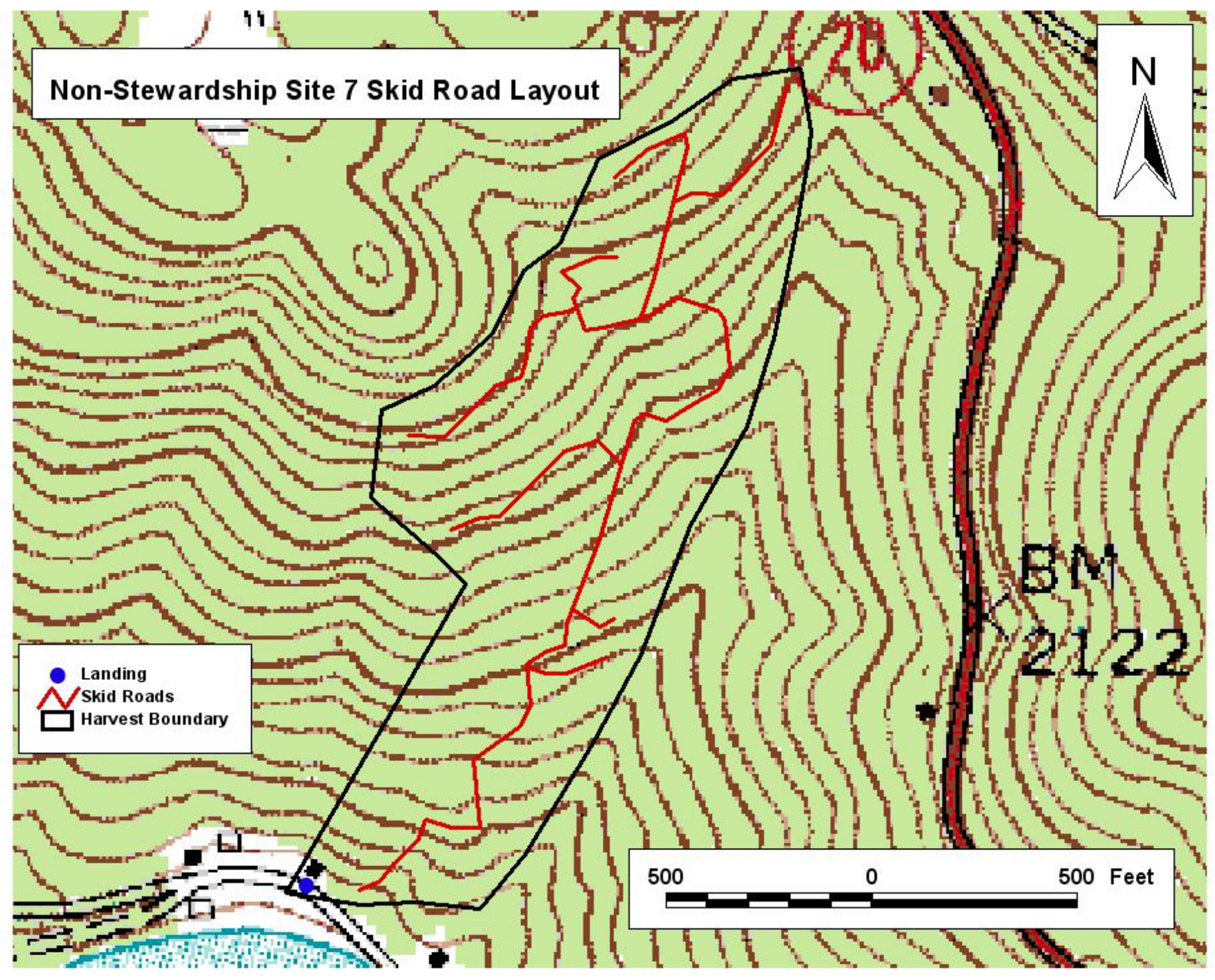




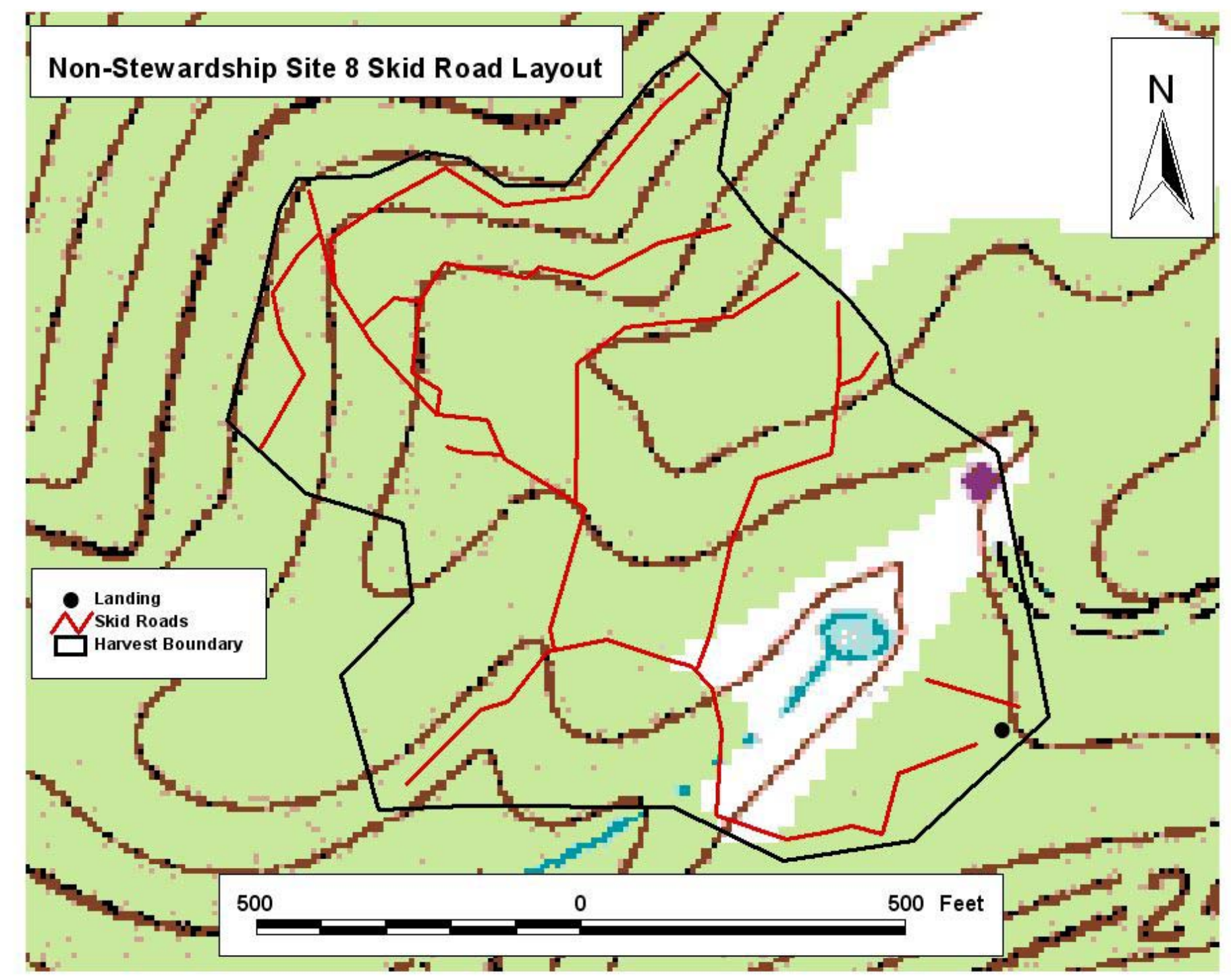




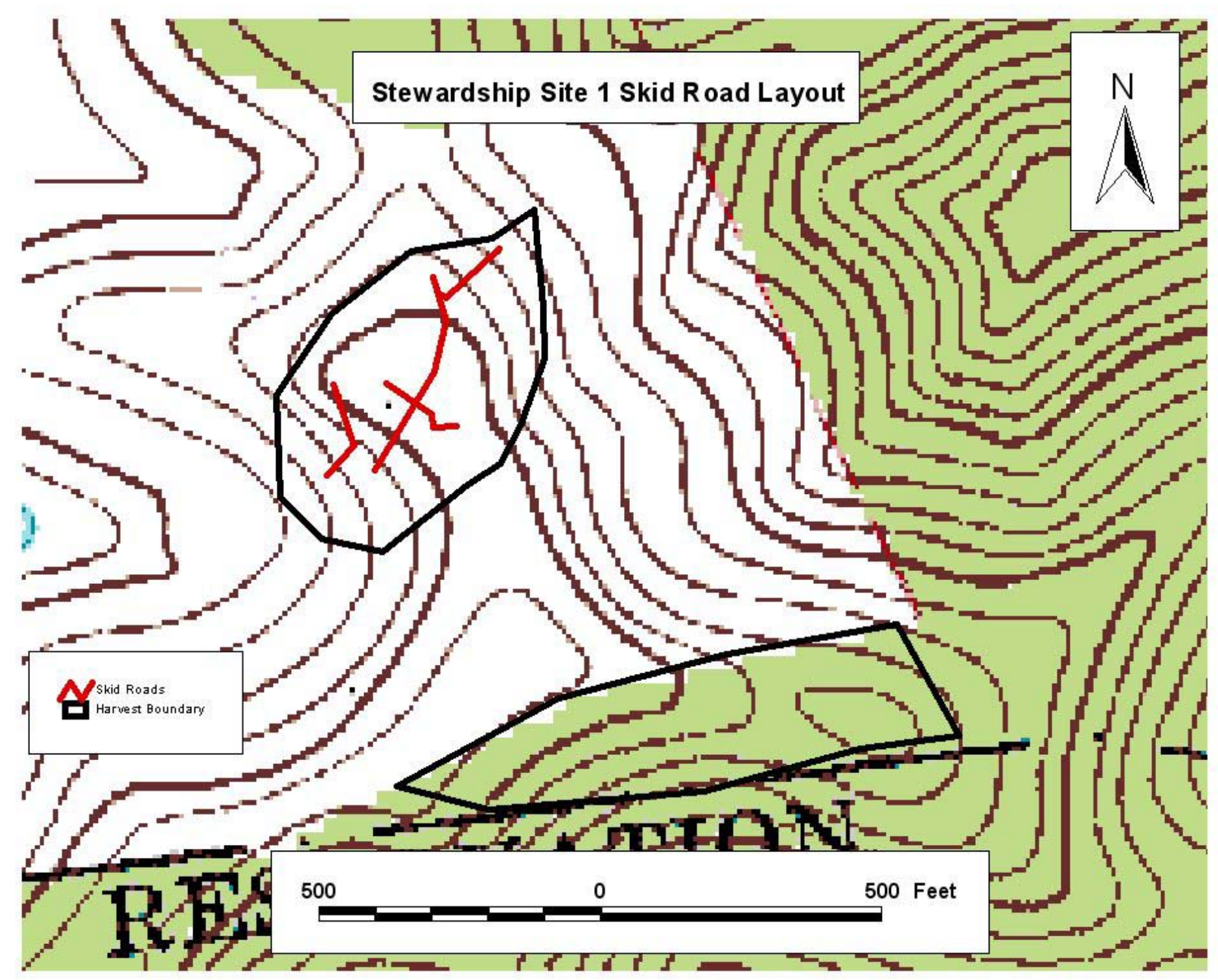




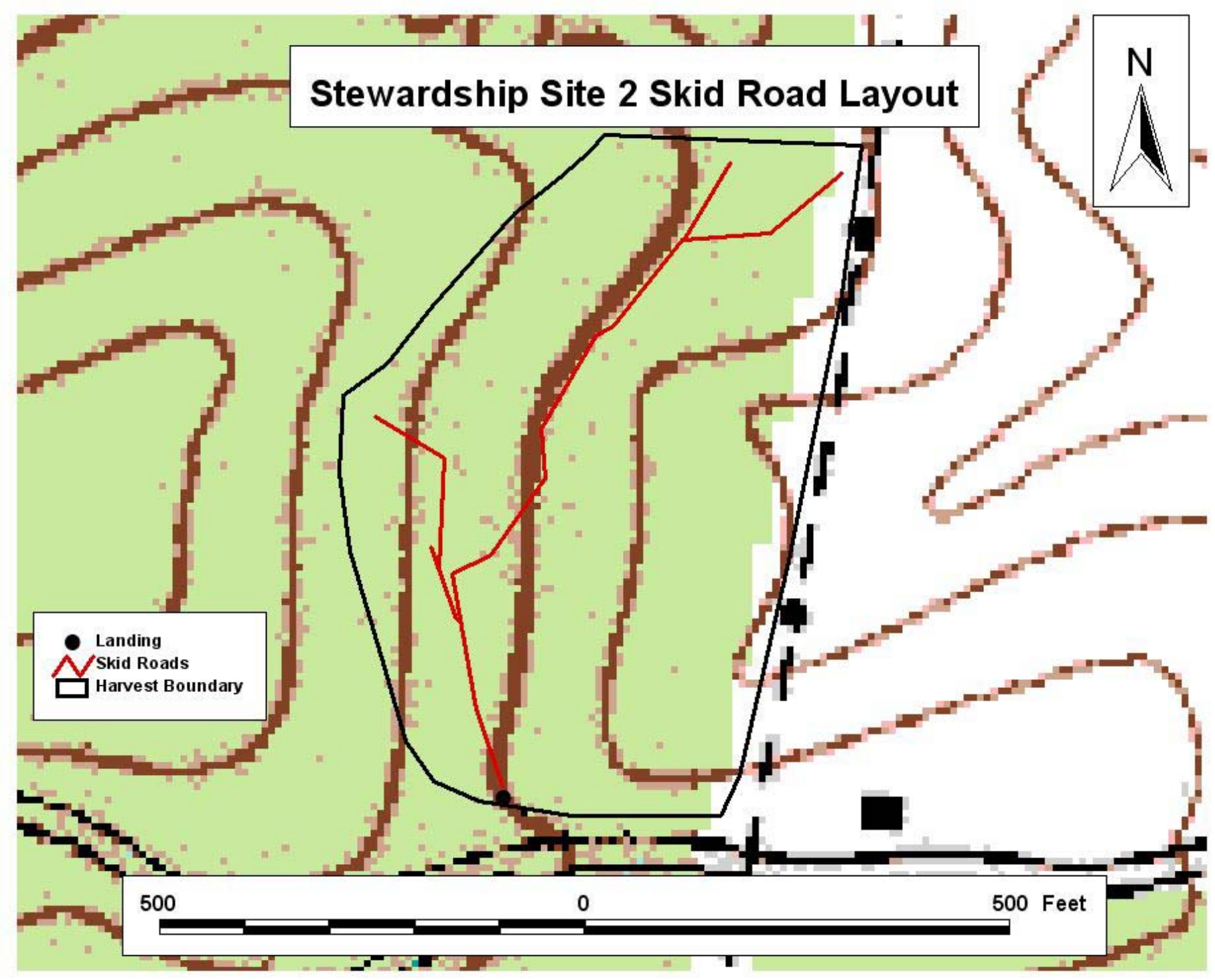









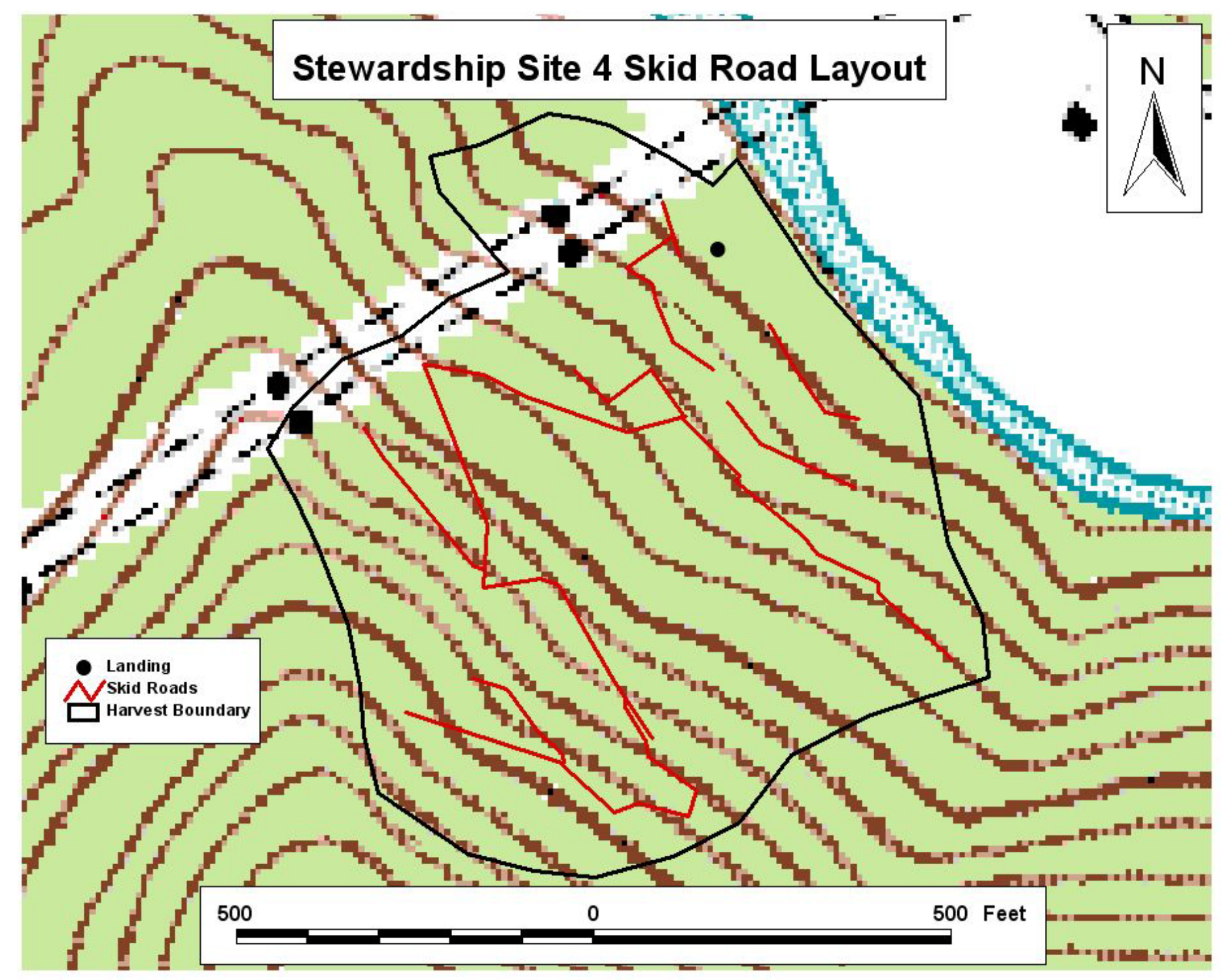




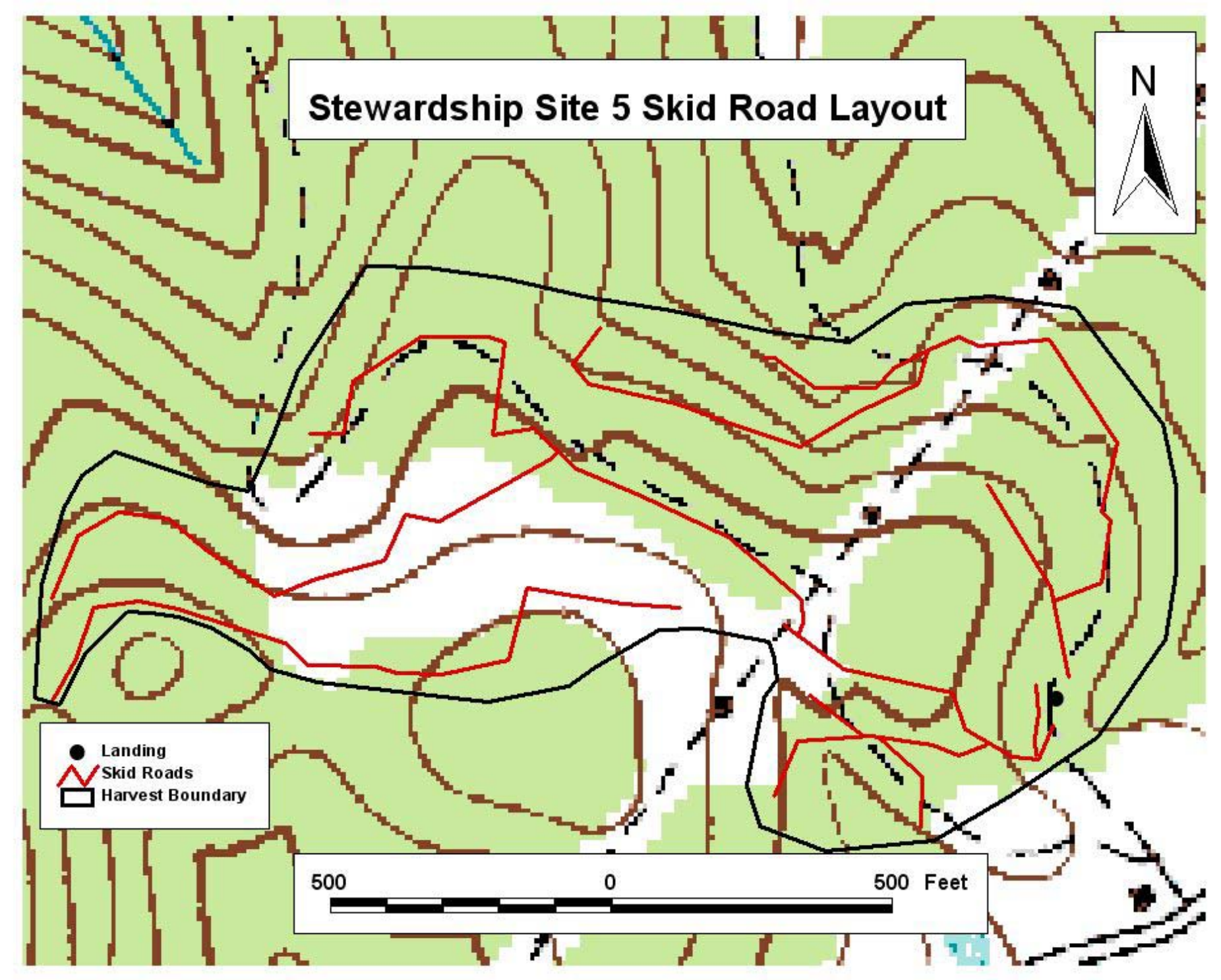




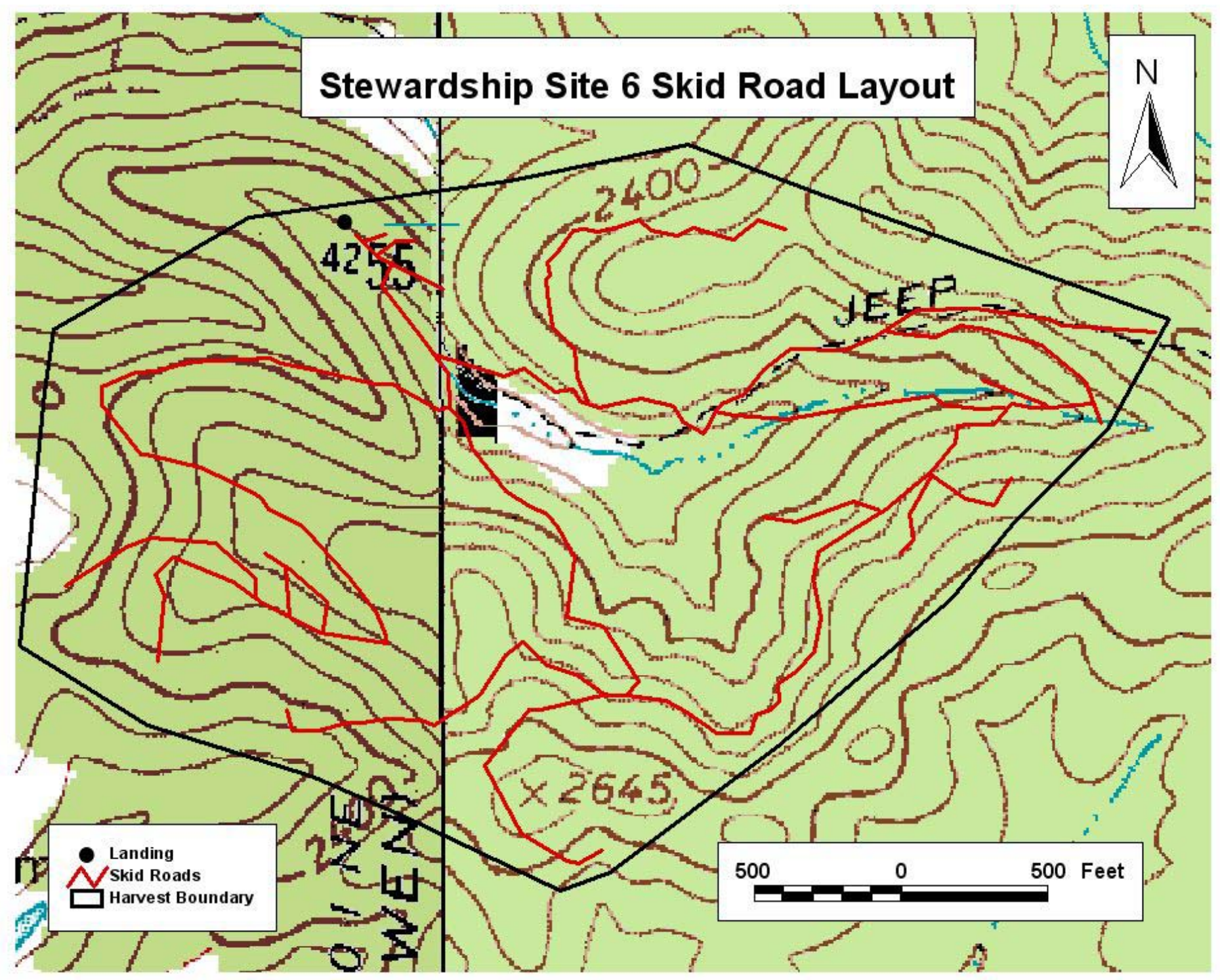




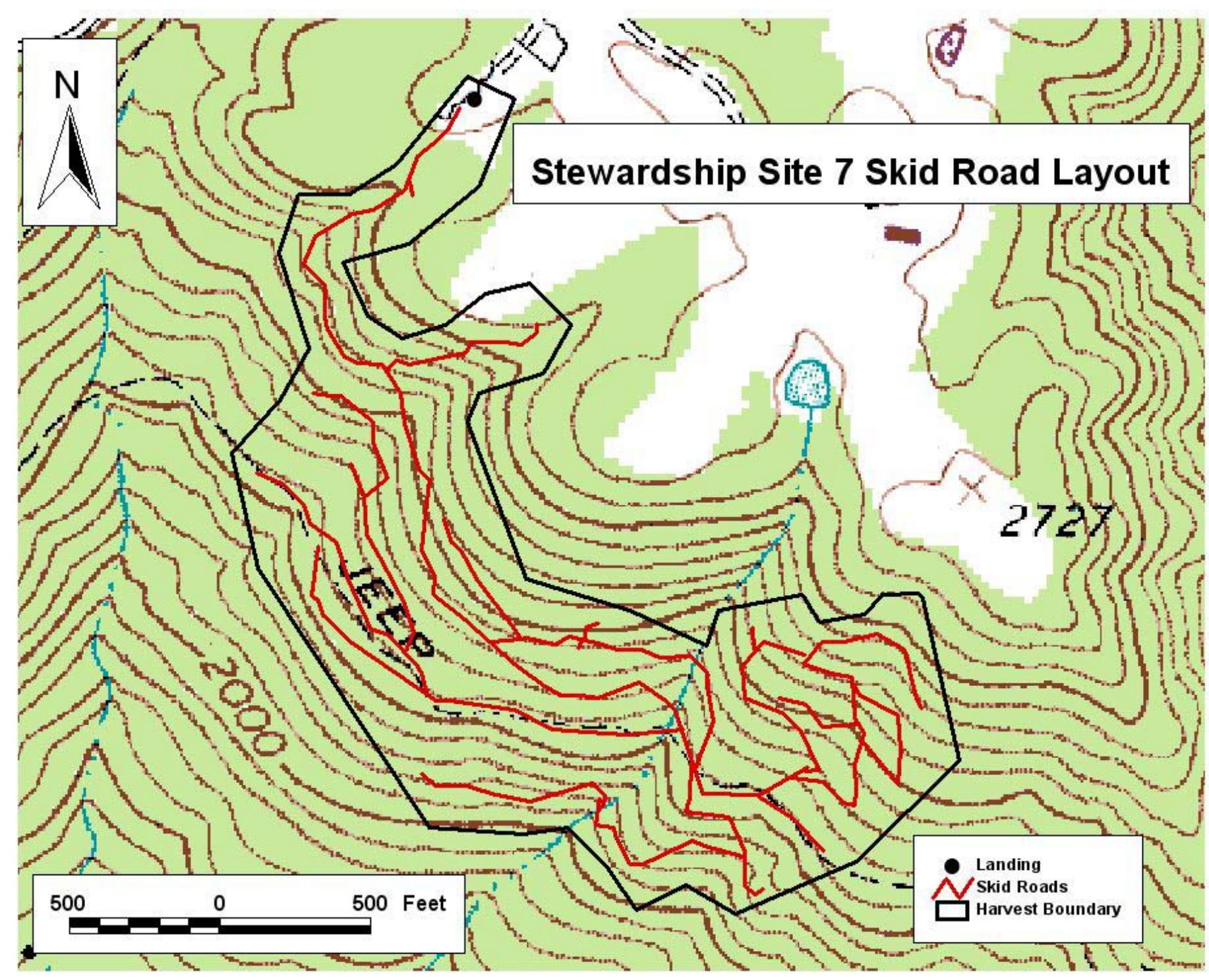


Appendix B: Reach capacity maps for sites used in this study 


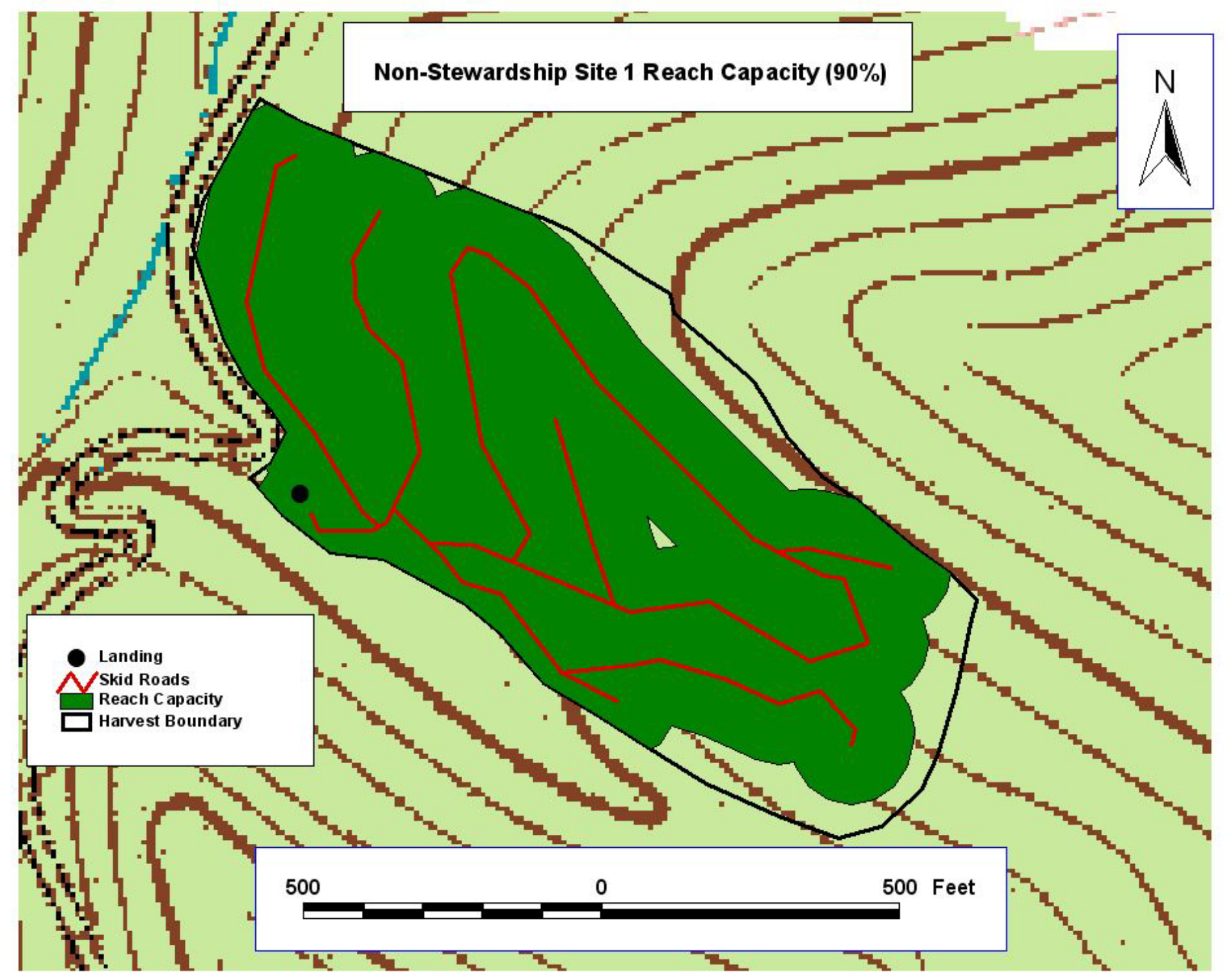




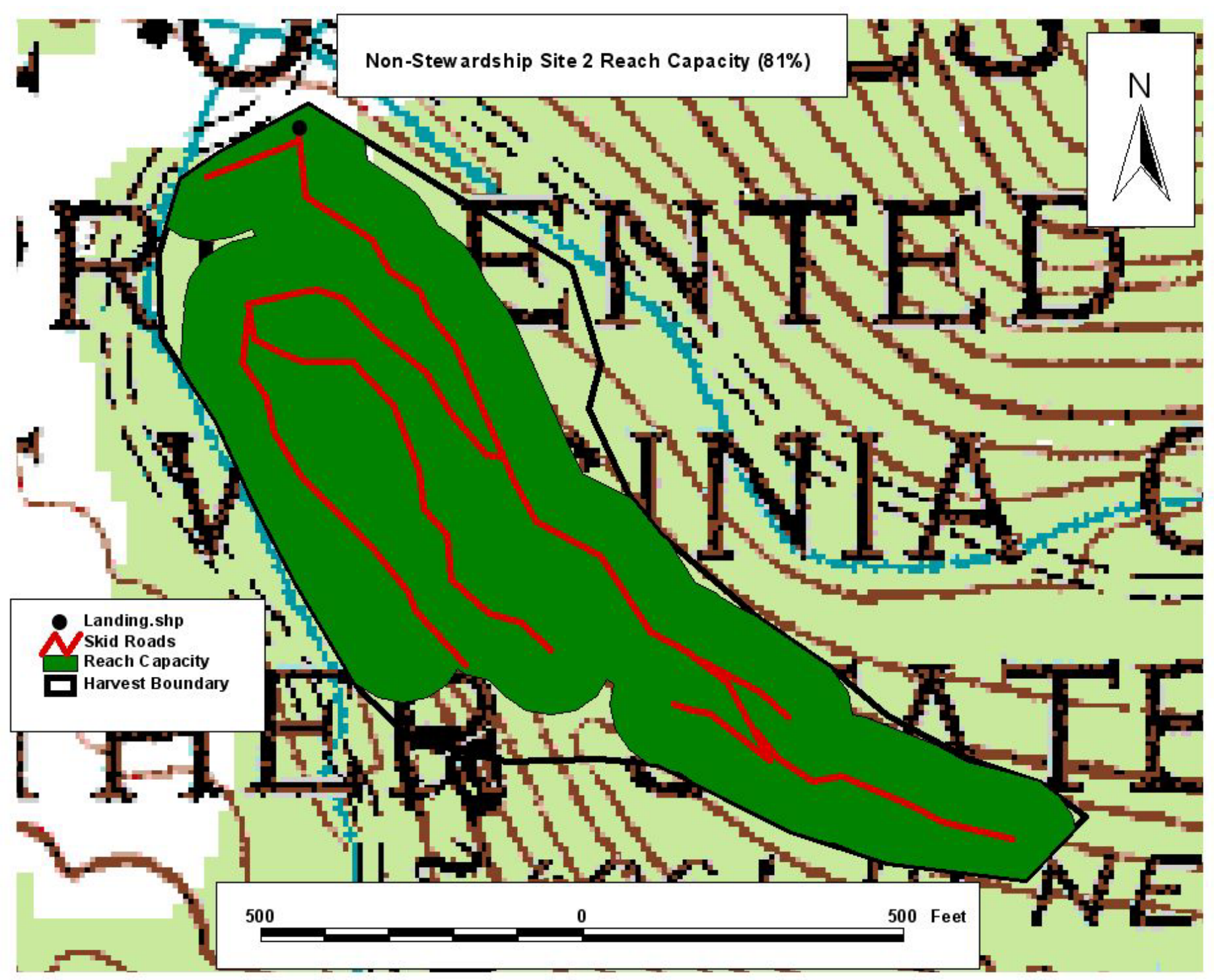




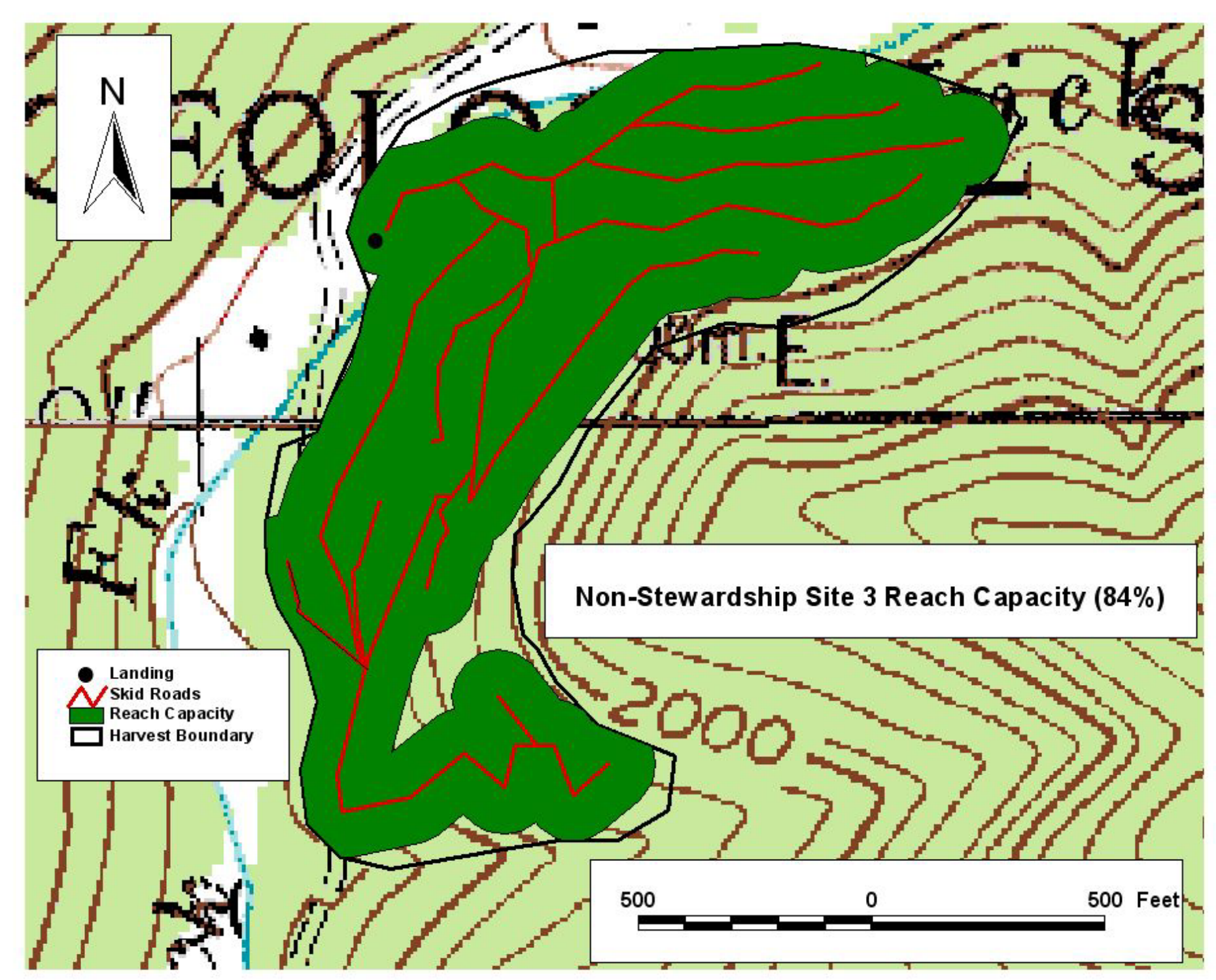




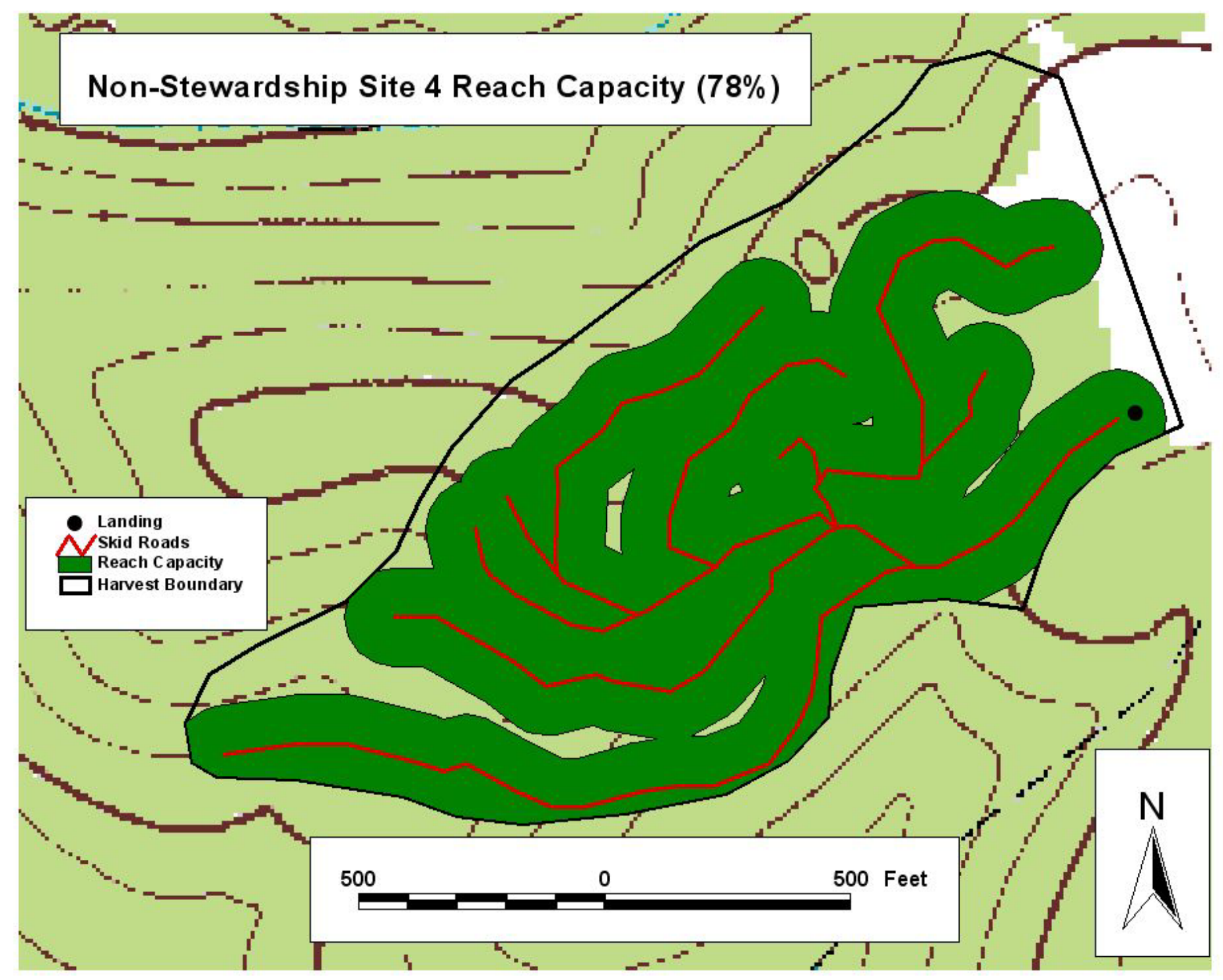




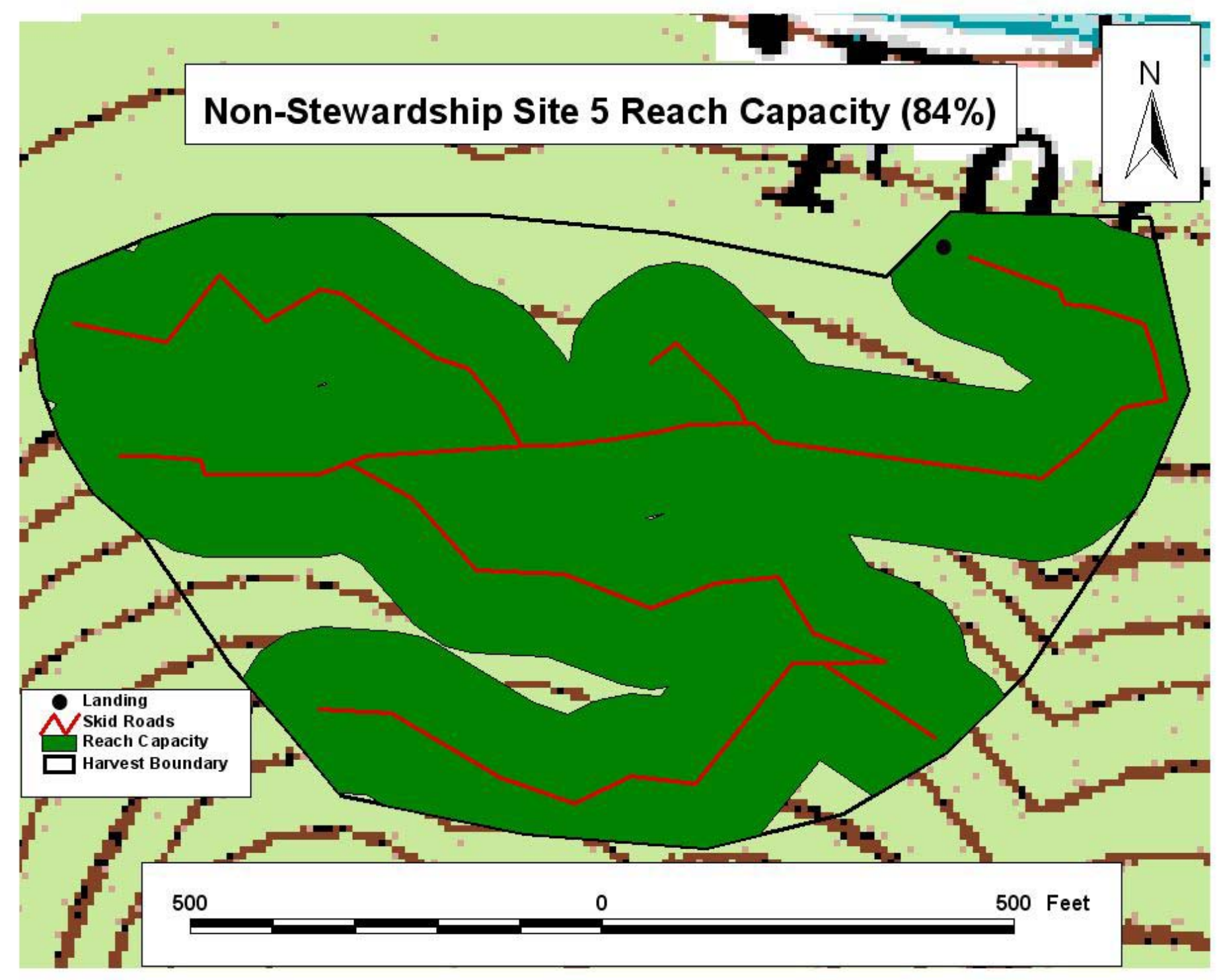




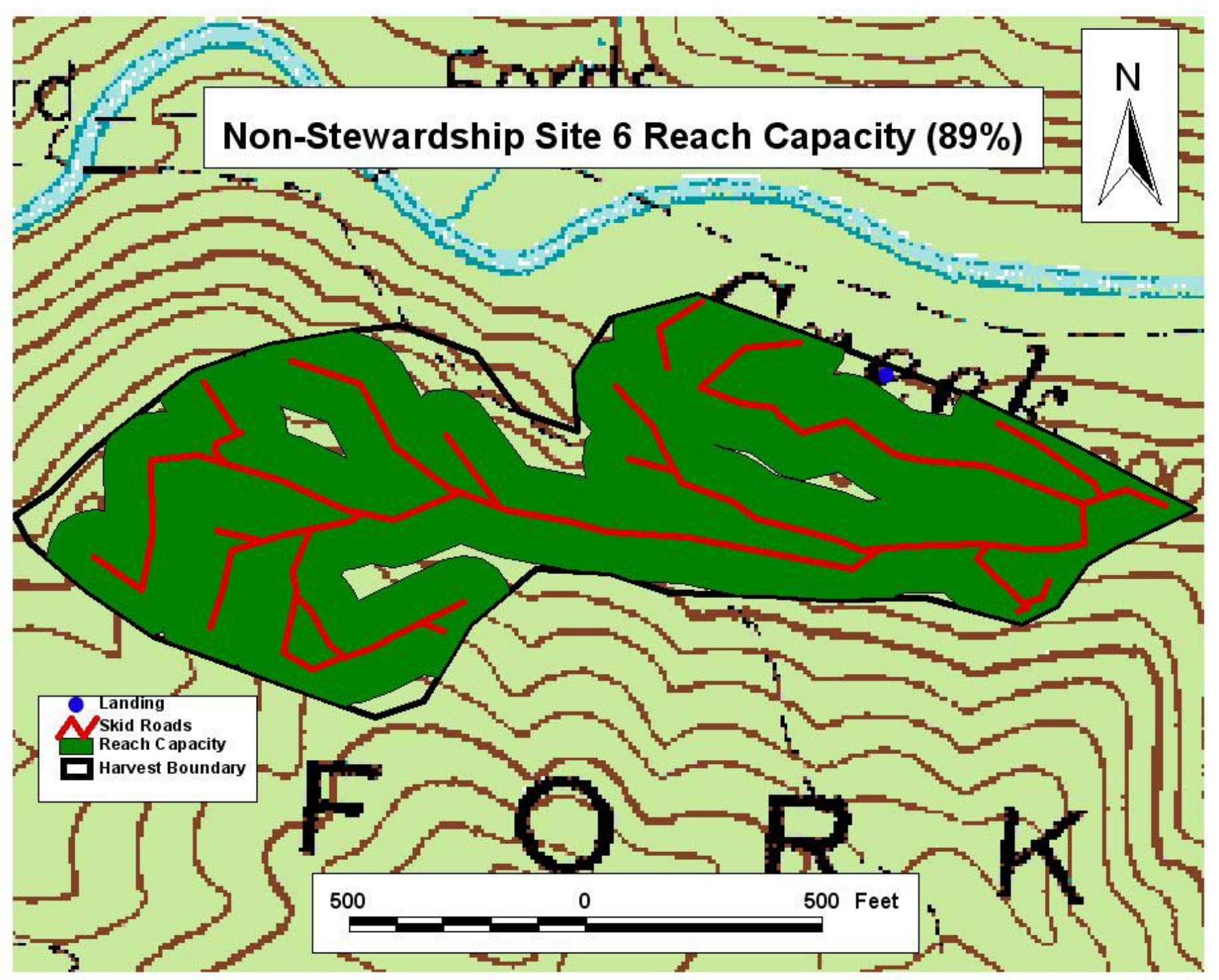




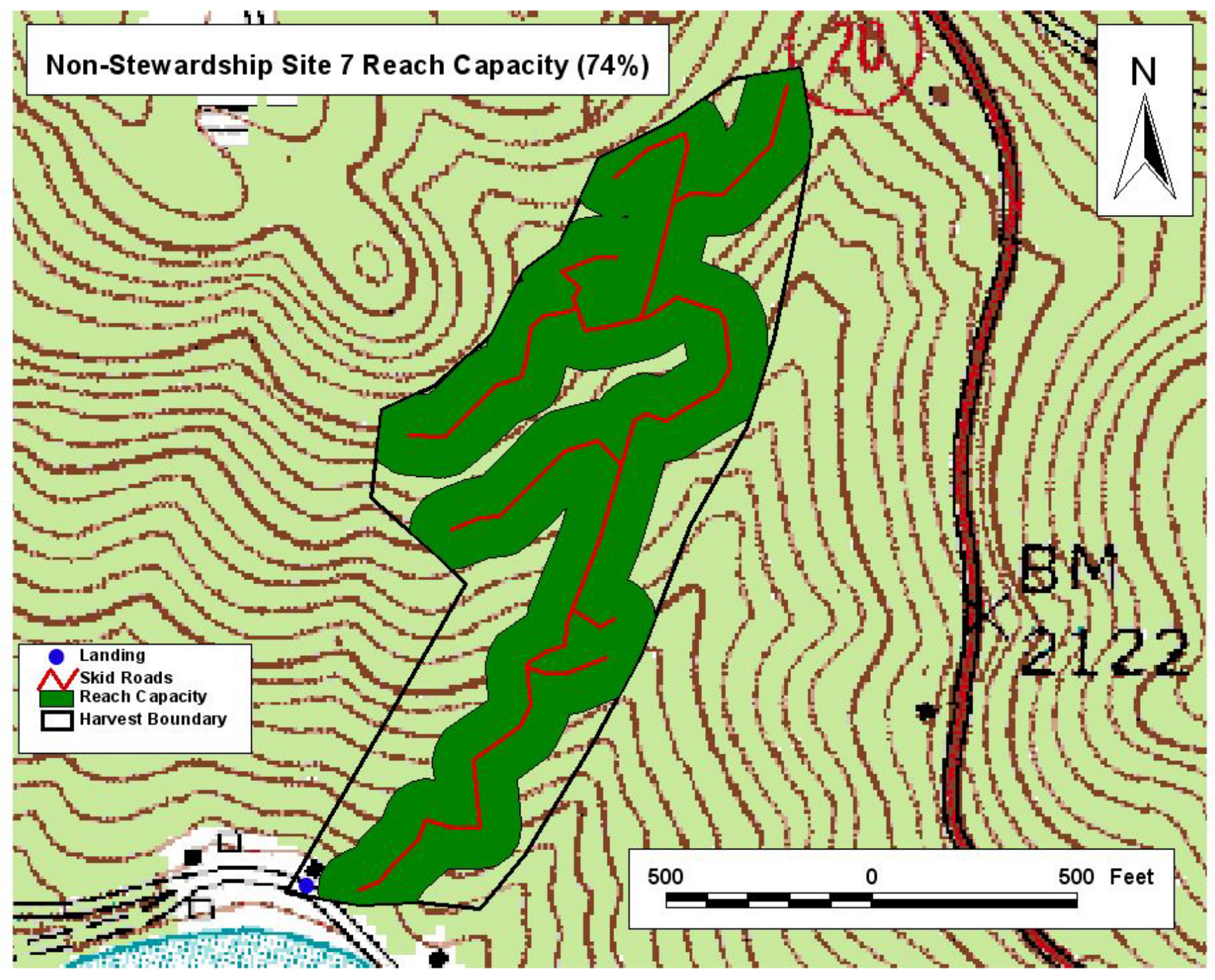




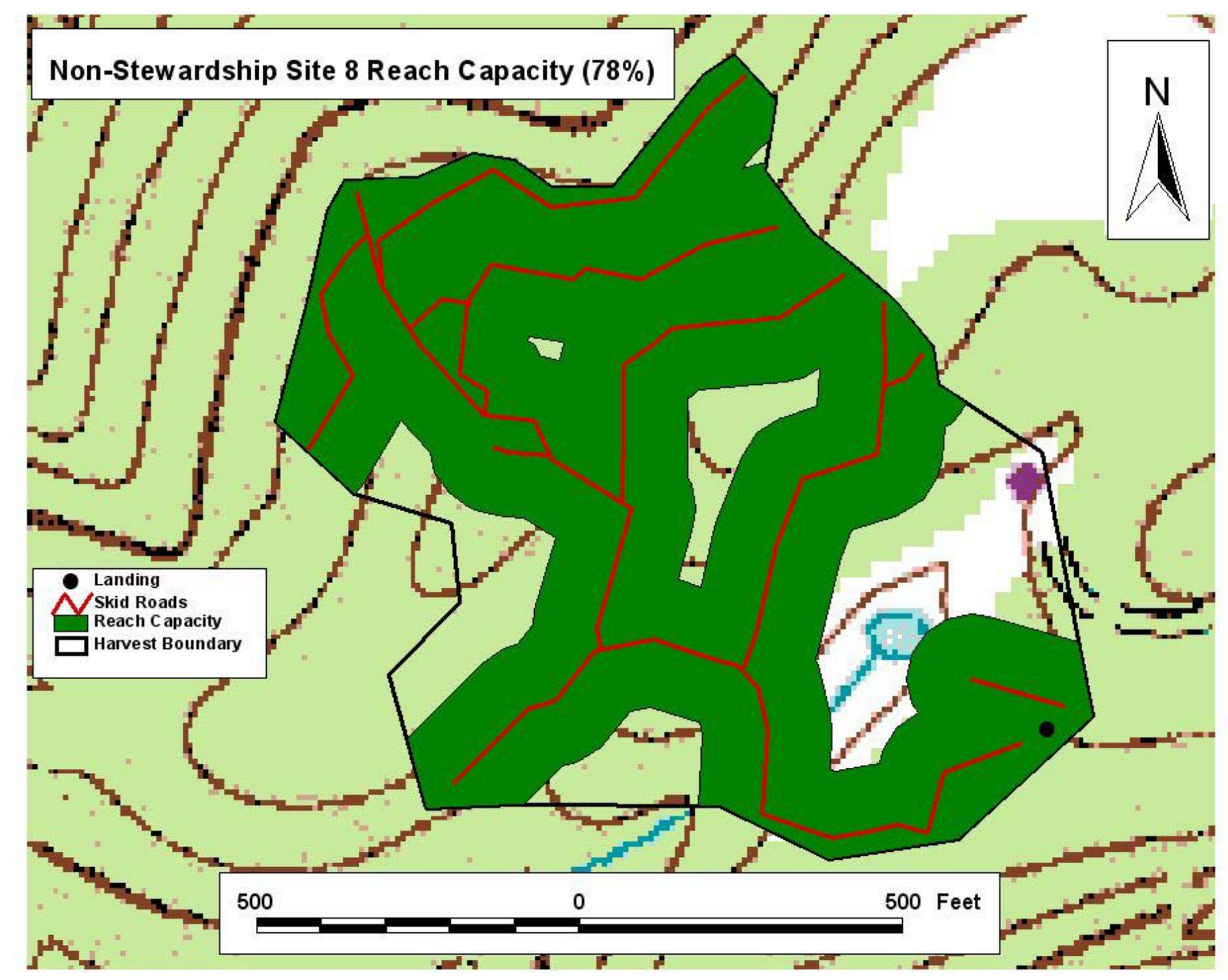




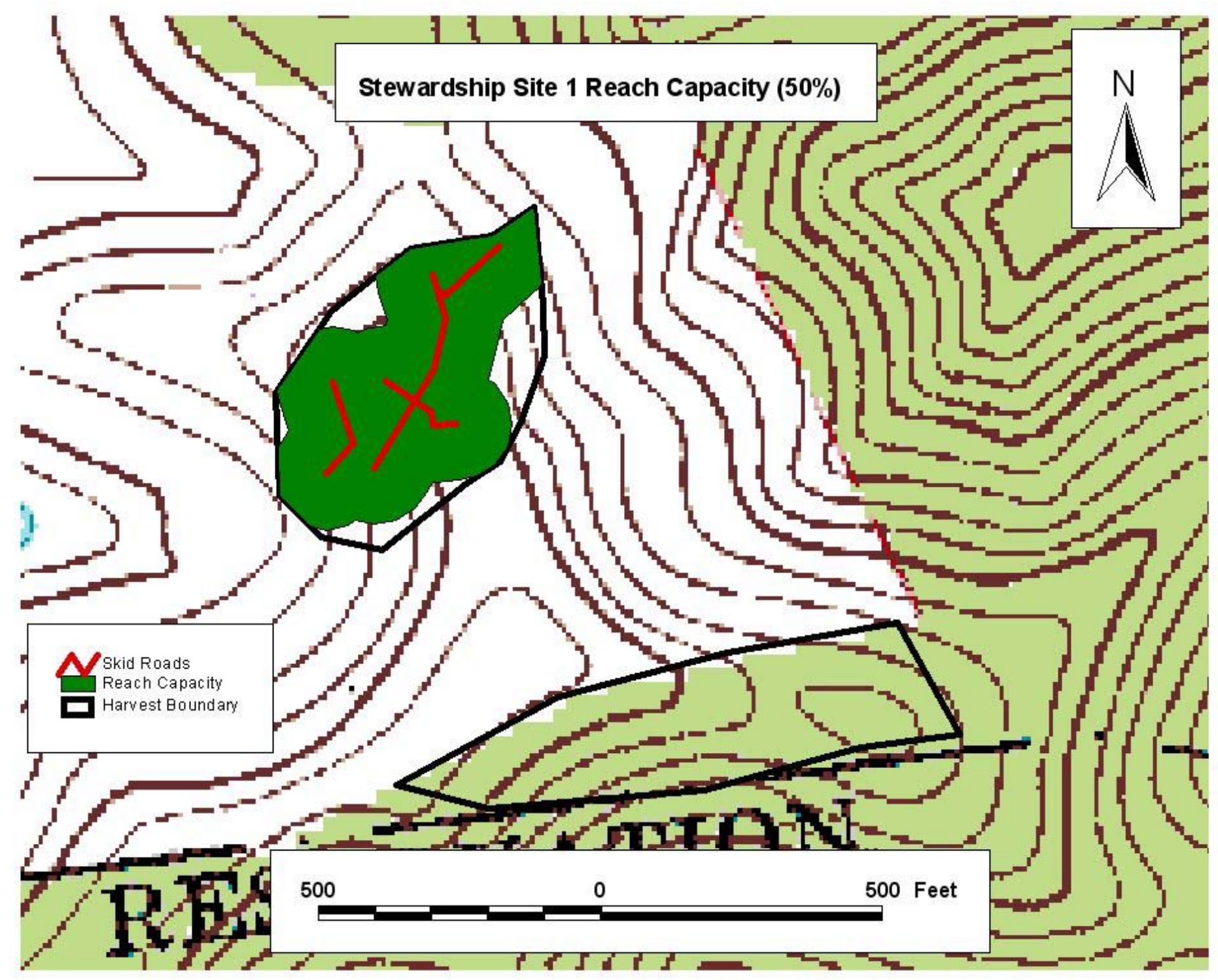




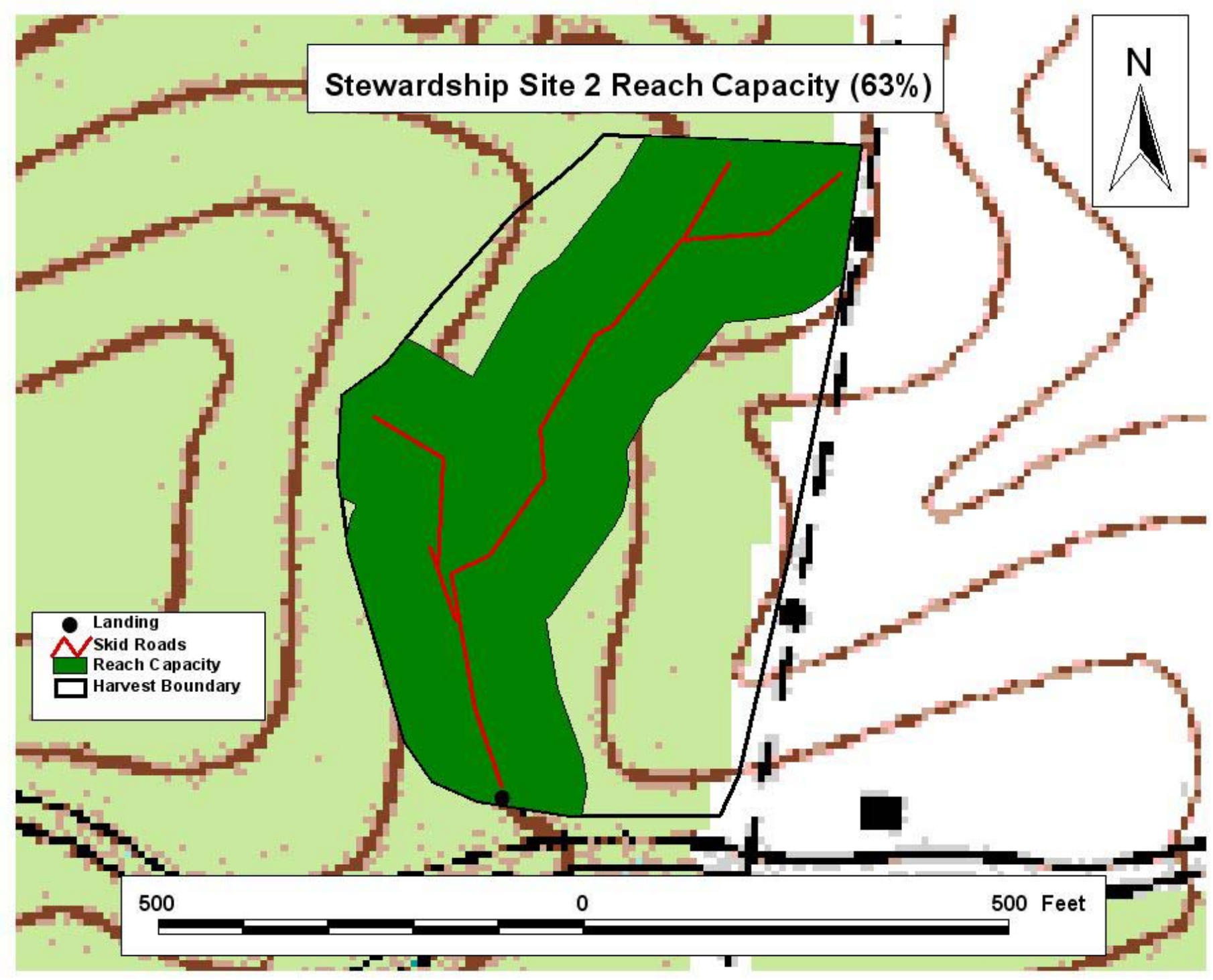




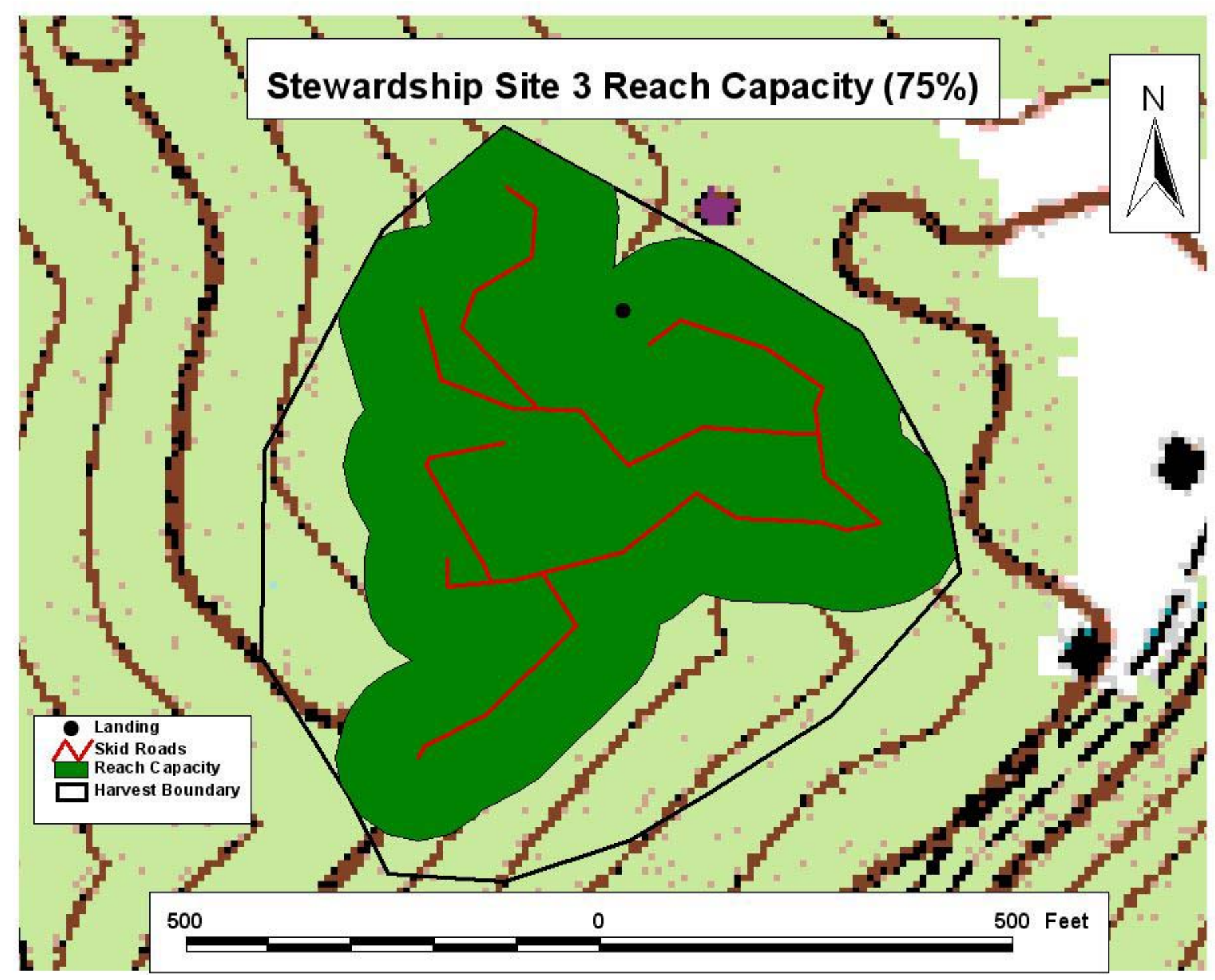




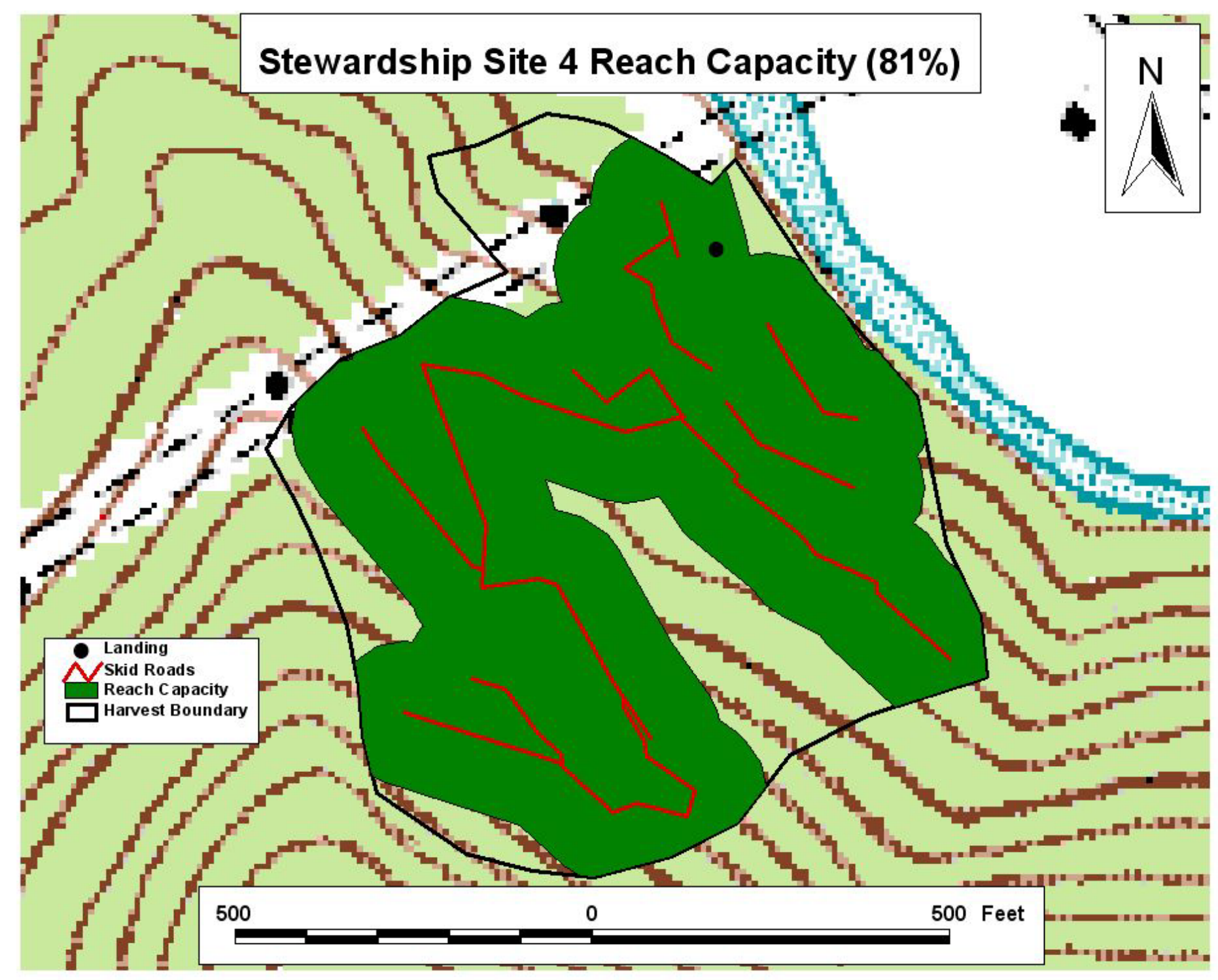




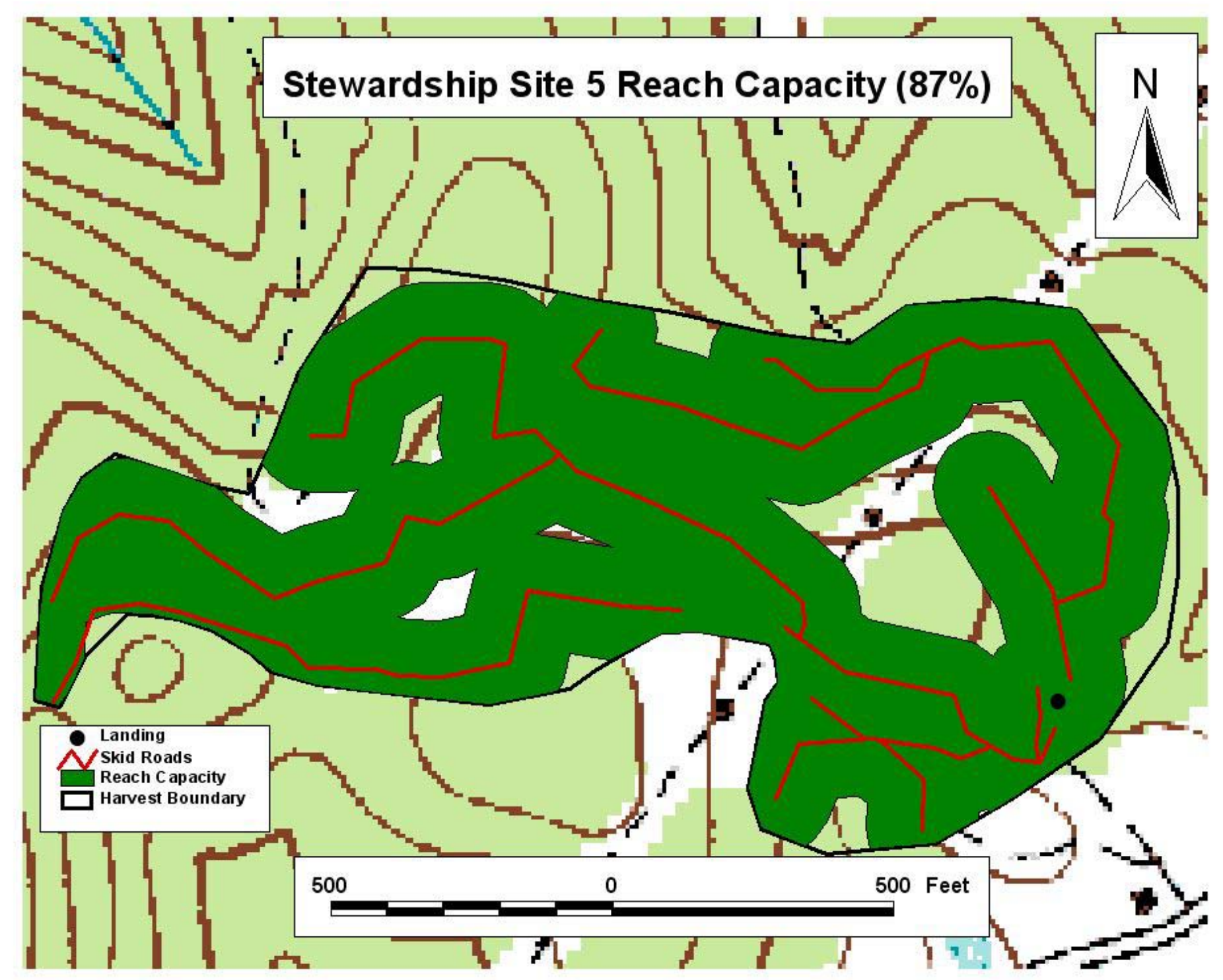




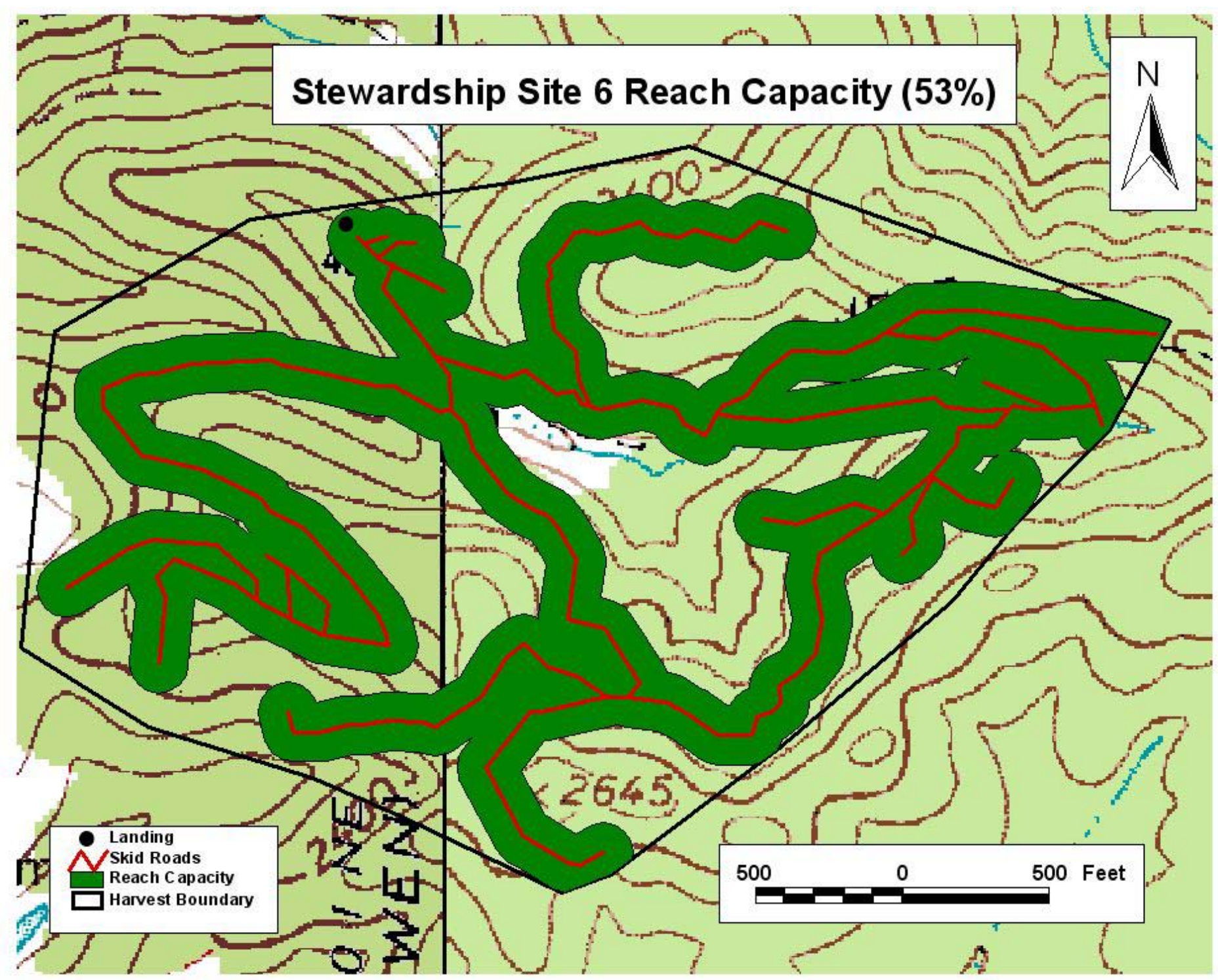




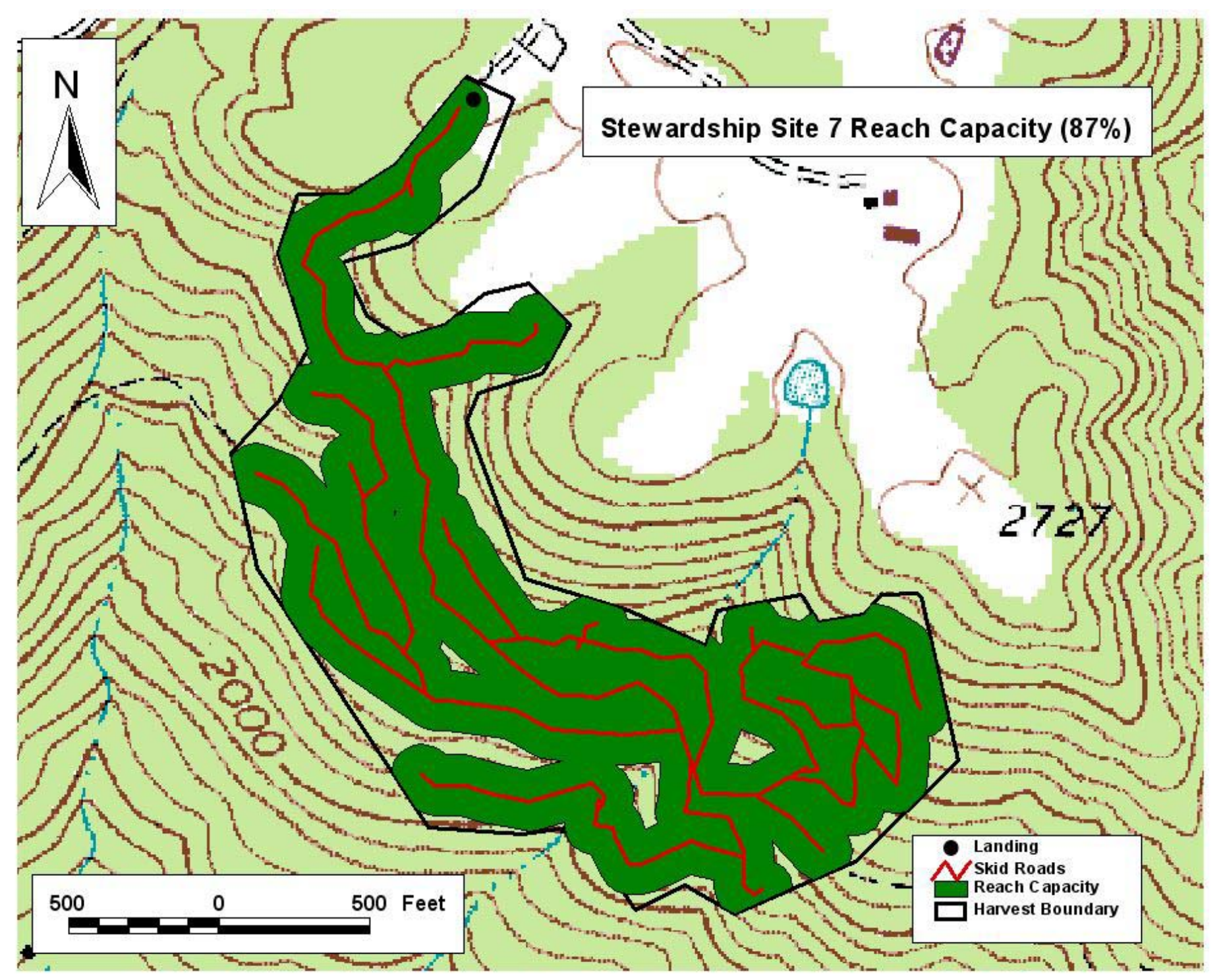


Appendix C: Excess reach capacity maps for sites used in this study 


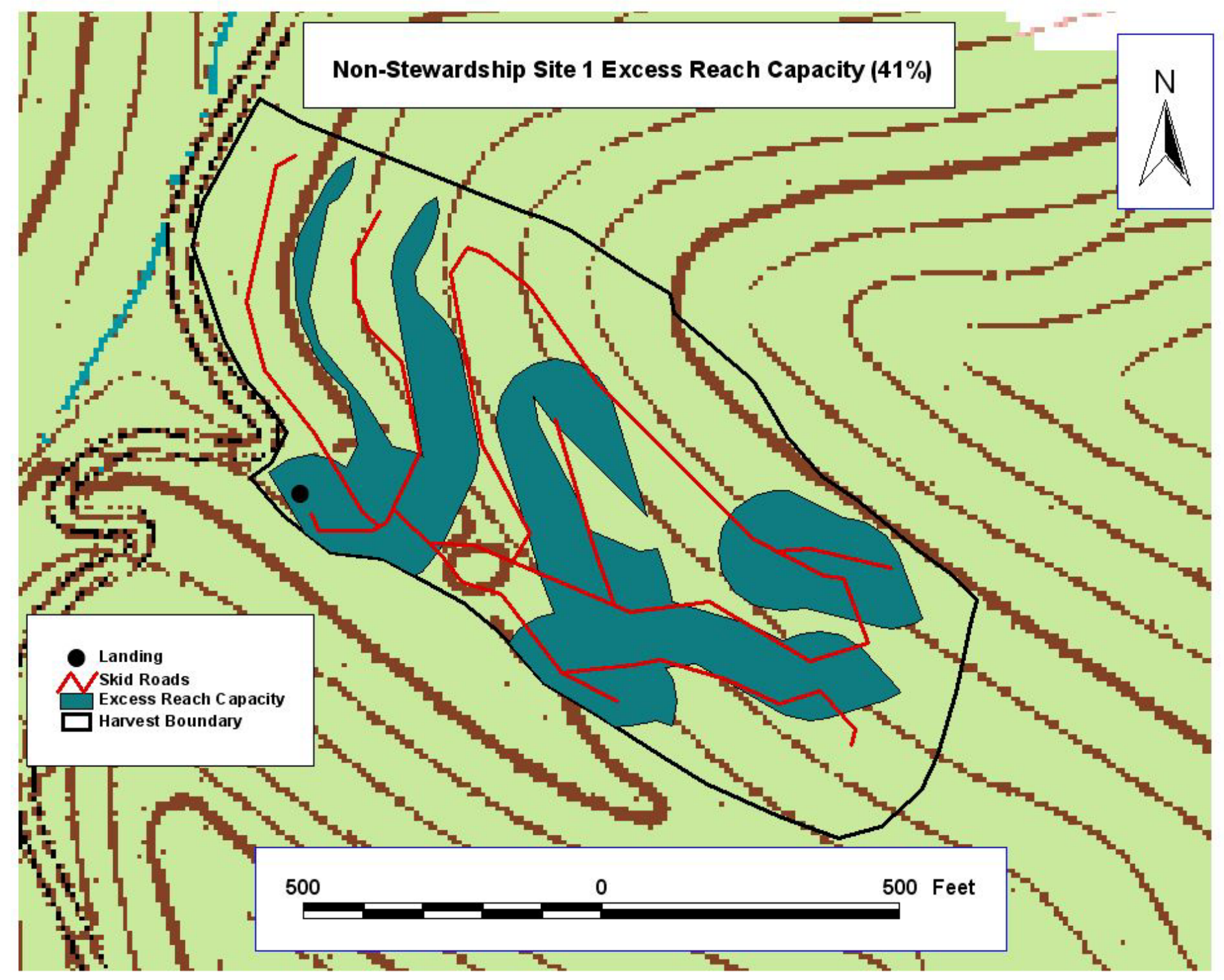




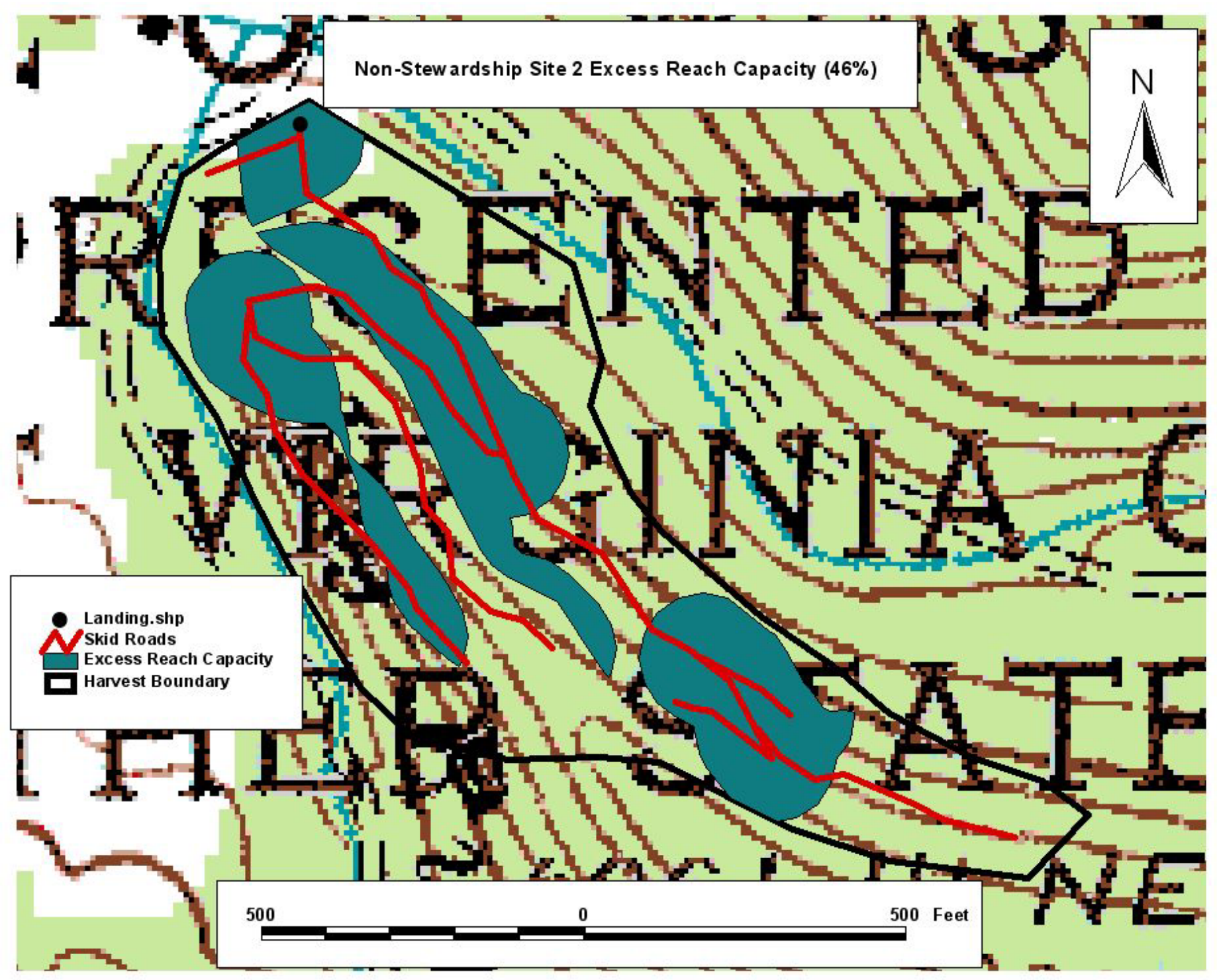




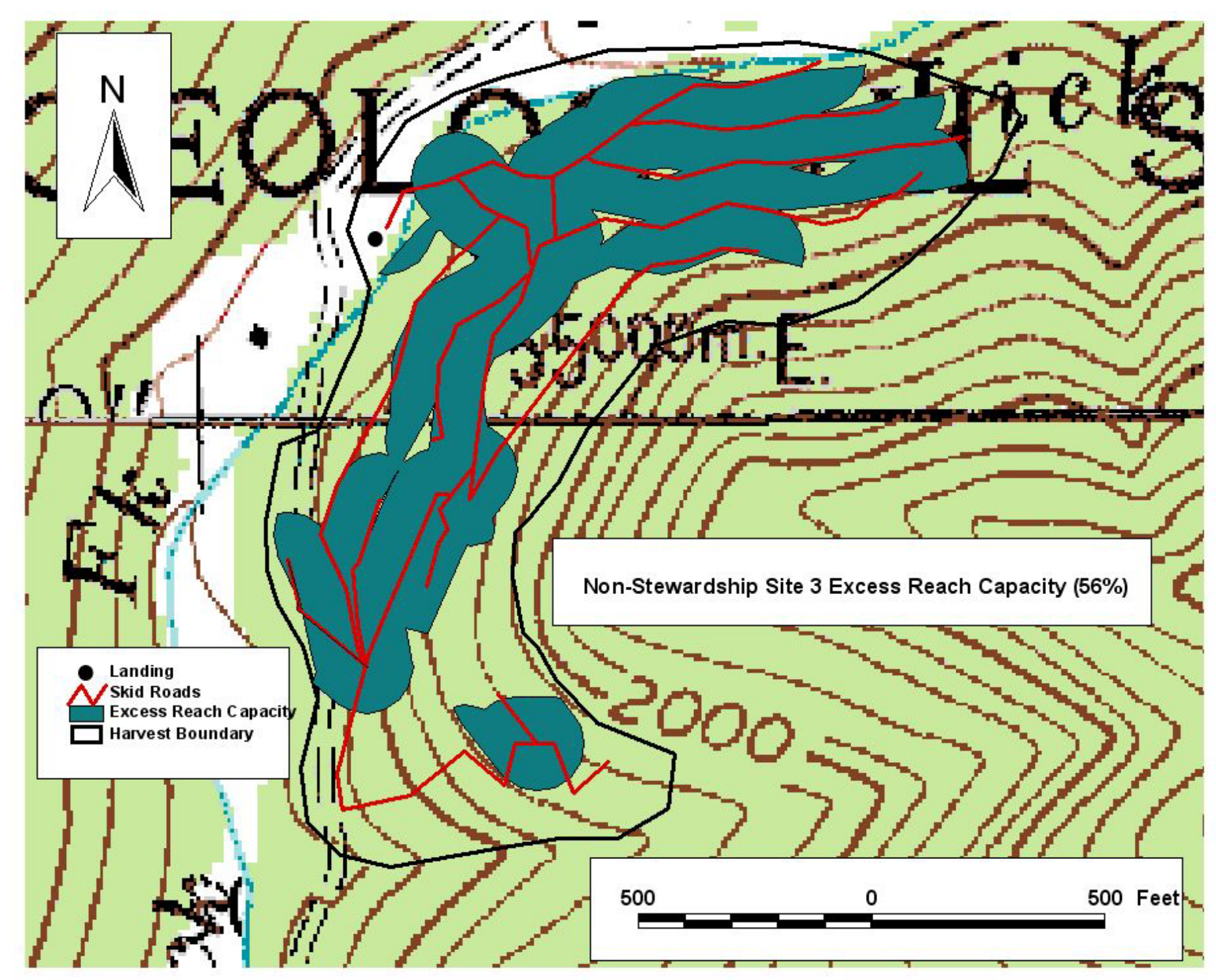




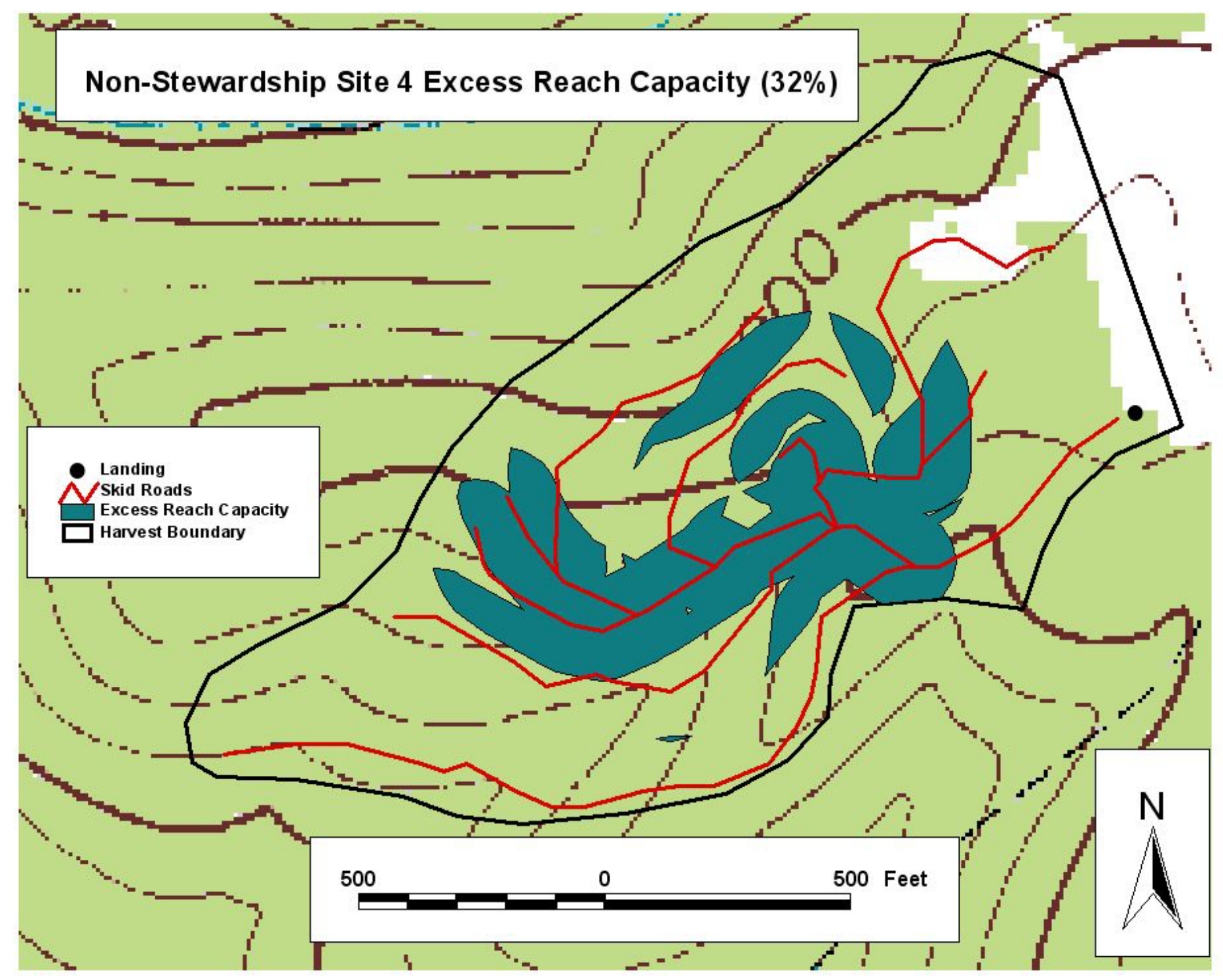




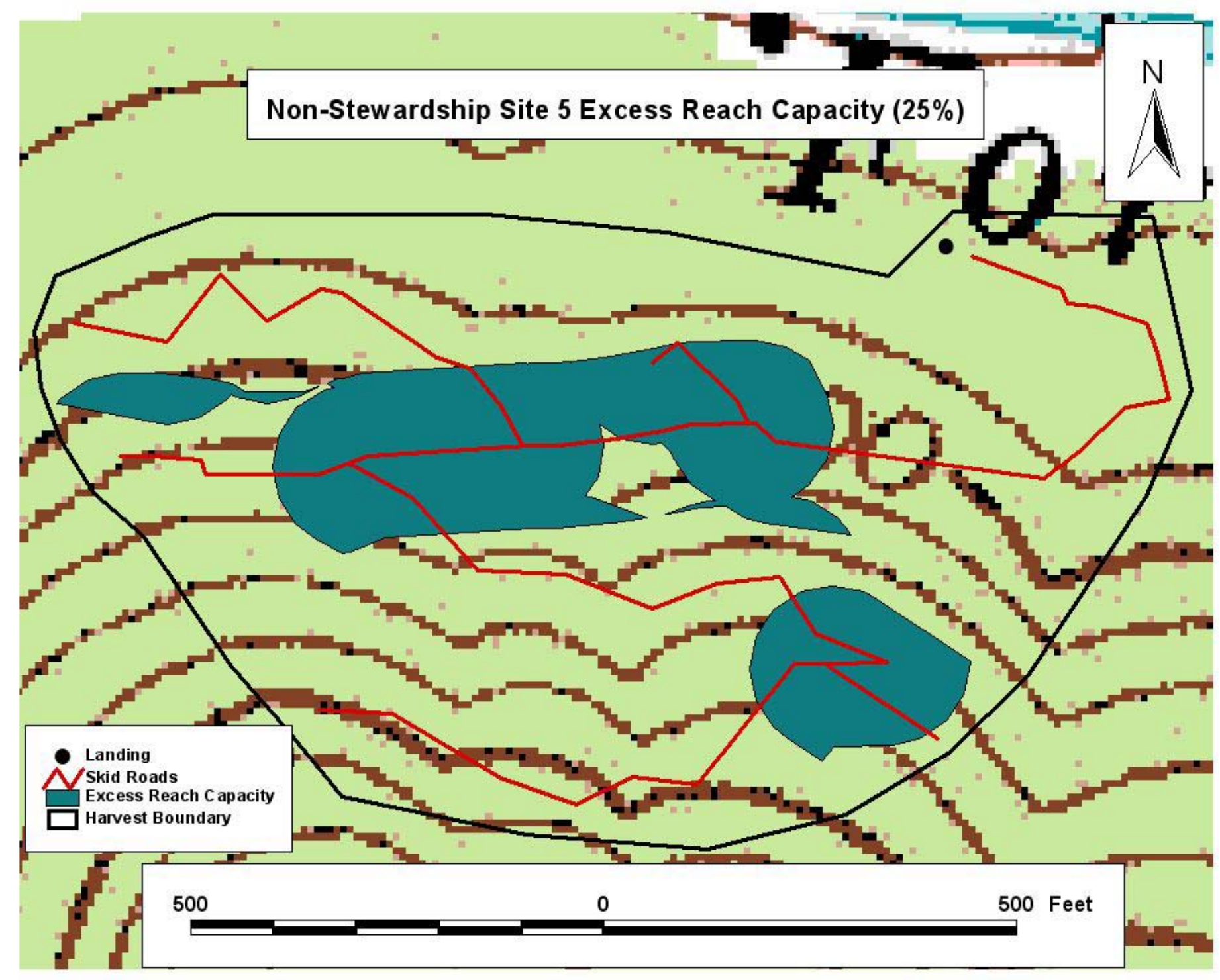




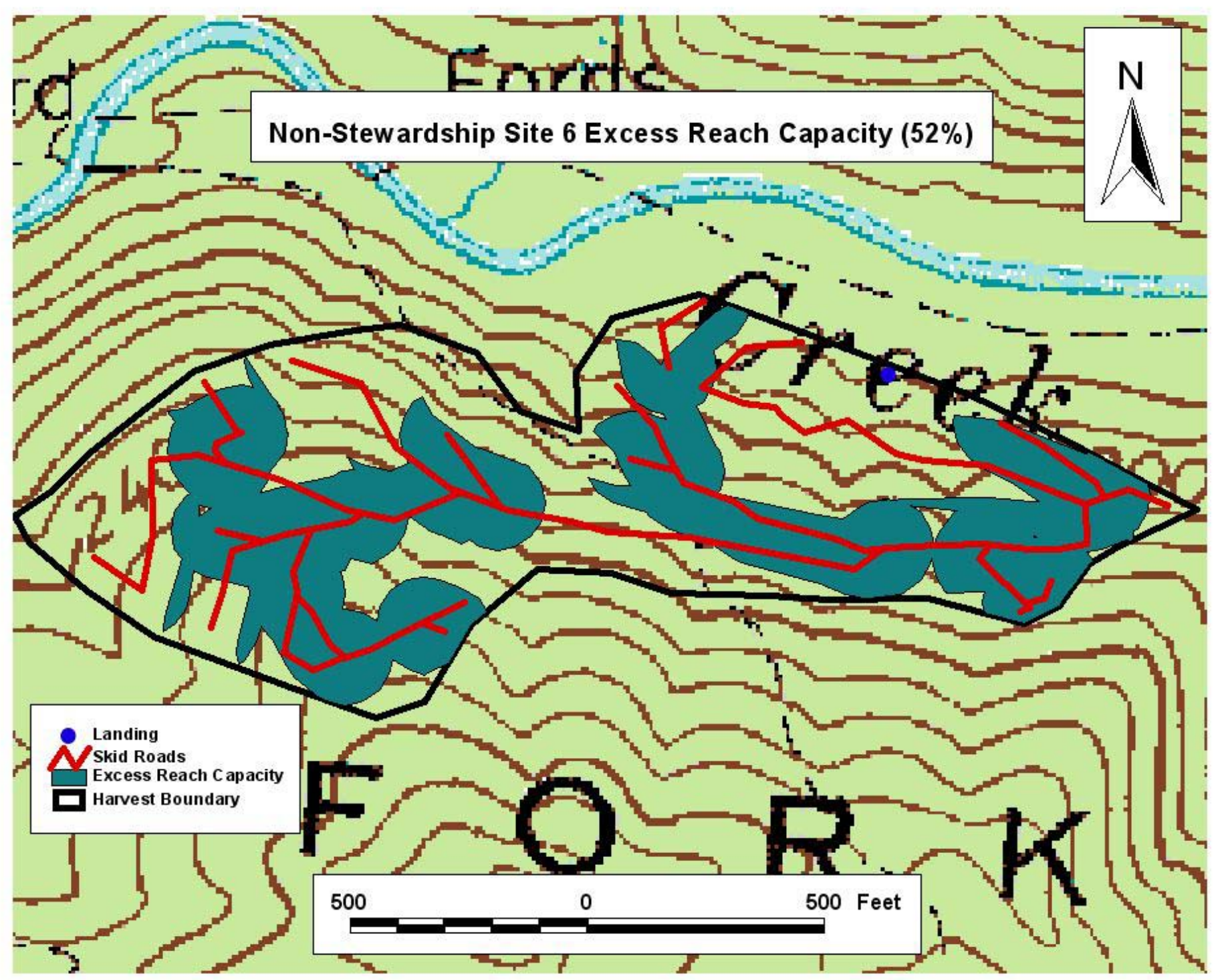




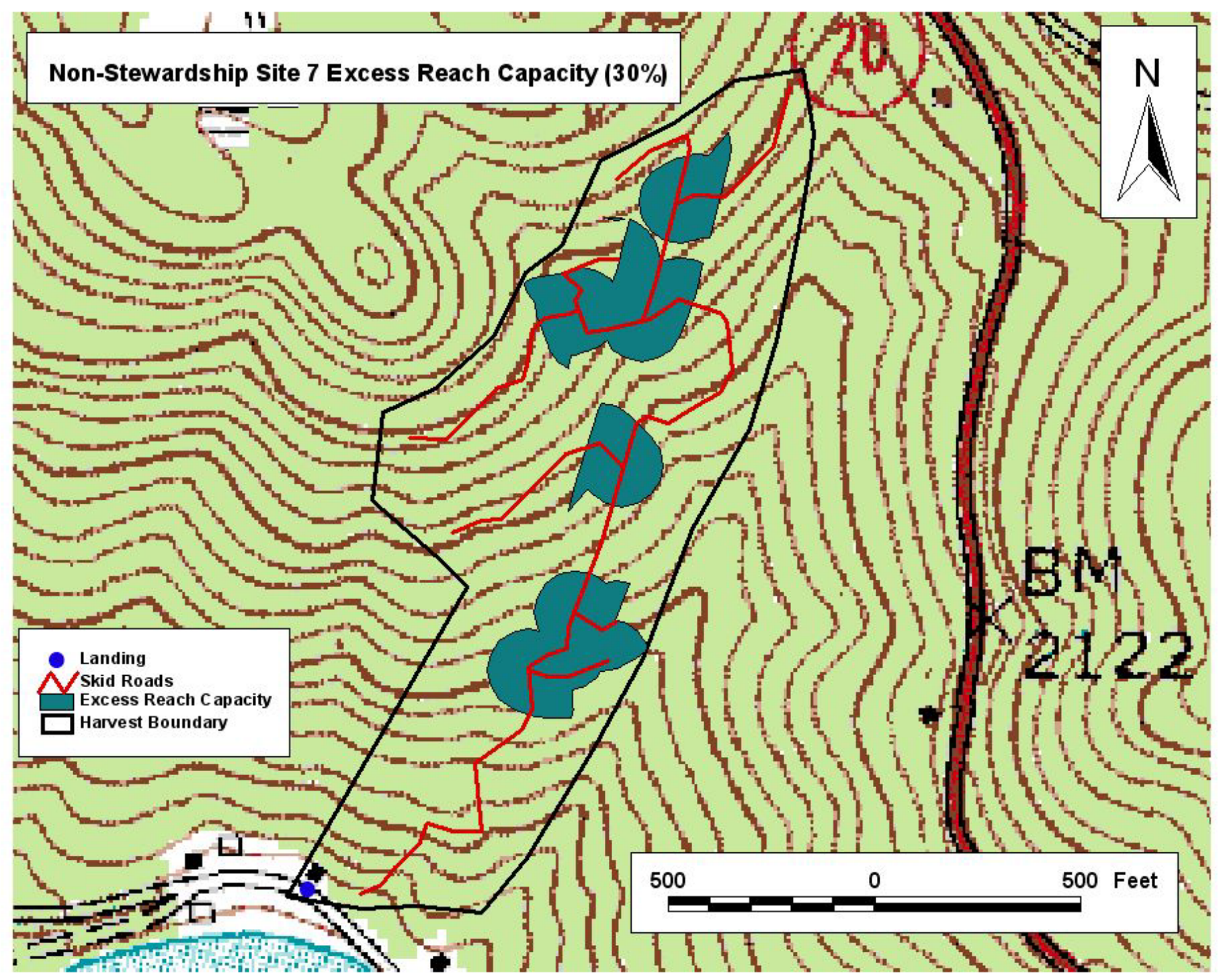




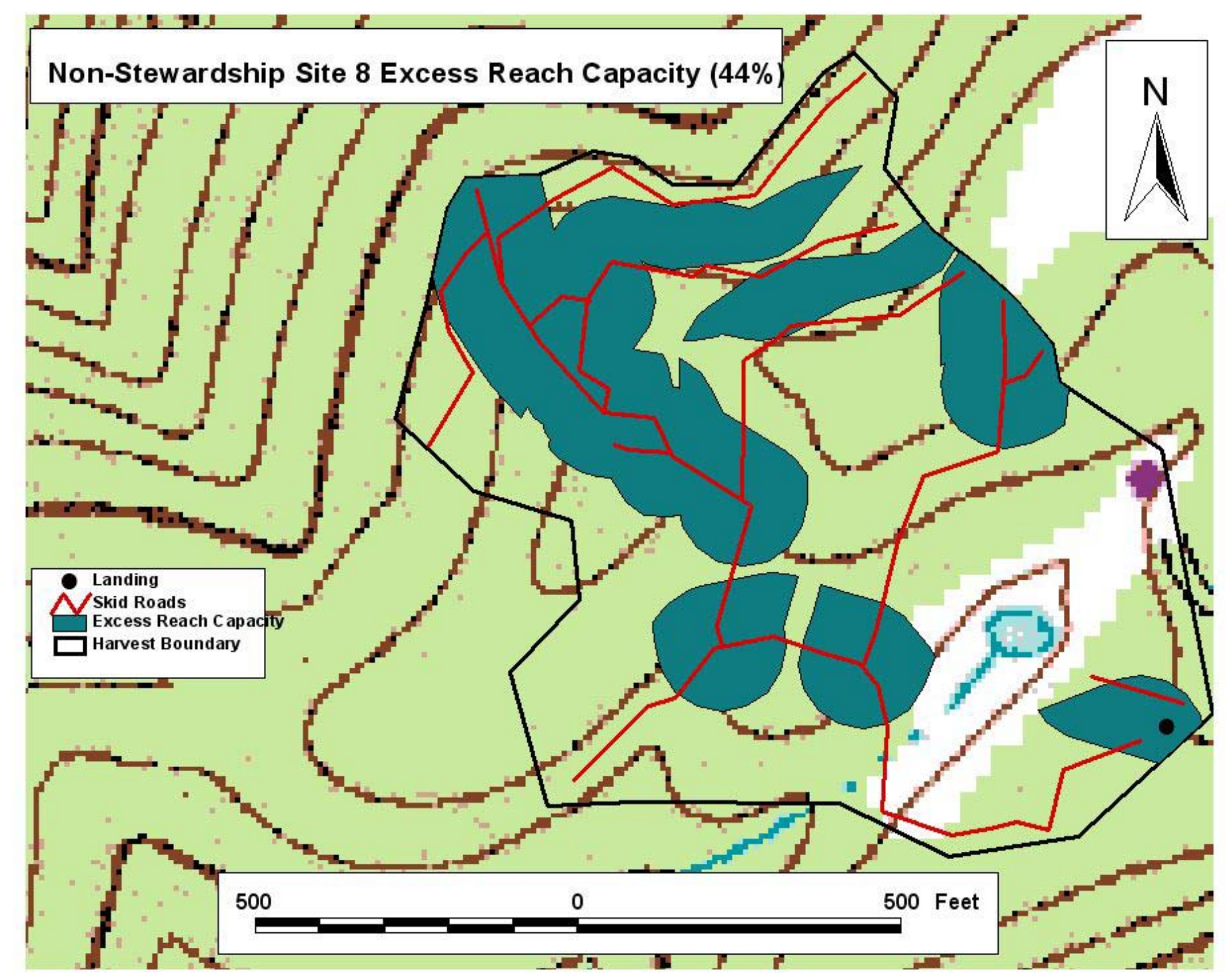




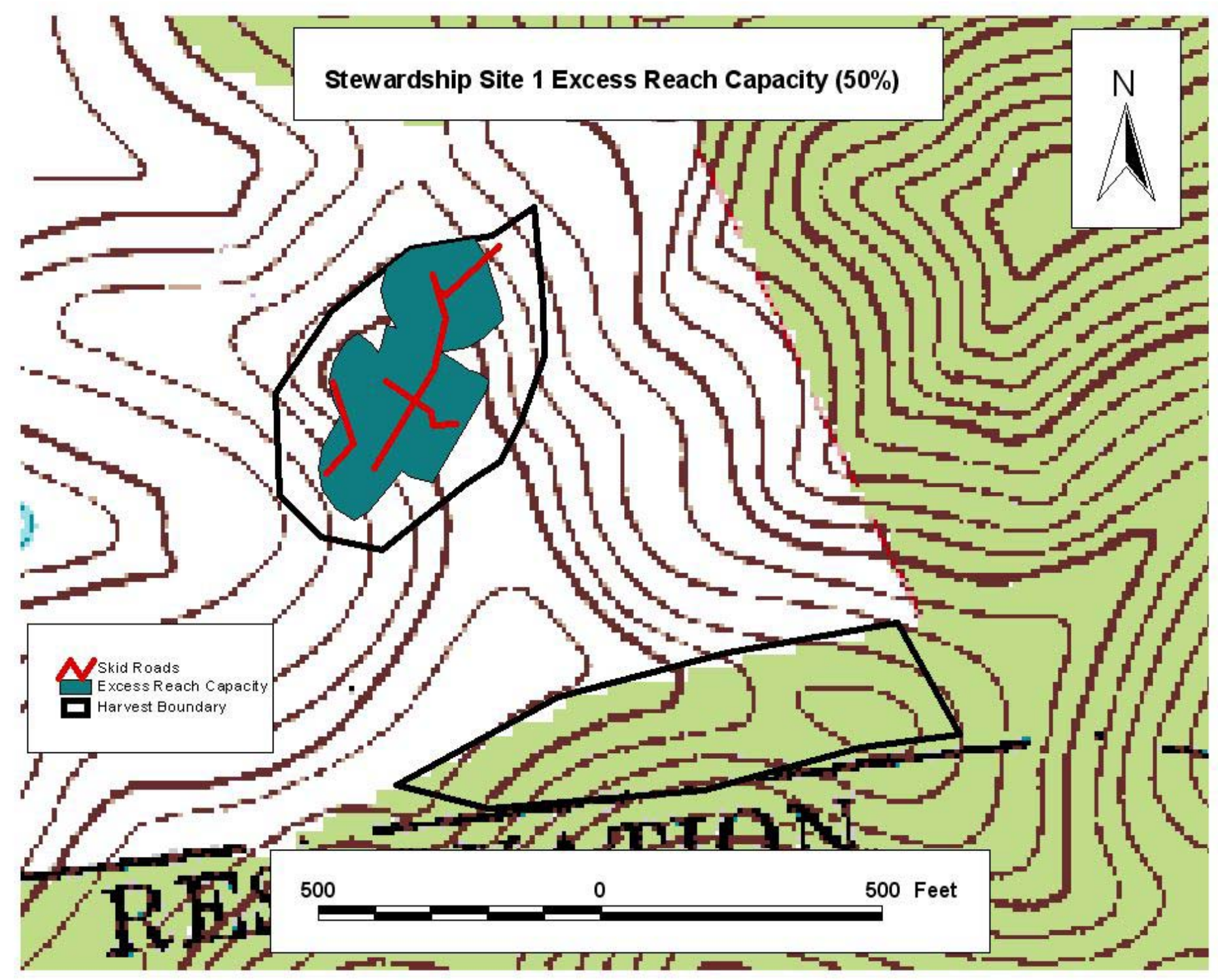




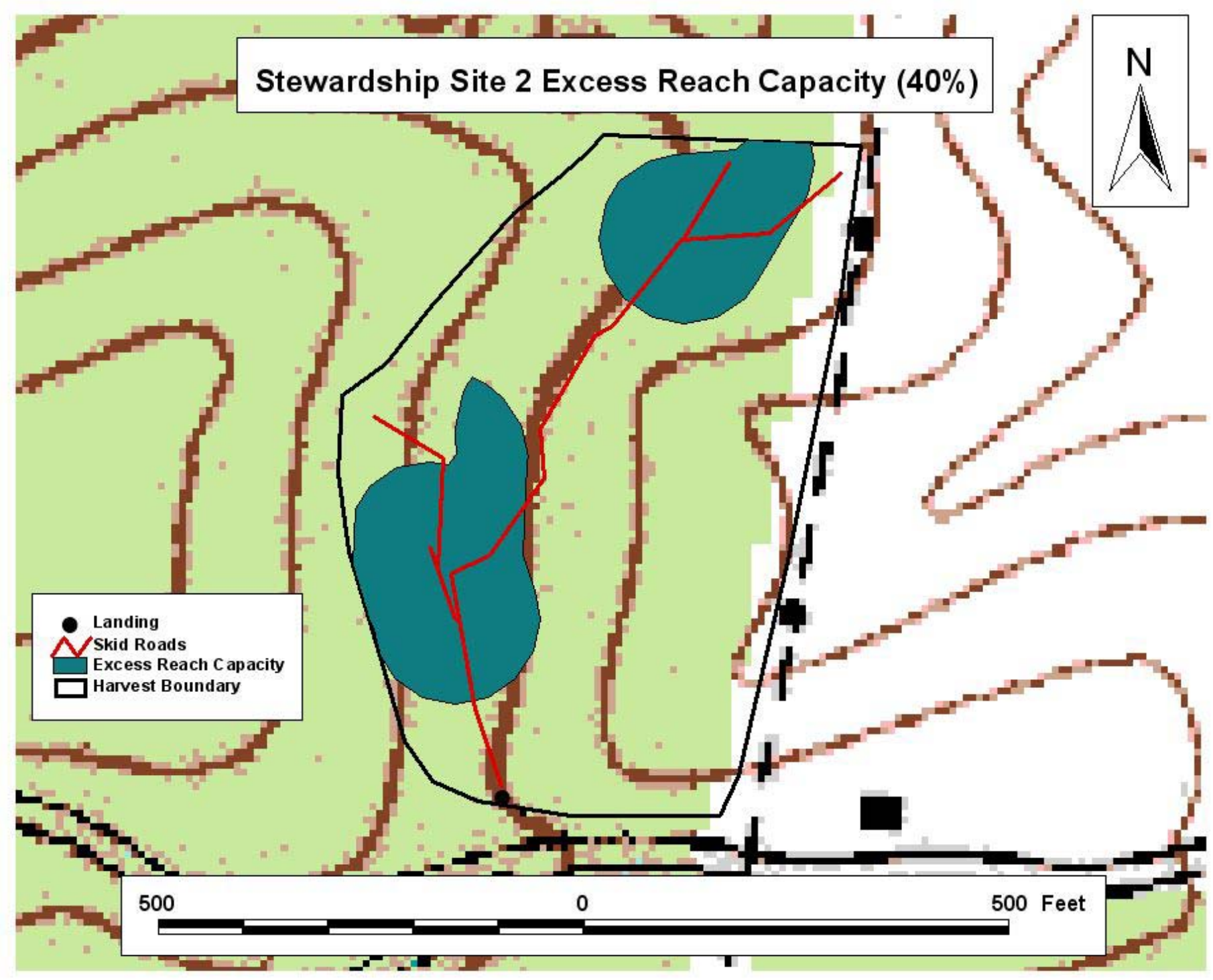




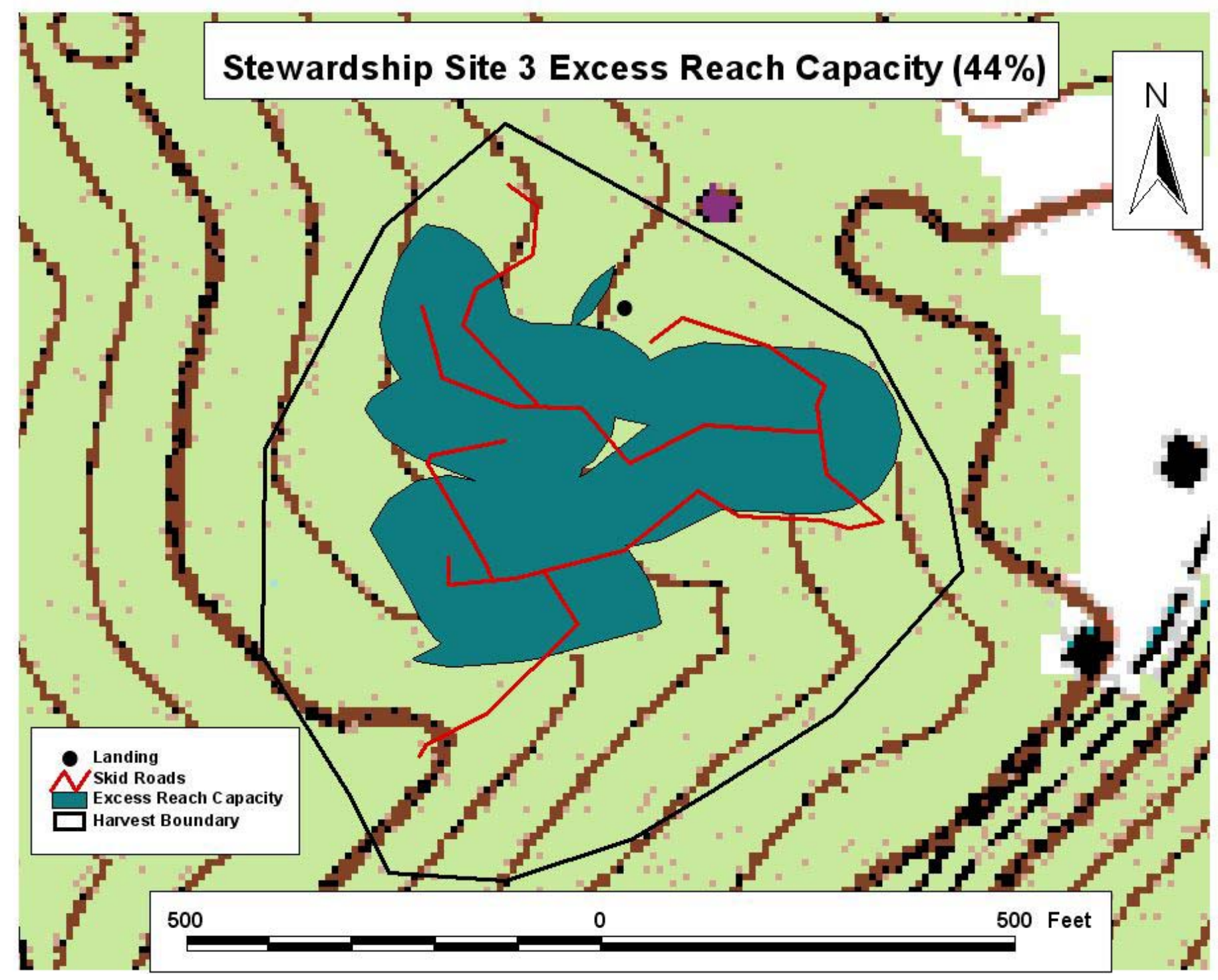




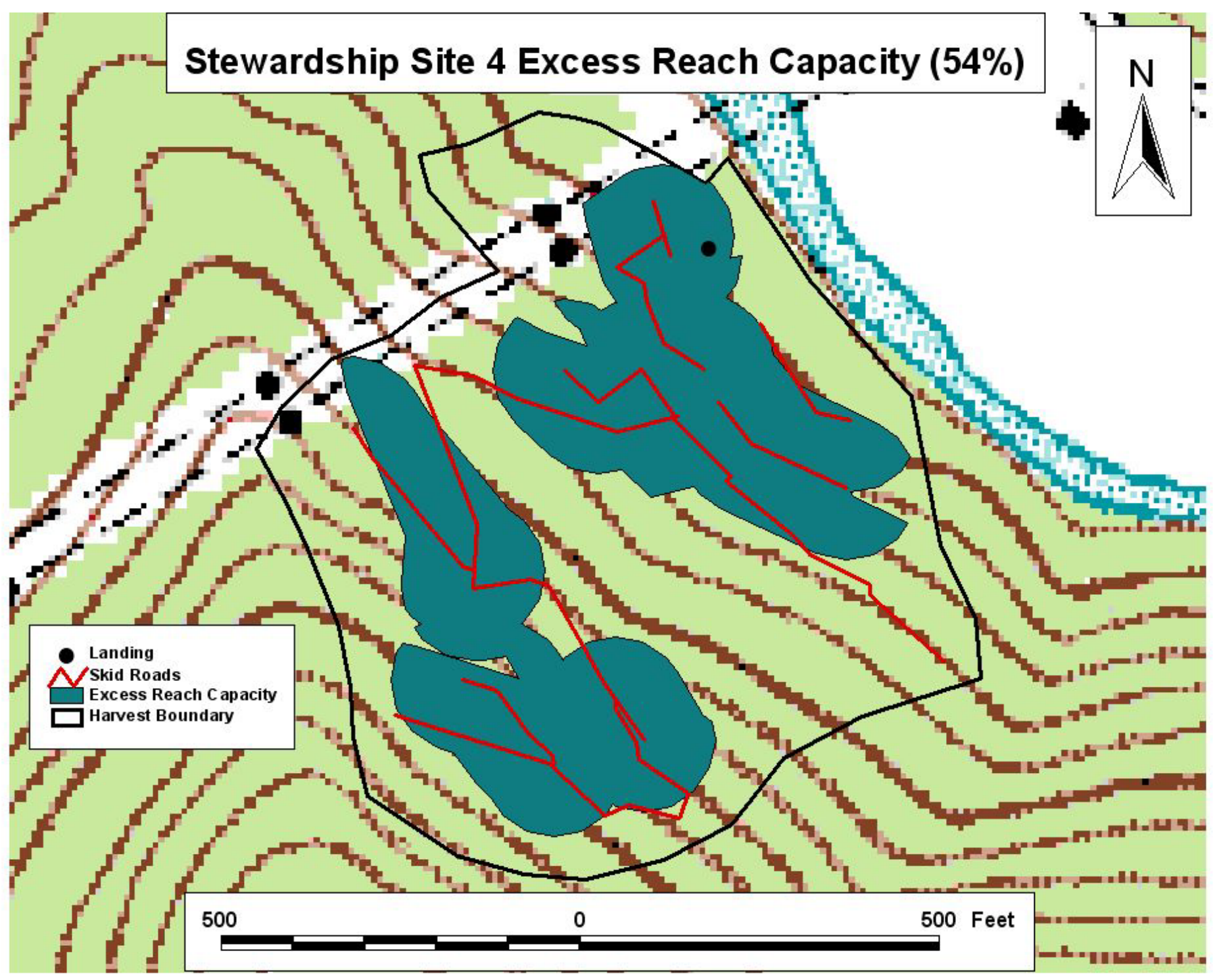




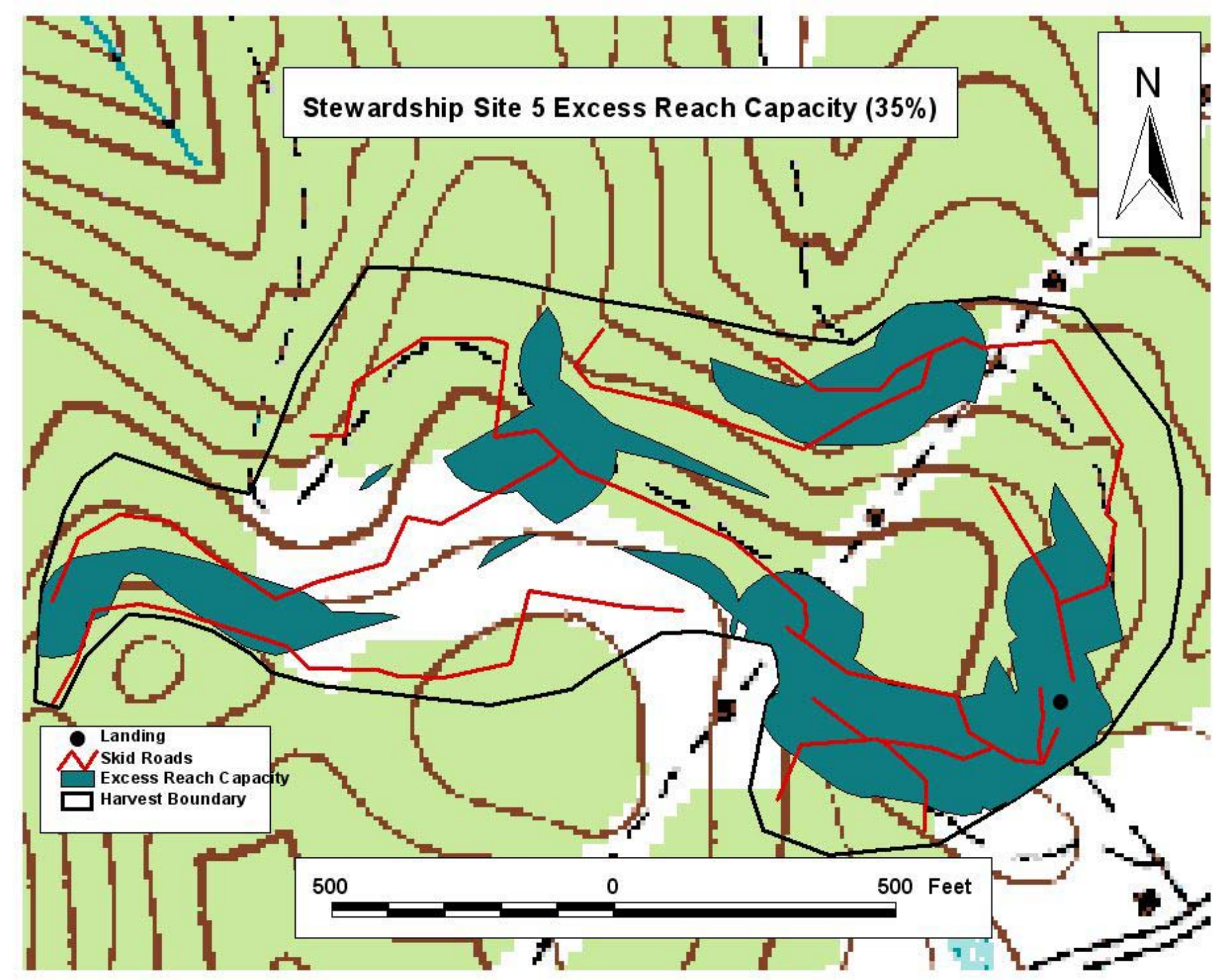




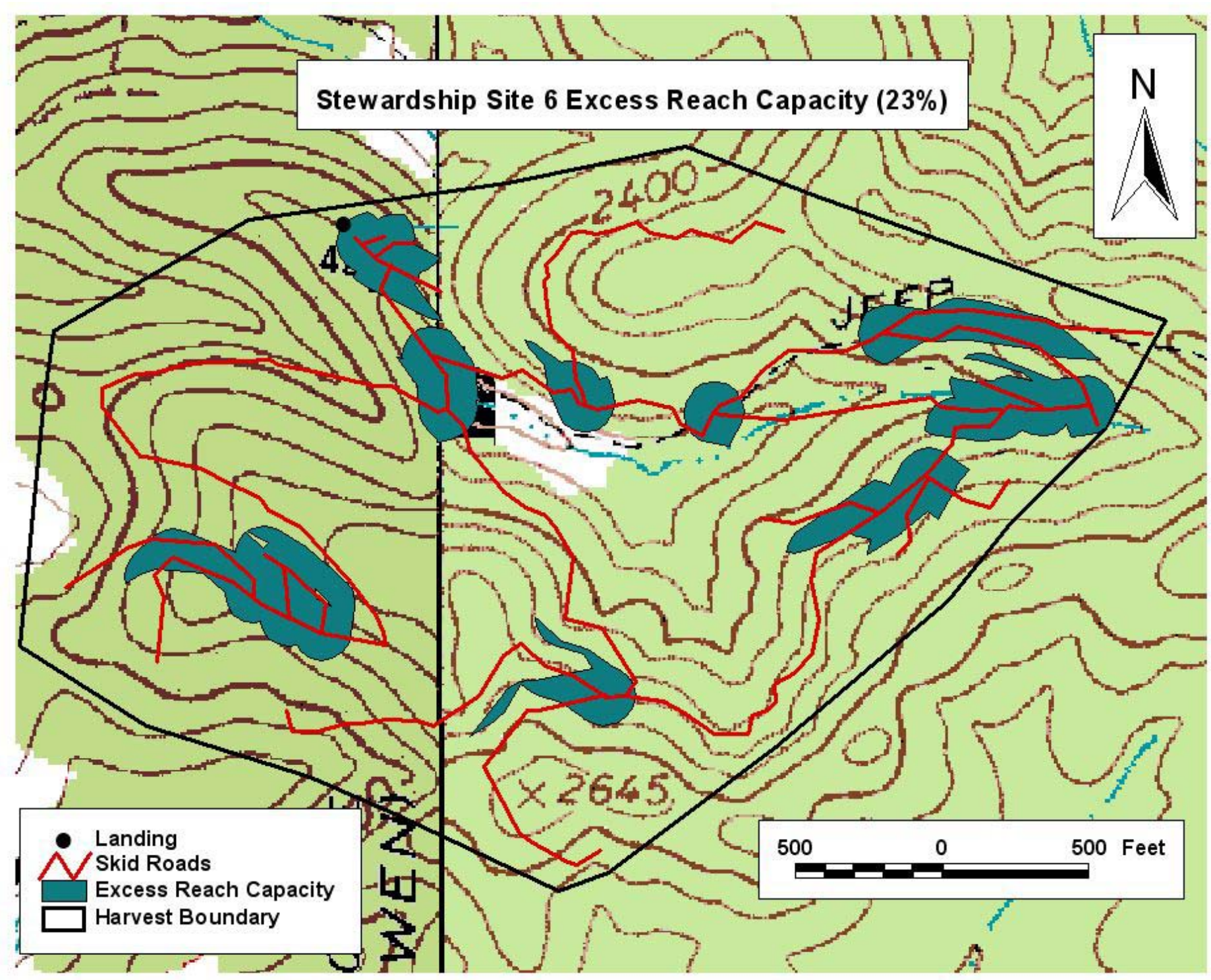









\section{Appendix D: Grade distribution graphs}
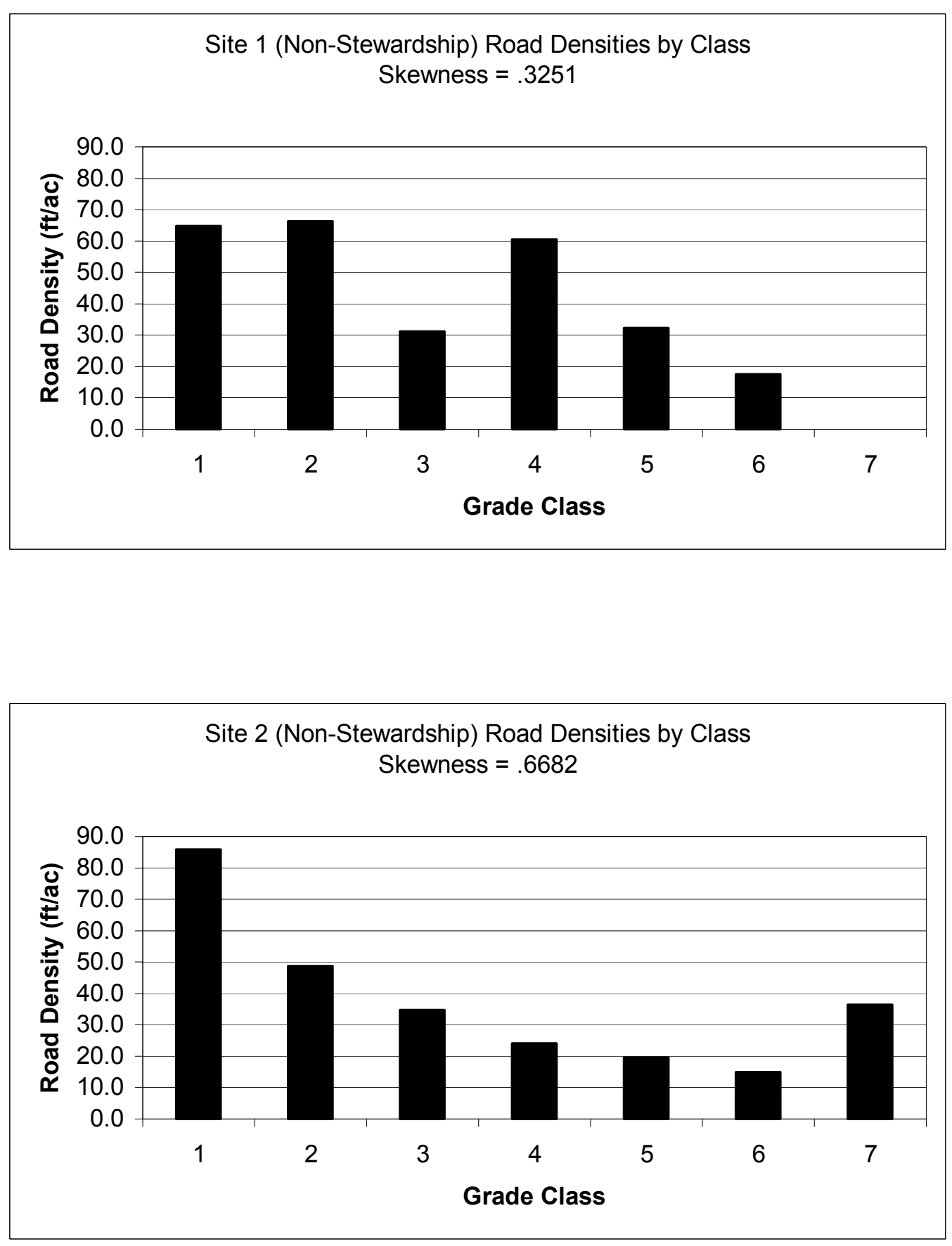

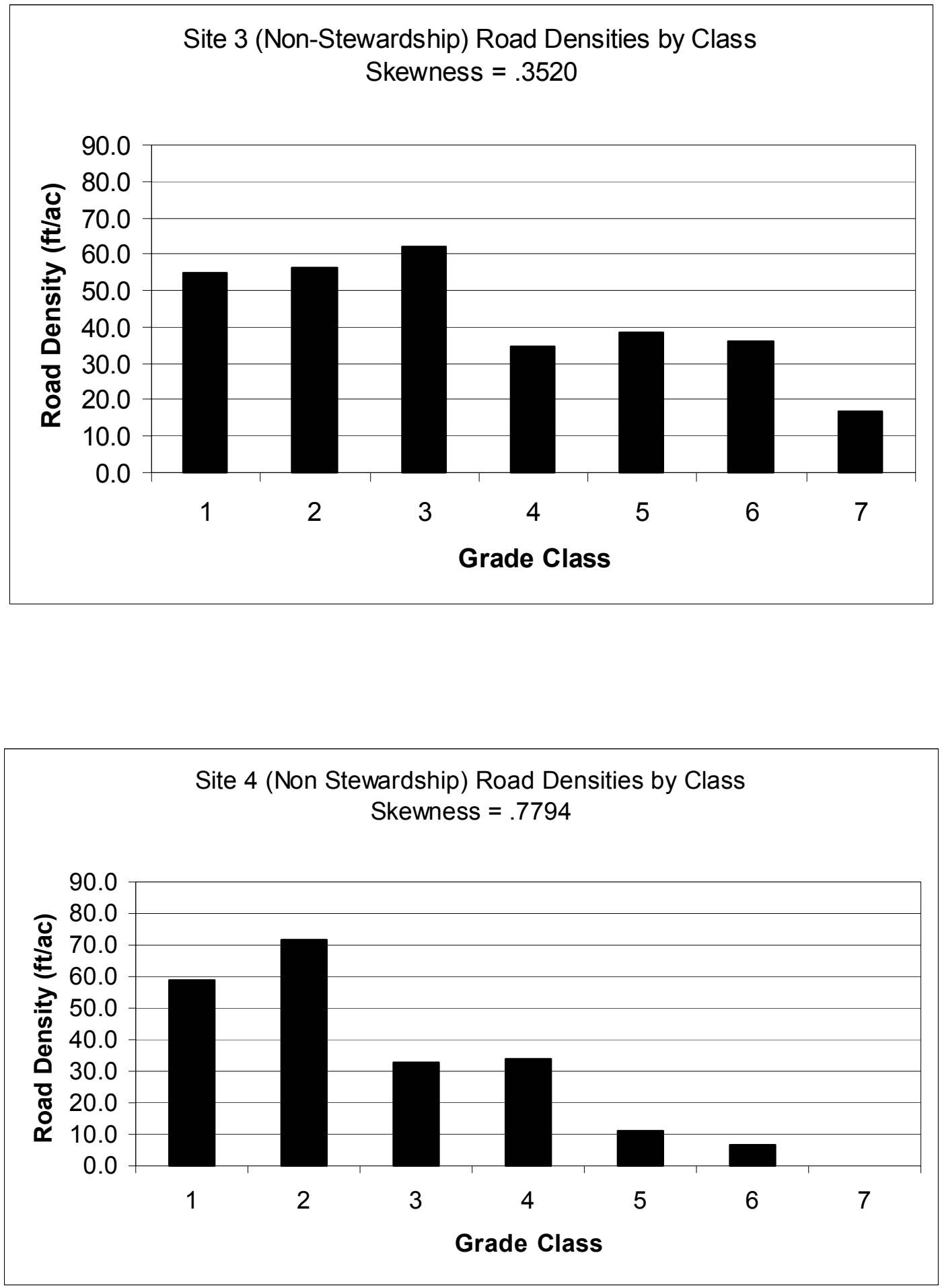

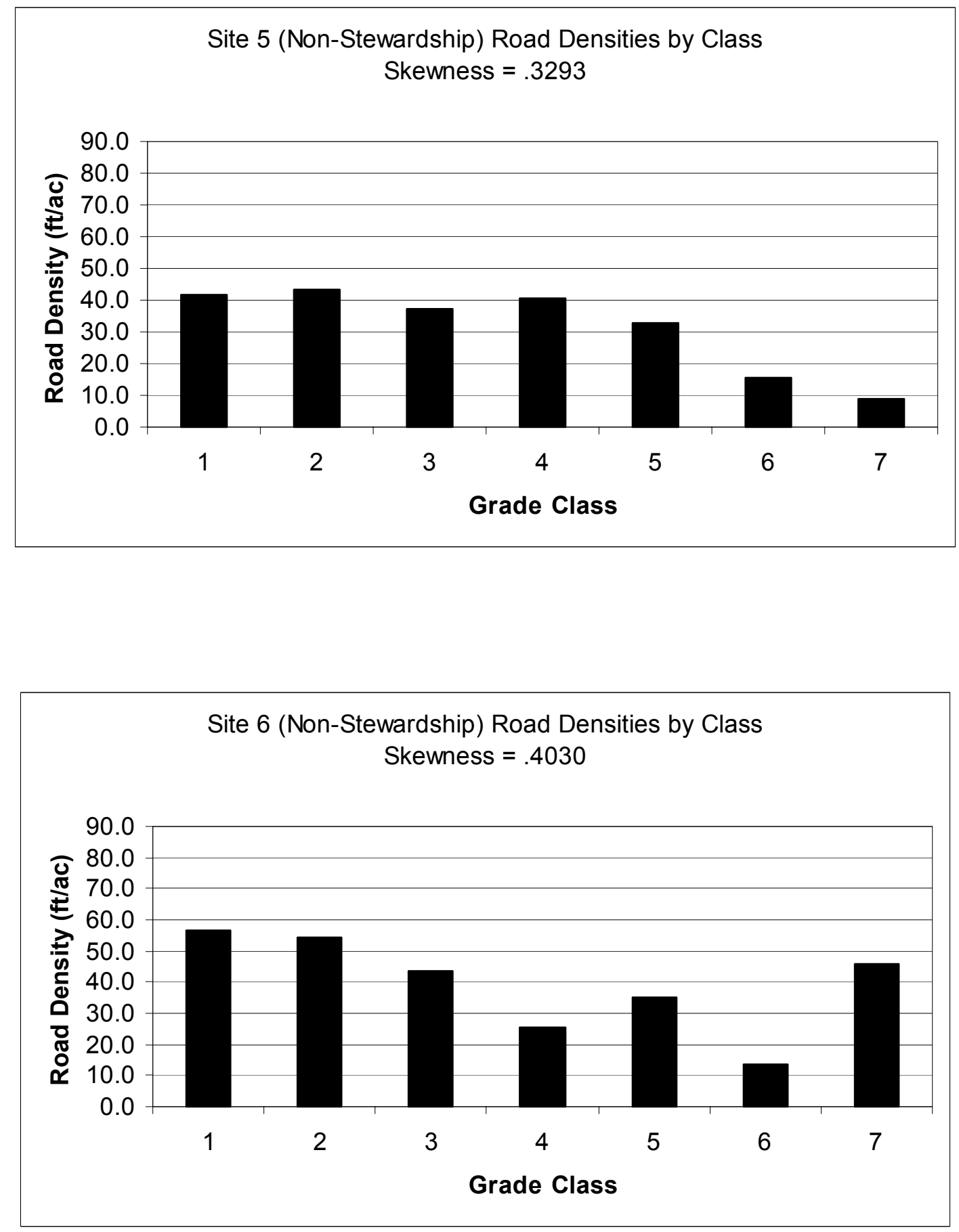

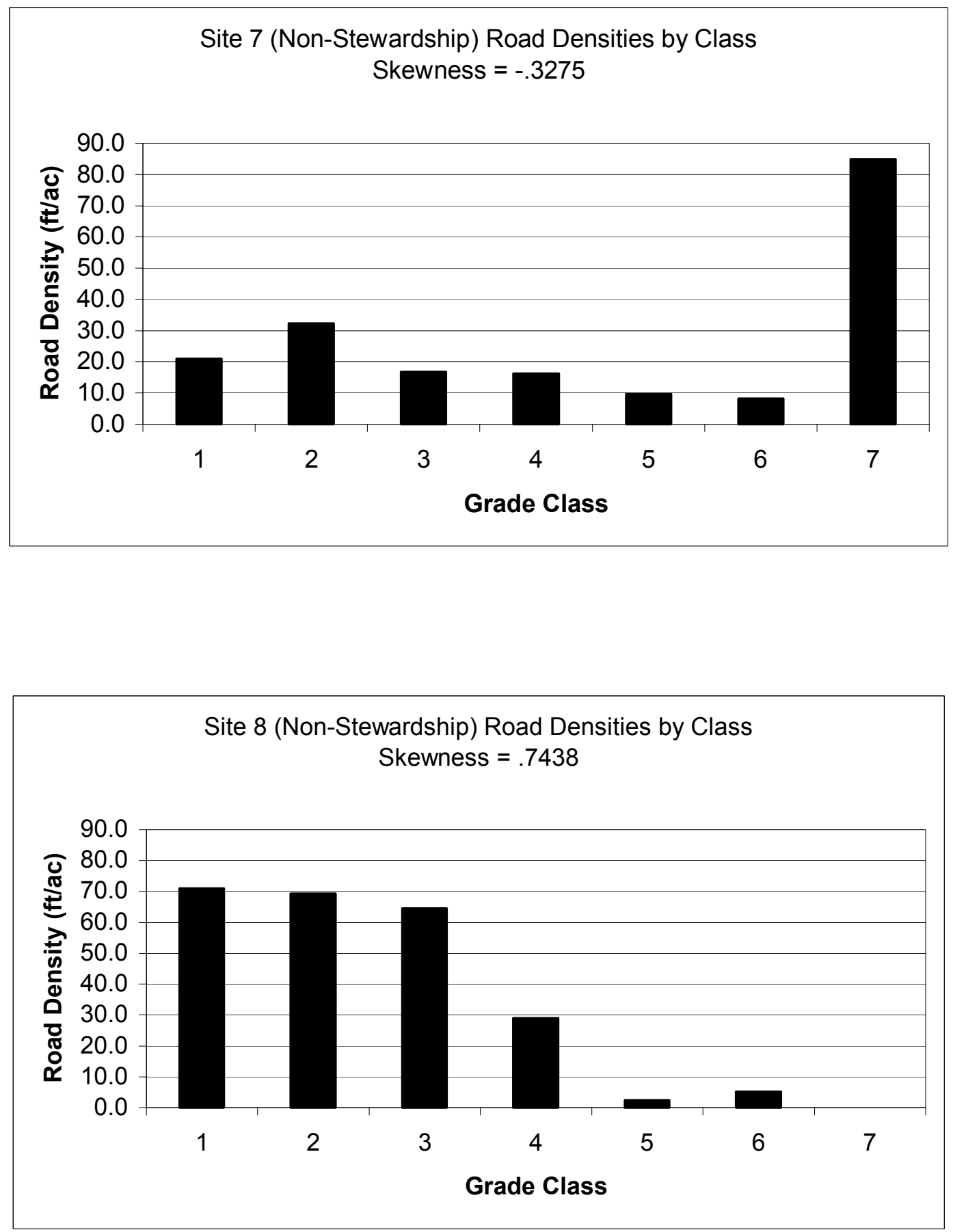

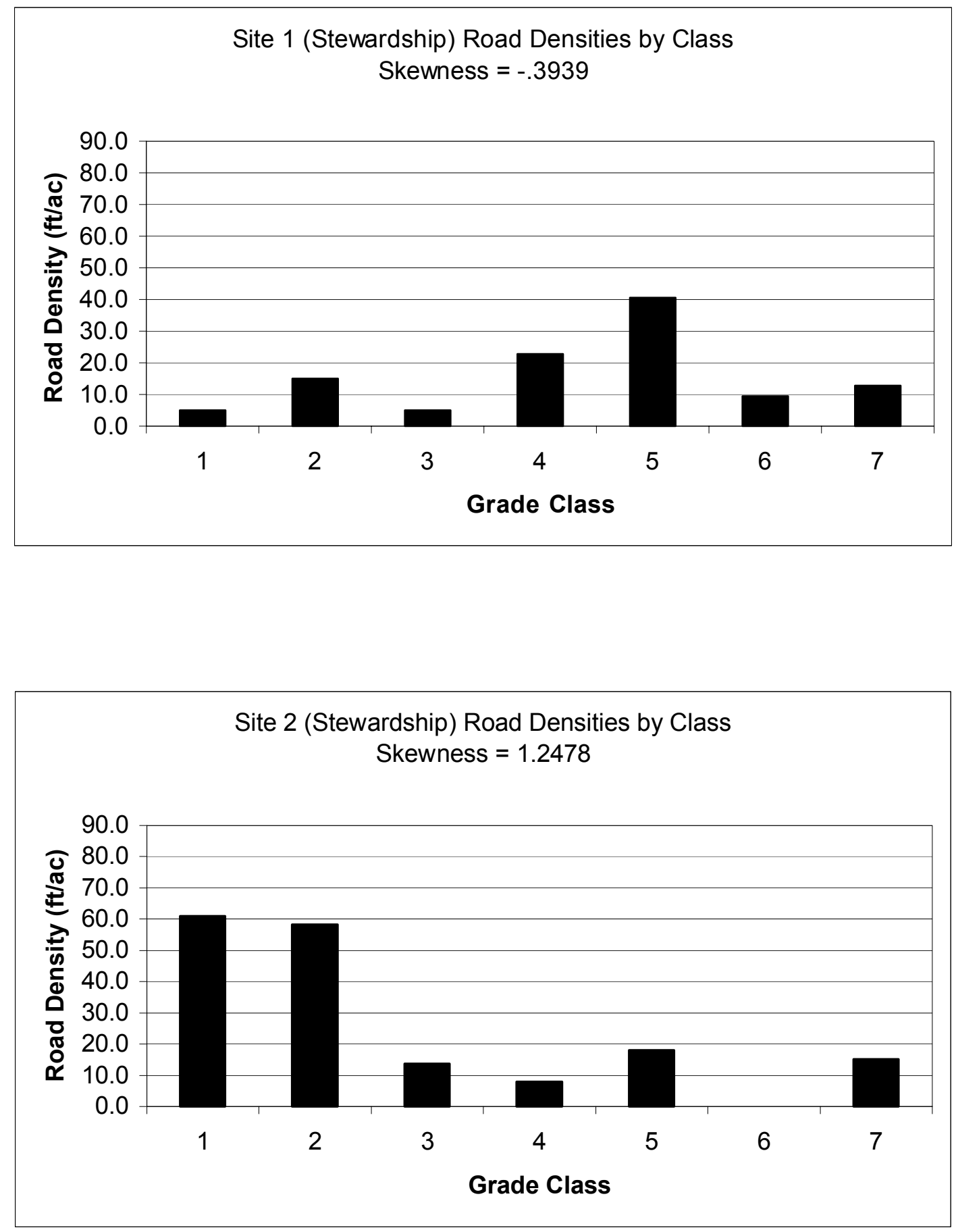

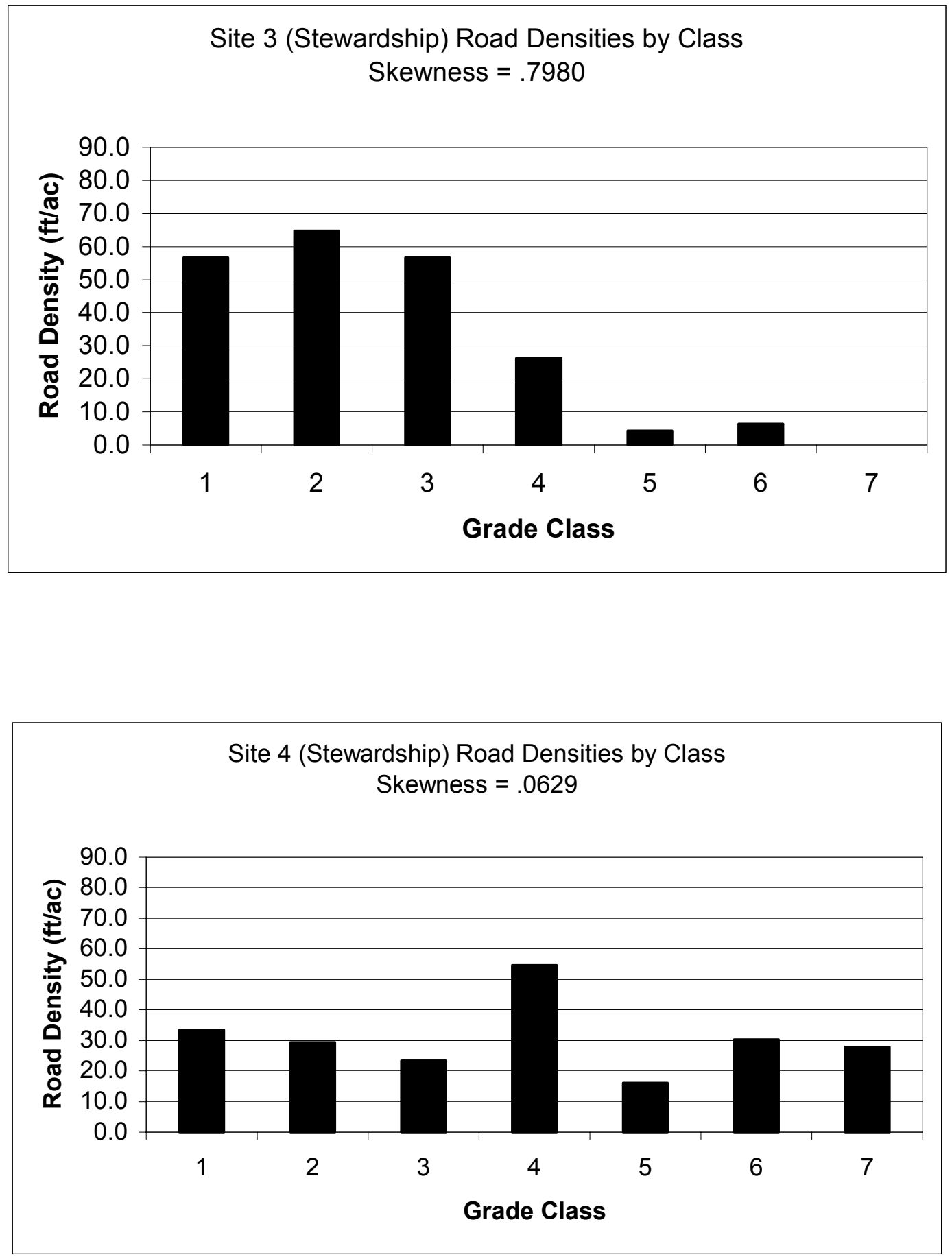

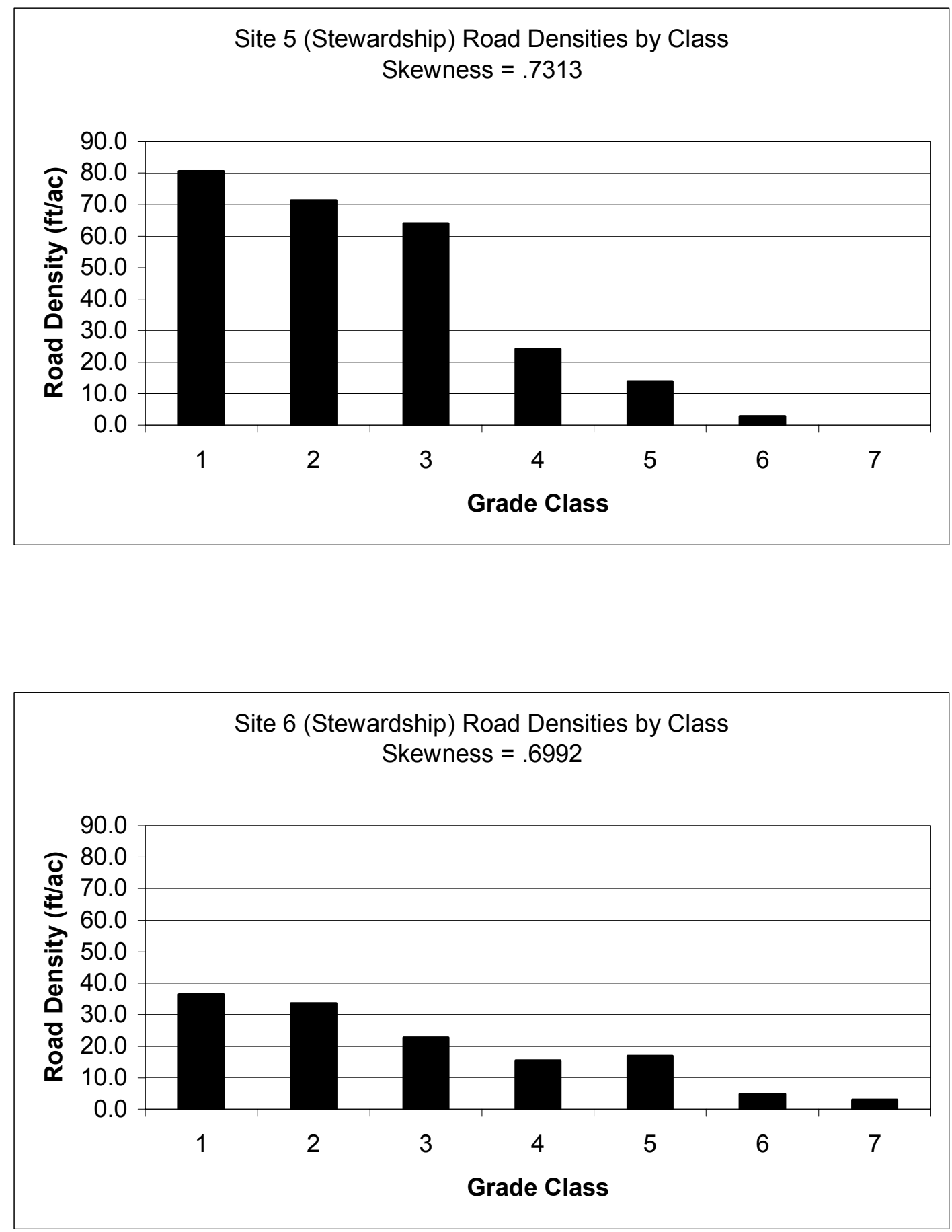


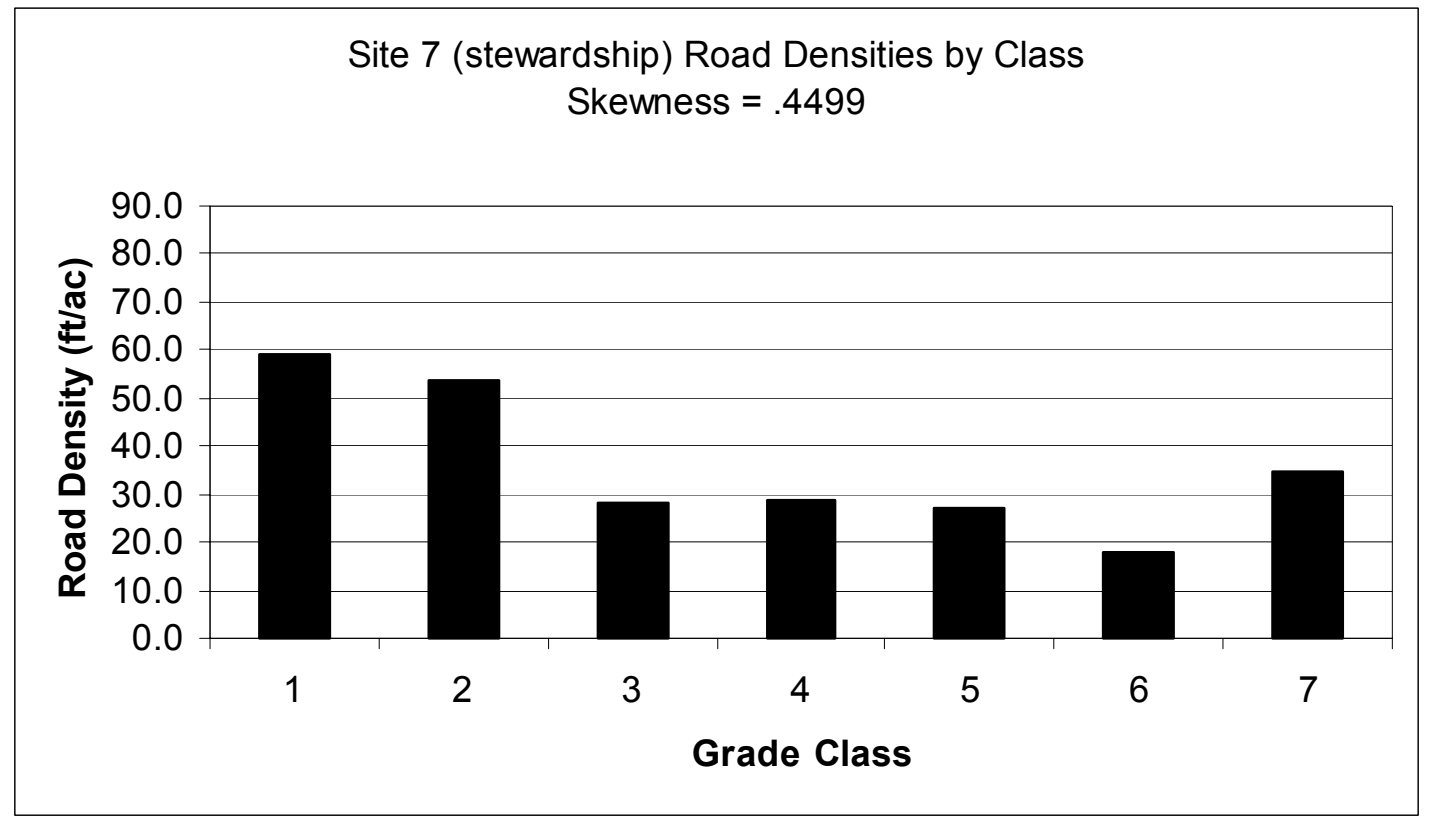

